4 norden 



\section{Virksomhedernes klagebehandling i Danmark og Sverige}


Virksomhedernes klagebehandling i Danmark og Sverige

TemaNord 2005:553

(C) Nordisk Ministerråd, København 2005

ISBN 92-893-1191-6

Tryk: Ekspressen Tryk \& Kopicenter

Layout: Publikationsenheden, NMR

Oplag: 120

Trykt på miljøvenligt papir som opfylder kravene i den nordiske miljøsvanemærkeordning.

Publikationen kan bestilles på www.norden.org/order. Flere publikationer på

www.norden.org/publikationer

Printed in Denmark

Nordisk Ministerråd

Store Strandstræde 18

1255 København $\mathrm{K}$

Telefon (+45) 33960200

Fax (+45) 33960202

www.norden.org

\section{Nordisk Råd}

Store Strandstræde 18

1255 København K

Telefon (+45) 33960400

Fax (+45) 33111870

\section{Det nordiske konsumentsamarbejde}

Samarbejdet i Nordisk Embedsmandskomité for Konsumentspørgsmål (NEK) har som mål at fremme forbrugernes sikkerhed, beskyttelse af økonomiske og retlige interesser, uddannelse og information og forbrugerindflydelse i samfundet. Informationsudveksling, udredninger og undersøgelser bidrager til en nordisk forbrugerpolitisk holdning og danner grundlag for fælles optræden i internationale sammenhænge.

\section{Det nordiske samarbejde}

Det nordiske samarbejde er et af de ældste og mest omfattende regionale samarbejder i verden. Det omfatter Danmark, Finland, Island, Norge og Sverige samt Færøerne, Grønland og Åland. Samarbejdet styrker samhørigheden mellem de nordiske lande med respekt for de nationale forskelle og ligheder. Det øger mulighederne for at hævde Nordens interesser i omverdenen og fremme det gode naboskab.

Samarbejdet blev formaliseret i 1952 med Nordisk Råds oprettelse som forum for parlamentarikerne og regeringerne i de nordiske lande. I 1962 underskrev de nordiske lande Helsingforsaftalen, som siden har været den grundlæggende ramme for det nordiske samarbejde. I 1971 blev Nordisk Ministerråd oprettet som det formelle forum til at varetage samarbejdet mellem de nordiske regeringer og de politiske ledelser i de selvstyrende områder, Færøerne, Grønland og Åland. 


\section{Indhold}

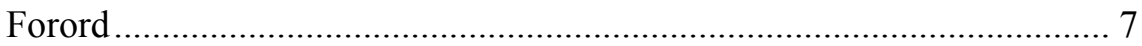

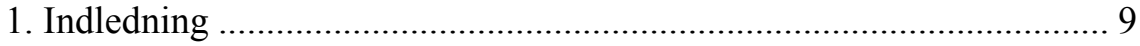

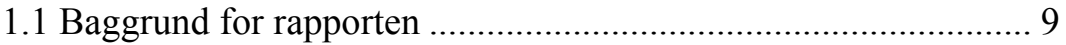

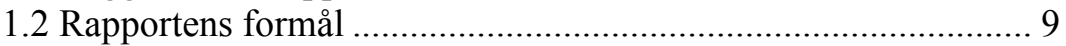

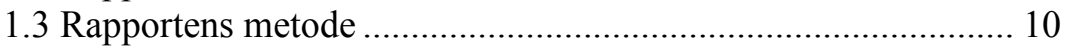

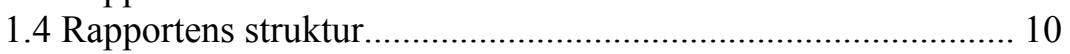

2. Forbrugerklager og klagebehandling............................................. 13

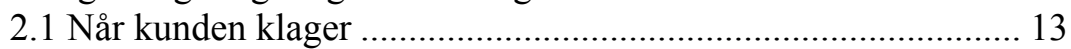

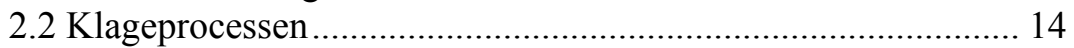

2.3 Kundens klagetilbøjelighed ..................................................... 15

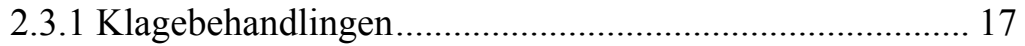

2.3.2 Klagebehandlingens hovedområder ................................ 19

2.4 Rapportens videre struktur........................................................ 20

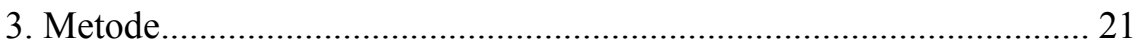

3.1 Udvælgelse af de undersøgte virksomheder ............................. 21

3.1.1 Deltagende virksomheder i undersøgelsen ....................... 22

3.2 Undersøgelsens reliabilitet og validitet ....................................... 23

4. Opfattelse af klagebehandling og kundeklager .................................... 27

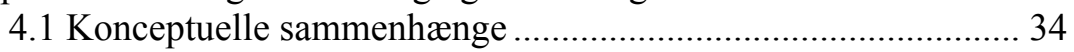

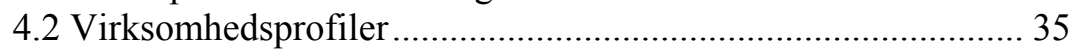

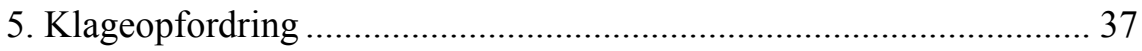

6. Klagebehandling og resultater af klagebehandling ............................ 41

7. Virksomhedernes forhold til lovgivning, ankenævn mv..................... 55

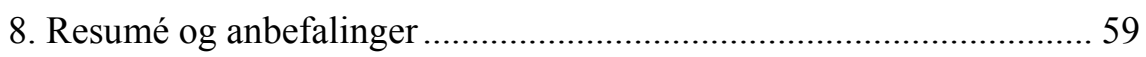

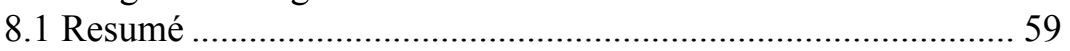

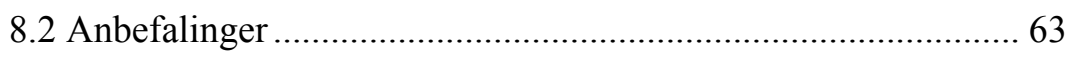

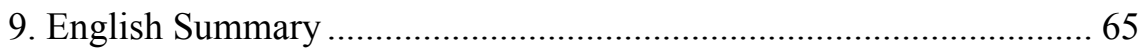

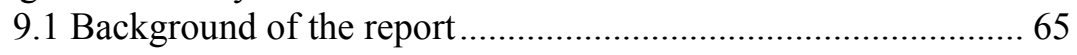

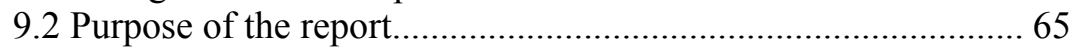

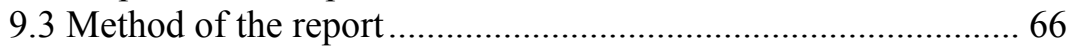

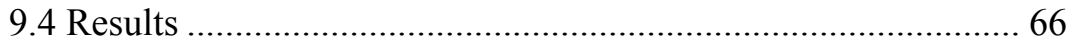

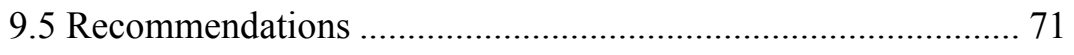

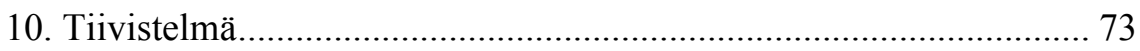

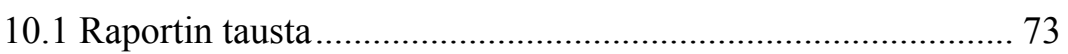

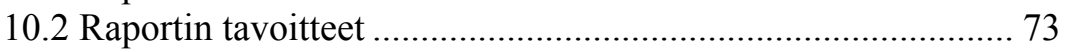

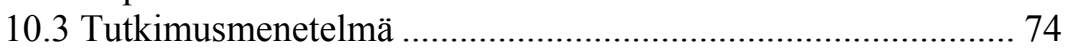

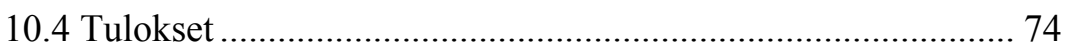

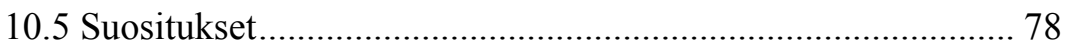




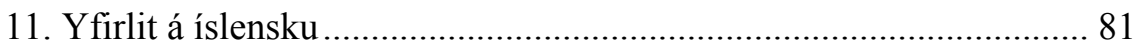

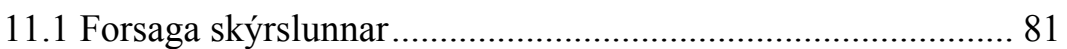

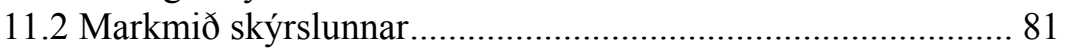

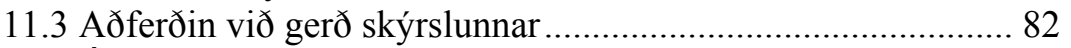

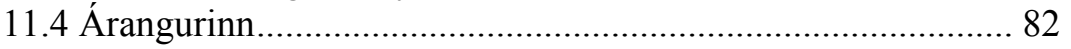

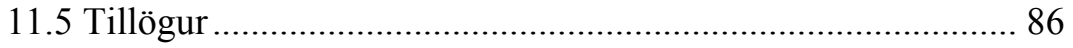

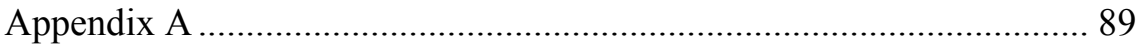

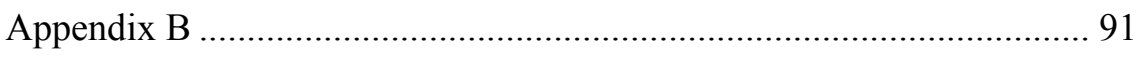




\section{Forord}

I denne rapport sigtes overordnet på at afklare udbredelsen og indholdet af nordiske virksomheders anvendelse af klagehåndteringssystemer og herunder de økonomiske effekter for virksomhederne af systematisk klagehåndtering. Rapporten omhandler således området 'complaint management'.

Rapporten er blevet til som et resultat af et udredningsarbejde foretaget for Nordisk Ministerråd med baggrund i et projekt, der blev påbegyndt og afsluttet i 2004. Rapporten sigter på at bidrage til udbredelsen af complaint management systemer i virksomheder og institutioner. Udbredelsen kan bidrage til en udvikling af nordiske virksomheders konkurrenceevne, der er i harmoni med forbrugernes interesser. Herved kan antallet af sager, hvor det offentlige må bidrage som konfliktløser mellem virksomheder og forbrugere forventeligt reduceres.

Kenneth Skov Jensen, Forbrugerstyrelsen, Danmark, har været projektleder, og Anita Hoffer, Forbrugerstyrelsen, Danmark har været projektkoordinator. Den nedsatte projektgruppe bestod af Marianne Kajander, Konsumentverket, Finland. Embla Einarsdóttir afløst af Eiríkur Áki Eggertsson, Neytendasamtökin, Island. Anita Dybdahl, Forbrukertvistutvalget, Norge. Eva Lindström, Konsumentverket, Sverige.

Rapporten er forfattet af institutleder Ricky Wilke, ph.d. og lektor Torben Hansen, ph.d. (begge fra Institut for Afsætningsøkonomi, Handelshøjskolen i København - Copenhagen Business School). Catinét Research (Danmark) har stået for dataindsamlingen.

Rapportens resultater er baserede på litteraturstudier af såvel videnskabelige artikler som manualer og standarder genfundet i branche eller offentligt regi, samt på en kvantitativ undersøgelse baseret på en onlinespørgeskemaundersøgelse blandt 4 brancher (møbler, dagligvarer, elektronik, biler) i to nordiske lande (Sverige og Danmark). I rapporten redegøres for eksisterende viden indenfor complaint management samt for konkrete resultater vedrørende danske og svenske virksomheders adfærd i forbindelse med complaint management. 



\section{Indledning}

\subsection{Baggrund for rapporten}

Denne rapport er udarbejdet på foranledning af Forbrugerstyrelsen i Danmark og er finansieret af Nordisk Ministerråd.

Baggrunden er at den offentlige sektor op igennem 1970'erne og til i dag har oplevet et stigende antal forbrugerklager over erhvervsdrivende. Dette er sket på trods af, at der fra offentlig side er anvendt mange ressourcer på etablere, udvikle og forbedre afgørelser mellem forbruger og erhvervsdrivende. Sådanne processer er også belastende for de erhvervsdrivende, som må anvende ressourcer i forbindelse med sådanne afgørelser.

Den offentlige sektor ønsker derfor at sætte fokus på yderligere et aspekt til at forbedre kontakten og dialogen imellem forbrugersiden og erhvervssiden, nemlig virksomhedernes egen klagehåndtering. Den offentlige sektor ønsker desuden bl.a. gennem dialog med virksomheder og brancher at kunne bidrage til at understøtte og fremme virksomhedernes ansvar for håndteringen af egne forbrugerklager, sådan at langt flere konflikter fremover kan løses direkte mellem den erhvervsdrivende og forbrugeren.

Projektet lægger således op til, at forbrugerpolitikken indarbejdes som en del af erhvervsudviklingen. Systematisk klagehåndtering i virksomheder er et initiativ, som både er til gavn for forbrugerne, der vil kunne opleve forbedret service og kvalitet, og for virksomhederne som vil kunne opleve et forbedret forhold til deres kunder.

\subsection{Rapportens formål}

Rapporten skal bidrage til, at forbrugermyndighederne opnår bedre indsigt $\mathrm{i}$ og viden om udbredelsen af og metoder til håndtering af forbrugerklager i virksomhederne, og dermed også opnår viden, som vil kunne danne udgangspunkt for mulige løsninger på håndteringen af det stigende antal forbrugerklager.

Konkret sigter denne rapport på at analysere, hvordan og i hvilken udstrækning nordiske (konkret er Sverige og Danmark valgt ud) virksomheder anvender klagehåndteringssystemer. Herunder sigtes blandt andet også på en indledende afklaring af forhold som virksomhedernes oplevede udbytte (f.eks. økonomisk) af at indføre klagehåndteringssystemer. 
Rapportens målgruppe er embedsmænd og politikere, der arbejder med fornyelse og forbedring af forbrugerpolitikken, samt virksomhedsledere og brancheorganisationer der ønsker at forbedre deres indsats for at styrke kundetilfredsheden.

\subsection{Rapportens metode}

Klagebehandling/klageledelse (eller 'complaint management') er en disciplin, som hidtil ikke har haft større videnskabelig fokus i Danmark. Årsagen kan være, at begrebet forveksles med 'klagemodtagelse og håndtering'/'complaint handling', en delmængde af 'complaint management', som isoleret set og umiddelbart synes at omfatte mere trivielle problemstillinger. Klagehåndtering beskæftiger sig med forhold som fysisk placering af eksempelvis klagebrevkasser, kundeinformation om klageprocedurer, kompensation med videre. Klagebehandling/-ledelse (complaint management) beskæftiger sig mere bredt med, hvorledes man udnytter klageinformation i kvalitetsudviklings- og konkurrencemæssig sammenhæng, blandt andet gennem implementering af en klageorienteret kultur i virksomheden. Denne rapports genstandsfelt er 'klagebehandling/-ledelse'.

Rapportens resultater er baserede på en kvantitativ undersøgelse baseret på online-spørgeskemaer af 4 brancher (møbler, dagligvarer, elektronik, biler) i to nordiske lande (Sverige og Danmark). Brancherne er valgt udfra hensynet til ønsket om en generel udbredelse af opmærksomheden på klagehåndteringssystemer blandt virksomheder i samfundet. Brancherne er desuden valgt ud fra, at disse tilsammen omhandler både kortog langvarige forbrugsgoder, lav- og højteknologiske forbrugsgoder samt høj- og lavprisfastsatte forbrugsgoder.

Det anvendte spørgeskema er baseret på studier af internationale teoretiske og empiriske undersøgelsesresultater indenfor området klagebehandling/-ledelse. Litteraturstudierne har både omfattet videnskabelige artikler og manualer og standarder genfundet i branche eller offentligt regi. Selvom teorifeltet stadig synes at være i et pre-paradigmatisk stadium, mener vi dog at have identificeret og anvendt relevante, adækvate og koncensusprægede dimensioner indenfor området.

\subsection{Rapportens struktur}

I kapitel 2 i denne rapport gives en introduktion til den viden, som i dag eksisterer vedrørende forbrugerens klageadfærd og virksomheders klagebehandling. Forståelsen af forbrugerens klageadfærd er første led i den samlede forståelse af virksomheders mulige klagebehandling. Således kan virksomhedens klagebehandling ikke indrettes isoleret uden skelen til 
efterspørgselssidens faktiske adfærd. Forbrugerens klageadfærd danner med andre ord den egentlig baggrundsstruktur for de aspekter af virksomhedens klagebehandling, som undersøges i denne rapport.

Kapitel 3 omhandler en redegørelse for undersøgelsens validitet (herunder repræsentativitet) og reliabilitet.

I kapitlerne 4-7 præsenteres undersøgelsens resultater i tabeloversigtsform med kommentarer.

Et resumé af rapporten samt anbefalinger på baggrund af rapportens resultater findes i kapitel 8, mens der i kapitel 9 gives et English Summary. 



\section{Forbrugerklager og klagebehandling}

\subsection{Når kunden klager}

En tilfreds kunde vil sjældent klage til den sælgende virksomhed over det modtagne produkt/den modtagne ydelse (hvor ikke andet er nævnt anvendes i det følgende blot betegnelsen 'vare' som samlebetegnelse for et produkt og en serviceydelse). Det betyder imidlertid ikke, at det helt kan udelukkes, at en sådan kunde alligevel vil kunne henvende sig til virksomheden med ros/ris, forslag til forbedringer mv., men det er undtagelsen. Den klagende kunde vil som regel være utilfreds med enten den pågældende vare, varens distribution, betalingsforhold og/eller den kommunikation, der er foregået imellem kunde og virksomhed.

Den utilfredse kunde følger ikke noget automatisk reaktionsmønster. De reaktioner, der fra kundens side måtte følge af en opstået utilfredshed kan være vidt forskellige fra kunde til kunde, fra vare til vare og fra situation til situation. Kunden kan desuden tænkes at have såvel tankemæssige (kognitive) som følelsesmæssige (affektive/emotionelle) reaktioner på utilfredsheden, ligesom utilfredsheden i sig selv også kan indeholde både tanke- og følelsesmæssige aspekter. Kunden vil også kunne se på, hvilken relevans og betydning den mangelfulde oplevelse udgør for ham/hende samt hvilke handlemuligheder, der set fra kundens side er til stede.

Grundlæggende står en række reaktioner/handlemuligheder åbne for kunden. Reaktionerne/handlemulighederne er ikke nødvendigvis hinanden gensidigt udelukkende. Kunden kan vælge at behandle sin utilfredshed ud fra et overvejende analytisk/tankemæssigt perspektiv og fokusere på selve problemet, samt hvorledes en eventuel klage praktisk planlægges og gennemføres. Kunden kan også vælge at forfølge en emotionel fokusering af sin utilfredshed, som kan føre til en forstærket følelsesmæssig reaktion (kunden kan blive rasende, f.eks. a la udsagnet "jo mere jeg tænker over det, jo mere rasende bliver jeg.."), eller kunden kan vende den følelsesmæssige reaktion indad og bebrejde sig selv (f.eks. som afspejlet $\mathrm{i}$ udsagnet: "jeg burde have vidst bedre..").

Også andre typer af emotionel fokusering kan tænkes, herunder bevarelse af selvkontrol, følelsesmæssig negligering og/eller fortrængning af problemet. Nogle kunder vil måske også mene, at det vil være godt at indhente social støtte i enten det private nærmiljø, i det sociale rum (f.eks. hos kolleger) og/eller i det offentlige rum. Det kan måske være for at nedsætte sin usikkerhed om sin reaktion (f.eks.: "er det rimeligt, at jeg er så rasende..") eller for at udnytte andres kompetencer (f.eks.: "bør en bil 
ruste efter fem år..?"). Hele dette samspil, som kan være ganske komplekst, fører ikke nødvendigvis til, at kunden vælge at klage. Kunden kan f.eks. vælge at undlade at forfølge sagen yderligere, at foretage genkøb til trods for den ubehagelige hændelse og/eller at klage til tredjepart (f.eks. forbrugerklagenævnet, andre former for ankenævn, medier mv.).

\subsection{Klageprocessen}

En kunde som bliver utilfreds oplever i større eller mindre omfang en mental ubalance (kognitiv dissonans), som kan føre til mere eller mindre vidtgående mentale processer. Der kan her skelnes imellem to typer af mentale processer, som vil kunne interagere med hinanden: (1) Den primoere mentale proces og (2) den sekundcere mentale proces.

Ad 1. Den primcere mentale proces: Den primære mentale proces omhandler kundens oplevelse af de selv-relaterede konsekvenser af en utilfredsstillende vare. Kunden vil kunne vurdere, hvor langt varen ligger fra hans/hendes bagvedliggende motivation for at købe varen (dvs. varens grad af målopfyldelse), hvor relevant og betydningsfuld målopfyldelsen er, samt hvor personlig relevant og betydningsfuld varen er for personen.

Ad 2. Den sekundcere mentale proces: Den sekundære mentale proces omhandler kundens vurdering af, hvilke reaktionsmuligheder der står til hans/hendes rådighed, samt kundens vurdering af med hvilken forventelig succes disse reaktionsmuligheder vil kunne udføres.

Samspillet imellem den primære og den sekundære mentale proces vil kunne give sig udslag i forskellige typer af mentale reaktioner hos kunden. I tilfælde, hvor der er tale om stærkt begrænsede (opfattede) reaktionsmuligheder samtidig med, at kunden lægger betydelig vægt på målopfyldelse (varen skal kunne indfri forventningerne og derved tilgodese motivationen for at købe varen), vil kunden kunne opleve en stressfølelse, som vil kunne føre til egentlig vrede, forargelse og/eller foragt. Om en sådan kunde faktisk klager påvirkes af en række yderligere faktorer (se nedenfor om 'kundens klagetilbøjelighed').

Er der omvendt tale om betydelig reaktionsmuligheder (f.eks. nem og bekvem klageadgang mv.) kombineret med, at varekøbet kun er af minimal betydning for kunden, vil denne måske anse klagemuligheden, eller henvendelse til venner og bekendte mv., for irrelevant og ikke for værende 'besværet værd'. I sådanne tilfælde vil kun begrænsede mentale reaktioner udløses. Kunden vil desuden her kunne vælge at genkøbe varen senere (hvis problemet er irrelevant) eller blot købe en anden tilsvarende vare (f.eks. i tilfælde hvor kunden ikke har etableret faste præferencer for en bestemt type vare, eller hvor kunden ikke anser forskellene imellem de forskellige udbudte varer for betydende). I stadig andre tilfælde vil kunden måske opleve målopfyldelsen som betydningsfuld samtidig med, at kunden oplever, at det er nemt og bekvemt at klage. En sådan kunde vil 
mest sandsynligt vælge at klage til virksomheden. Men hvor vidt en kunde faktisk klager påvirkes desuden af en række faktorer, som vi senere skal se i afsnittet om 'kundens klagetilbøjelighed'.

I figur 2.1 er systematiseret den proces, der for forbrugeren kan lede frem til forskellige typer af reaktioner, som en kunde vil kunne tænkes at have på baggrund af sin utilfredshed. Det er her vigtigt at bemærke, at de forskellige typer af reaktioner ikke nødvendigvis er hinanden gensidigt udelukkende. Den utilfredse kunde kan f.eks. vælge både at søge social støtte og derefter klage til virksomheden. Eller man kan forstille sig, at kunden vælger både at boycotte virksomheden, rette henvendelse til massemedierne samt at udstille 'sagen' på internettet.

Figur 2.1. Klassifikation af reaktioner på baggrund af utilfredshed ${ }^{1}$

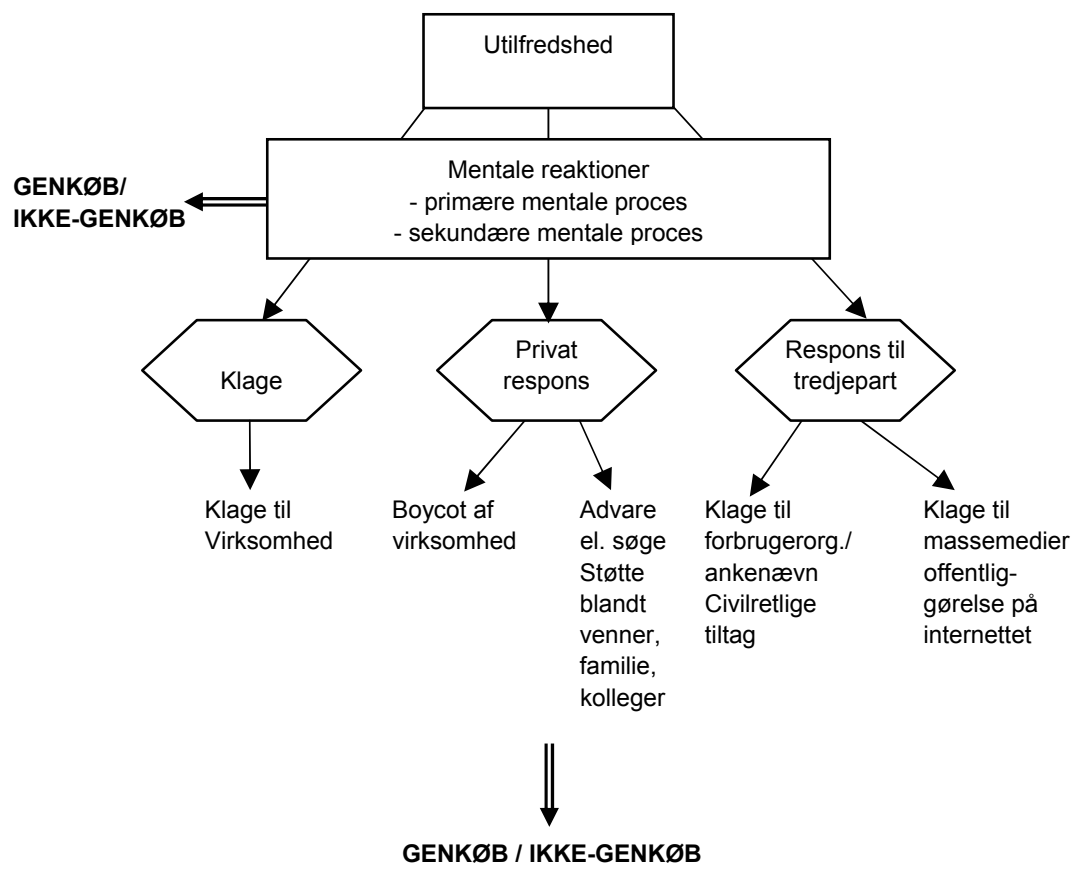

\subsection{Kundens klagetilbøjelighed}

Selvom det set fra virksomhedens side kan være fristende at glæde sig over manglende klager, så er det ikke sikkert, at det skyldes, at kunderne er tilfredse. En utilfreds kunde, som måtte vælge ikke at klage til virksomheden, kan af flere årsager fremstå et problem for virksomheden. (1) Virksomheden mister muligheden for kommunikere med kunden og evt. udbedre problemet og dermed øge muligheden for fastholde kunden. (2)

\footnotetext{
${ }^{1}$ Figuren er inspireret af dels Day, R.L. \& E.L. London (1977), Towards a Theory of Consumer Complaining Behavior, in Consumer and Industrial Buying Behavior, A. Woodside, J. Sheth \& P. Bennett, eds. Amsterdam: North-Holland Publishing Company. Og dels af Singh, J. (1988), Consumer Complaint Intentions and Behavior: Definitional and Taxonomical Issues, Journal of Marketing, Vol. 52, pp. 93-107.
} 
Virksomhedens omdømme kan lide skade, såfremt kunden vælger at fortælle om sin utilfredshed til tredjepart (venner, bekendte, medier mv.). Undersøgelser tyder på, at en utilfreds kunde i gennemsnit fortæller om sin utilfredshed til op mod 10-11 andre personer. (3) Virksomheden opnår ikke mulig værdifuld feedback omkring eventuelle forbedringer af sine varer, sin kommunikation, øvrig service mv. En række forhold synes at være betydende for en kundes klagetilbøjelighed ${ }^{2}$ :

- Magtforhold: Mange kunder undlader at klage på grund af, at de oplever en magtesløshed, når magtforholdet imellem kunde og virksomhed er uligeværdigt. Sådanne kunder vil måske tænke, at det ikke kan betale sig at klage og/eller de kan frygte, at deres synspunkter negligeres eller, at de måske ligefrem ydmyges af virksomhedens naturligt større indsigt i den pågældende vare og eventuelt tilknyttede ydelser.

- Klageadgang: Kunder vil kunne undlade at klage, hvis de er i tvivl om, hvor klagen skal afleveres, og om modtageren i det hele taget er interesseret $i$ at fă tilkendegivelser om kundens utilfredshed. Kunderne bør bibringes den opfattelse, at deres synspunkter og kommentarer i forhold til virksomhedens varer og tilknyttede ydelser er væsentlige for virksomheden, og at kunden derfor vil blive taget alvorligt. Kunder som oplever begrænsninger i fysisk (f.eks. manglende information om klagemuligheder, manglende kontaktmuligheder) og/eller psykologisk (forbrugerens opfattelse af virksomhedens syn på klager) klageadgang vil naturligt være mindre tilbøjelige til at klage.

- Kundens kompetencer: Kunder, som ikke besidder de nødvendige kompetencer til at kunne gennemskue varens kvaliteter og/eller den ledsagende information og eventuelle tilknyttede ydelser vil sandsynligt være tilbageholdende med at klage. Dels fordi de vil kunne være usikre på, om der overhovedet er 'noget at klage over', og dels fordi de vil kunne være bange for at 'falde igennem' i forhold til virksomheden, jf. vedrørende 'magtforhold' ovenfor. Kunders kompetencer vil typisk være svagere i forbindelse med f.eks. højteknologiske produkter, komplicerede service ydelser (f.eks. advokatbistand) mv.

- Dårlige klageerfaringer: Kunder, som tidligere har klaget til virksomheden, vil formentlig være tilbageholdende med fremtidige klage, hvis de tidligere har oplevet, at virksomheden ikke har taget dem alvorligt, at de har fået manglende kompensation og/eller, at virksomheden ikke har fulgt op på klagen (har løst problemet).

\footnotetext{
${ }^{2}$ Det følgende bygger delvist på Stephens, N. \& K.P. Gwinner (1998), Why Don’t Some people Complain? A Cognitive-Emotive Process Model of Consumer Complaint Behavior, Journal of the Academy of Marketing Science, Vol. 26, No. 3, pp. 172-189.
} 
Desuden vil kunden kunne generalisere fra én dårlig oplevelse hos én virksomhed til andre virksomheder.

- Forventet klageresultat: Utilfredshed kan i sig selv ses som en motivation til at overveje at klage. Men som antydet af flere tidligere forfattere ${ }^{3}$ vil kunden vurdere det forventede udbytte af klagen set $\mathrm{i}$ forhold til det forventelige ressourceforbrug (tid, penge og/eller mentale ressourcer).

- Personspecifikke faktorer: Foretagne undersøgelser peger på, at jo mere aggressiv ${ }^{4}$, selvsikker ${ }^{5}$ og/eller selvbevidst ${ }^{6}$ en kunde er, jo mere tilbøjelig synes denne at være til at klage. Tilsvarende synes kunder som generelt finder det $\mathrm{i}$ orden at klage ${ }^{7}$ og kunder, som har en positiv indstilling 'toward business in general ${ }^{18}$ at være mere tilbøjelige til at klage sammenlignet med kunder, som ikke besidder disse karakteristika. Desuden synes kundens klagetilbøjelighed at være højere for yngre end for ældre kunder samt desuden at være stigende jo højere indkomst kunden har og jo bedre uddannet denne er?

\subsubsection{Klagebehandlingen}

Virksomhedens klagebehandling har stor betydning for relationen imellem kunde og virksomhed. F.eks. peger en undersøgelse på, at over $80 \%$ af klagende kunder vil foretage genkøb, såfremt kunderne oplever, at deres klager tages alvorligt samt behandles fair og effektivt ${ }^{10}$. Om kunderne oplever en fair klagebehandling vil kunne bero på såvel kundernes oplevelse af interaktionen imellem kunde og virksomhed, den eventuelt opnåede kompensation som virksomhedens villighed til at foretage klagebaseret tilpasning. Kunderne vil med andre ord se på både selve klageprocessen og på klageprocessens resultat. ${ }^{11}$

Når klagen er modtaget og behandlet, skal kunden orienteres om udfaldet, med hensyn til kompensation og/eller tilpasning. Det kan være, at

\footnotetext{
${ }^{3}$ F.eks. Stephens, N. \& K.P. Gwinner (1998, op. cit.) samt Day, R.L. (1984), Modelling Choices Among Alternative Responses to Satisfaction, Advances in Consumer Research, Vol. 11, Eds. T.C. Kinnear, Provo, UT, ACR, pp. 438-444.

${ }^{4}$ Richins, M.L. (1983), An Analysis of Consumer Interaction Styles in the Marketplace, Journal of Consumer Research, 10 (June), pp. 68-78.

${ }_{6}^{5}$ Richins, M.L. (1983, op. cit.).

${ }^{6}$ Gronhaug, K. \& G. Zaltman (1981), Complainers and Non-complainers Revisited: Another Look at the Data Advances in Consumer Research, K. Monroe (ed.), 8, pp. 83-87.

${ }^{7}$ Richins, M.L. (1981), An Investigation of Consumers Attitudes Toward Complaining, Advances in Consumer Research, K. Monroe (Ed.), 8, pp. 502-506.

${ }^{8}$ Jacoby, J. \& Jaccard, J.J. (1981), The Sources, Meaning, and Validity of Consumer Complaint Behavior: A Psychological Analysis, Journal of Retailing, 57(3), pp. 4-24.

${ }^{9}$ Singh, J. (1990), A Typology of Consumer Dissatisfaction Response Styles, Journal of Retailing, 66(1), pp. 57-99,

${ }^{10}$ (a) Whiteley, R.C. (1991), The Customer Driven Company: Moving From Talk to Action, Reading, MA: Addison-Wesley. (b) Walker, D. (1990), Customer First: A Strategy for Quality Service, Aldershot, England: Gower.

${ }^{11}$ Singh, J. (1990), Voice, Exit, and Negative Word-of-Mouth Behaviors: An Investigation Across Three Service Categories, Journal of the Academy of Marketing Science, 18 (Winter), pp. 115.
} 
man får udskiftet en defekt vare, at man får penge tilbage for sin defekte vare, eller at man får et stykke chokolade for sin ulejlighed. Det kan også være, at virksomheden ændrer på fysiske placeringer, eller at den ændrer et varesortiment på baggrund af klagen. Og endelig kan det også være, at forretningen ikke kan afhjælpe kunden med dennes ønsker. Uanset hvilken tilbagemelding kunden skal have, så er det væsentligt at forklare kunden, hvorfor udfaldet er blevet som det er og frem for alt at gøre kunden opmærksom på, hvorfor man er taknemlig for dennes klage.

Procedural justice (fairness): En stor del af litteraturen ${ }^{12}$ vedrørende kundens kompensation, og evt. efterfølgende tilpasning, tager udgangspunkt i begrebet 'procedural justice', som bedst kan oversættes som 'kundens oplevelse af at få en fair behandling'. Mere formelt kan begrebet beskrives som 'the perceived fairness of a process that culminates in an event, decision, or action ${ }^{13}$. Flere undersøgelser ${ }^{14}$ viser i denne forbindelse, at kunder gennemgående har en stor retfærdighedssans og desuden er meget optagede af at opnå en fair behandling. Ligeledes peger undersøgelser på, at kunder ofte adskiller selve klagebehandlingsprocessen fra resultatet (kompensation, klagebaseret tilpasning) af klagebehandlingsprocessen ${ }^{15}$. En række sammenligninger ${ }^{16}$ af kundernes opfattede relevans og vigtighed af klagebehandlingsprocessen med kundernes opfattede relevans og vigtighed af klagebehandlingens resultater viser, at kunder gennemgående er mere optagede af at opnå en fair behandling under selve interaktionen (ikke mindst hvor denne indebærer personlig kontakt) end af at opnå et bestemt resultat af klageprocessen. Dette betyder, at et set fra kundens synspunkt, positivt klageresultat næppe vil være i stand til at kompensere for en mindre god kunde-virksomhed interaktion, dvs. kunden vil sandsynligvis - samlet set - få en negativ oplevelse.

I almindelighed antages 'procedural justice' at omfatte i alt fire underliggende dimensioner:

- Bilateral kommunikation

- Indlevelse/indføling i klagerens situation

- Klagerens indflydelse på klagebehandlingsprocessen og på dens resultat

- Klagebehandlingens konsistens

\footnotetext{
${ }^{12}$ Se f.eks. Saxby, C.L., Tat, P.K. \& Johansen, J.T. (2000), Measuring Consumer Perceptions of Procedural Justice in a Complaint Context, Journal of Consumer Affairs, Vol. 34, No. 2, pp. 204-216.

${ }^{13}$ Sheppard, B.H., Lewicki, R.J. \& Minto, J.W. (1992), Organizational Justice, New York: Lexington Books.

${ }^{14}$ Se f.eks. Lind, E.A. \& Tyler, T.R. (1988), The Social Psychology of Procedural Practice, New York: Plenum Press.

${ }^{15}$ Singh, J. \& Widing, R.E. (1990), What Occurs Once Consumers Complain? A Theoretical Model for Understanding Satisfaction/Dissatisfaction Outcomes of Complaint Responses, European Journal of Marketing, 25 (5), pp. 30-46.

${ }^{16}$ Se f.eks. Lind, E.A. \& Tyler, T.R. (1988), op.cit.; Greenberg, J. (1990), Organizational Justice: Yesterday, Today, and Tomorrow, Journal of Management, 16 (2), pp. 399-432.
} 
Bilateral kommunikation: Den bilaterale kommunikationen vedrører kundens egen oplevelse af, i hvilket omfang kunden er i stand til og får mulighed for at indgå i en to-vejs (bilateral) kommunikation med virksomheden. Kundens vurderingen af den bilaterale kommunikation vil kunne påvirkes af kundens mulighed for at stille og få besvaret spørgsmål, kundens indflydelse på beslutningsprocessen, kundens og virksomhedens kompetencer mv. Bl.a. Greenberg (1990) $)^{17}$ og Gilliand (1993) ${ }^{18}$ har vist, at kundens oplevelse af den bilaterale kommunikation vil kunne have indflydelse på kundens oplevelse af, om denne får en fair behandling.

Indlevelse i klagerens situation: Virksomhedens indlevelse i kundens situation omfatter såvel den mere videns- og kompetencebaserede forståelse for kundens klagekriterier såvel som indføling med kundens følelsesprægede og måske endda stressede situation. En kunde, som ikke mødes af sådanne forhold hos virksomheden, vil kunne have vanskeligt ved at gennemskue virksomhedens behandling af vedkommende og vil ikke opleve at blive 'taget alvorligt'. Begge forhold vil kunne nedsætte kundens oplevelse af klagebehandlingens fairness.

Klagerens indflydelse på klagebehandlingsprocessen og på dens resultat: Denne dimension vedrører kundens mulighed for at kunne påvirke og/eller imødegå beslutninger truffet af virksomheden samt kundens påvirkningsmuligheder under selve klagebehandlingsprocessen. Kunder, som gives disse muligheder, vil være tilbøjelige til at opfatte virksomhedens som åben og lyttende og som værende villig til at give kunden en fair behandling.

Klagebehandlingens konsistens: Konsistens henviser til kundens oplevelse af, om klagebehandlingens og dens resultat er konsistent $\mathrm{i}$ forhold til forskellige kunder og i forhold til tid. I modsat fald vil klagebehandlingen og dens resultat fremstå tilfældig - modsat systematisk - for kunden. Dette betyder samtidig, at kunden vil kunne opleve en forøget usikkerhed i forbindelse med klagebehandlingen, idet kunden jo nu ikke kan være sikker på, hvad andre kunder kunne have fået/opnået, eller hvad kunden kunne have opnået, hvis denne var kommet på et 'bedre tidspunkt'. En sådan kunde vil næsten ligegyldigt, hvad klagebehandlingens indhold og resultat så end måtte bestå i, næppe blive tilfreds samlet set.

\subsubsection{Klagebehandlingens hovedområder}

Grundlæggende omfatter klagebehandling følgende hovedområder:

1. Klageopfordring/invitation

2. Kunde-virksomhedsinteraktion

3. Klageresultat/-kompensation

4. Evt. klagebaseret tilpasning

\footnotetext{
${ }^{17}$ Greenberg, J. (1990), op. cit.

${ }^{18}$ Gilliand, S. W. (1993), The Perceived Fairness of Selection Systems: An Organizational Perspective, Academy of Management Review, 18 (4), pp. 694-734.
} 
Klageopfordring handler om de tiltag, som virksomheden anvender med henblik på at få eventuelle utilfredse kunder til at henvende sig til virksomheden frem for til tredjepart.

Interaktion handler om det samspil og den gensidige kommunikation, der foregår i forbindelse med utilfredshed og klager. Vi opererer efterfølgende med den interaktion, der foregår før, under og efter klageafgivelse.

Klageresultat/-kompensation handler dels om, hvordan man kompenserer for at have gjort kunden utilfreds, og dels om hvordan man kompenserer eller belønner kunden for at have givet udtryk for sin utilfredshed via klageafgivelse. Desuden omfatter dette hovedområde resultatet af klagebehandlingen (afvises kunden, gives kunden betinget eller ubetinget medhold mv.).

Klagebaseret tilpasning handler om, i hvilket omfang virksomheden tilpasser sig de klagende kunders ønsker og behov - og herunder specifikt de forhold der kan forebygge utilfredshed fremover. Vi taler om at tilpasse sig og indrette sig på baggrund af klager.

\subsection{Rapportens videre struktur}

Kapitlerne 4-7 omhandler en afrapportering af undersøgelsens resultater i tilknytning til klagebehandlingens hovedområder. Desuden ses der i disse kapitler på virksomhedernes syn klagehåndteringsprocedurer, intern klagekulturer i virksomhederne samt (i kapitel 7) virksomhedernes forhold til lovgivning, ankenævn mv. Et sammendrag af undersøgelsen findes i kapitel 8, mens der i kapitel 9 gives et English Summary. I det følgende kapitel 3 redegøres for undersøgelsens metode, validitet og reliabilitet. 


\section{Metode}

Denne rapports resultater er baserede på en spørgeskemaundersøgelse af i alt 128 danske virksomheder og 132 svenske virksomheder. I begge lande er virksomhederne fordelt på fire brancher: møbelforhandlere, dagligvareforhandlere, elektronikforhandlere og bilforhandlere (tabel 3.1):

Tabel 3.1 Antal virksomheder i undersøgelsen

- fordelt på lande og brancher

\begin{tabular}{lrr}
\hline & Danmark & Sverige \\
\hline Møbelforhandlere & 34 & 30 \\
Dagligvareforhandlere & 31 & 35 \\
Elektronikforhandlere & 33 & 36 \\
Bilforhandlere & 30 & 31 \\
I alt & 128 & 132 \\
\hline
\end{tabular}

I det følgende beskrives, hvorledes de deltagende virksomheder (undersøgelsens sample) er udvalgt og kontaktet, undersøgelsens svarprocenter og de deltagende virksomheders karakteristika.

\subsection{Udvælgelse af de undersøgte virksomheder}

Identificering, udvælgelse og kontakt til undersøgelsens virksomheder blev foretaget af Catinét Research (Danmark) i samråd med udrederne af denne rapport.

Danmark: Med henblik på i første omgang at identificere virksomheder tilhørende de enkelte brancher blev databasen NEWBIZ benyttet. NEWBIZ er en del af Bonnier Business Information, som er specialiseret $i$ at indsamle erhvervsinformation. NEWBIZ-databasen opdateres fire gange årligt. Der blev identificeret i alt 6.857 virksomheder fordelt på de fire brancher, hvor 2.879 virksomheder på forhånd blev frasorteret som følge af mangelfuld eller slet ingen informationer om disse (f.eks. i tilfælde hvor antallet af ansatte blev opgivet til 0 , eller hvor der slet ingen informationer var om antallet af ansatte).

Sverige: I Sverige blev 5.490 virksomheder identificeret ved hjælp af MM Partner, som er en svensk partner til NEWBIZ. I Sverige blev der ikke frasorteret virksomheder.

Fordelingen af de i alt 3.978 (6.857-2.879) danske og de i alt 5.490 svenske udvalgte virksomheder på de fire brancher er angivet $i$ tabel 3.2. 
Tabel 3.2 Antal virksomheder som blev udvalgt til potentielt at kunne indgå i undersøgelsen - fordelt på lande og brancher

\begin{tabular}{lrr}
\hline & Danmark & Sverige \\
\hline Møbelforhandlere & 733 & 857 \\
Dagligvareforhandlere & 1034 & 2642 \\
Elektronikforhandlere & 741 & 1055 \\
Bilforhandlere & 1480 & 935 \\
l alt & 3978 & 5490 \\
\hline
\end{tabular}

Virksomhederne i de udvalgte samples blev for både Danmark og Sverige randomiseret og derefter lagt ind i Catinéts CATI-system (Computer Assisted Telephone Interviewing). Virksomhederne blev ved hjælp af CATI systemet kontaktet via telefon. Af de i alt 3.978 og 5.490 udvalgte danske og svenske virksomheder indvilgede henholdsvis 297 (svarende til 7.5\% af det udvalgte sample) og 532 (svarende til 9.7\% af det udvalgte sample) virksomheder $\mathrm{i}$ at deltage $\mathrm{i}$ undersøgelsen.

Ved tilsagn om deltagelse fremsendte virksomhederne deres email adresse, hvorefter de fik fremsendt en mail med et link til selv spørgeskemaet, som var placeret på Catinés Internetbaserede survey-system CatGlobe. Respondenterne loggede sig således på Catinés server og udfyldte spørgeskemaerne dér. Respondenten blev udvalgt som 'en person i virksomheden, som har indflydelse på og indsigt $\mathrm{i}$ udformningen og anvendelsen af virksomhedens klagehåndtering'.

\subsubsection{Deltagende virksomheder i undersøgelsen}

Danmark: Af de 297 danske virksomheder/respondenter, som indvilgede $i$ at deltage i undersøgelsen, besvarede 138 hele spørgeskemaet. Af disse 138 blev 10 efterfølgende bortsorteret på grund af en ukorrekt udfyldelse af spørgeskemaet, således at undersøgelsens endelige sample er 128 (DK) virksomheder. Herudover udfyldte 56 danske virksomheder/respondenter kun delvist spørgeskemaet. Disse kunne derfor ikke medtages i undersøgelsen.

Sverige: 142 af de 532 svenske virksomheder/respondenter, som havde indvilget $i$ at deltage $i$ undersøgelsen, besvarede hele spørgeskemaet. 10 virksomheder/respondenter blev efterfølgende bortsorteret som følge af en ukorrekt udfyldelse af spørgeskemaet. Undersøgelsen endelige sample er således på 132 (S) virksomheder. Desuden udfyldte 72 danske virksomheder/respondenter kun delvist spørgeskemaet. Disse kunne derfor ikke medtages i undersøgelsen.

I tabel 3.3 er anført de deltagende virksomheders karakteristika. 
Tabel 3.3. Virksomhedernes karakteristika

\begin{tabular}{|c|c|c|c|c|c|c|c|c|c|c|}
\hline \multirow{3}{*}{$\begin{array}{l}\text { Land } \\
\text { Branche }\end{array}$} & \multicolumn{5}{|c|}{ Danmark } & \multicolumn{5}{|c|}{ Sverige } \\
\hline & Møbler & $\begin{array}{c}\text { Daglig- } \\
\text { varer }\end{array}$ & $\begin{array}{l}\text { Elek- } \\
\text { tronik }\end{array}$ & Biler & $\begin{array}{r}\begin{array}{r}\text { Statis- } \\
\text { tiske } \\
\text { forskelle }\end{array}\end{array}$ & Møbler & $\begin{array}{l}\text { Daglig- } \\
\text { varer }\end{array}$ & $\begin{array}{l}\text { Elek- } \\
\text { tronik }\end{array}$ & Biler & $\begin{array}{r}\text { Statis- } \\
\text { tiske } \\
\text { forskelle* }\end{array}$ \\
\hline & A & B & C & D & & A & B & C & D & \\
\hline a. Antal ansatte & 12.4 & 15.7 & 10.9 & $44.6^{a}$ & $A, B, C<D$ & 10.3 & 29.8 & $22.7^{b}$ & $44.6^{b}$ & $A<B, D$ \\
\hline $\begin{array}{l}\text { b. Antal år virks. (eller } \\
\text { virksomhedsafdelin- } \\
\text { gen) har eksisteret }\end{array}$ & 32.2 & 55.6 & 19.9 & 29.2 & $B>C, D$ & 38.0 & 25.9 & 23.0 & 34.5 & $A>B, C$ \\
\hline $\begin{array}{l}\text { c. Virks. overskud i } \\
\text { seneste regnskabsår } \\
\text { (\% af omsætning) }\end{array}$ & $11.9 \%$ & $5.6 \%$ & $14.9 \%$ & $3.8 \%$ & $\begin{array}{r}B, D<C ; \\
A>D\end{array}$ & $6.6 \%$ & $4.6 \%$ & $11.2 \%$ & $3.5 \%$ & $B, D<C$ \\
\hline $\begin{array}{l}\text { d. Virks. omsætning i } \\
\text { seneste regnskabsår } \\
\text { (mill. kr.) }\end{array}$ & 19.6 & 20.8 & 9.8 & 101.3 & $A, B, C<D$ & 25.3 & 72.0 & 22.2 & 127.4 & $A, C<D$ \\
\hline
\end{tabular}

Note: Tallene i tabellen er gennemsnitstal.

a : Tallet dækker over, at en bilforhandler har 450 ansatte. Tages denne forhandler bort er gennemsnittet 30.7 ansatte hos

bilforhandlerne. Dette berører dog ikke de angivne statistiske forskelle.

b: Tallene dækker over, at en elektronikforhandler har 550 ansatte, og at en bilforhandler har 400 ansatte. Dette berører dog ikke de angivne statistiske forskelle.

\subsection{Undersøgelsens reliabilitet og validitet}

Reliabilitet og validitet vedrører undersøgelser af, i hvilket omfang de data som indsamles er behæftet med henholdsvis tilfældige og systematiske fejl. Da en måling af et teorikoncept (f.eks. opfattet kundetilfredshed) alene kan være udtryk for en tilnærmet værdi af teorikonceptet, og ikke konceptets 'sande værdi', vil den målte værdi kunne afvige fra den sande værdi. Sammenhængene imellem den sande og den målte værdi samt fejlkilderne kan vises som:

$\mathrm{Xo}=\mathrm{Xt}+\mathrm{Xs}+\mathrm{Xr}$

hvor:

$$
\begin{array}{ll}
\mathrm{Xo}= & \text { Den målte værdi } \\
\mathrm{Xt}= & \text { Den sande værdi } \\
\mathrm{Xs}= & \text { Systematiske fejl } \\
\mathrm{Xr}= & \text { Tilfældige fejl }
\end{array}
$$

Såfremt $\mathrm{Xs}=\mathrm{Xr}=0$ er dette udtryk for, at en undersøgelse har en perfekt validitet $(\mathrm{Xs}=0)$ og reliabilitet $(\mathrm{Xr}=0)$. Da dette dog sjældent vil være tilfældet i den samfundsvidenskabelige forskning accepteres normalt en vis grad af tilfældige og systematiske fejl. Reliabilitet og validitet bør ikke betragtes som uafhængige fejlkilder. Således er reliabilitet en nødvendig, men ikke tilstrækkelig, betingelse for validitet. 
Raliabilitet: Tilfældige fejl kan opstå af en lang række årsager og nogen udtømmende liste over mulige fejlkilder kan vanskeligt opstilles. I det følgende beskrives, hvad der i undersøgelsen er gjort med henblik på at minimere tilstedeværelsen af tilfældige fejl:

Såfremt de spørgsmål der indgår i undersøgelsen er flertydige, vil respondenterne kunne opfatte disse forskelligt og tilfældigt. Med henblik på at undgå dette blev operationaliseringerne af de teoretiske koncepter gennemført i flere trin, hvor hvert enkelt trin indeholdt særskilte vurderinger af operationaliseringerne:

- Med udgangspunkt i tidligere teoretiske og empiriske undersøgelser blev indledningsvist udarbejdet et første udkast til spørgsmålenes operationalisering.

- Udkastet blev herefter vurderet af 5 eksperter i afsætningsøkonomi (kolleger), som alle var bekendte med undersøgelsens design og formål, samt af 3 ikke-eksperter (venner og familie). Fomålet hermed var at undgå flertydigheder og uklarheder i spørgsmålene og dermed at opnå et første indtryk af operationaliseringernes reliabilitet og validitet. Dette trin gav anledning til, at der blev foretaget en række justeringer af operationaliseringerne. Efter disse justeringer blev spørgsmålene eksponeret for yderligere 2 ikke-eksperter.

Gennemførelsen af dette trin gav alene anledning til en række mindre korrektioner.

- Endelig blev gennemført et (mindre) pretest, $\mathrm{n}=4$. Pre-testene gav ikke anledning til at foretage yderligere justeringer af de anvendte operationaliseringer.

Herudover blev undersøgelsen gennemført konsistent og ved anvendelse af samme procedure for samtlige respondenter for at minimere omfanget af tilfældig støj i undersøgelsen. I løbet af afrapporteringen (afsnit 4-7) gives udover de ovennævnte kvalitative vurderinger af undersøgelsens reliabilitet desuden kvantitative vurderinger af reliabiliteten. Disse sidste undersøgelser giver ikke anledning til at betvivle undersøgelsens reliabilitet.

Validitet: I undersøgelsen må der nødvendigvis være korrespondance imellem de operationelle definitioner og de teoretiske koncepter. I modsat fald vil teoritestningen kunne lide af mangel på definitionsvaliditet. Definitionsvaliditet (skalavaliditet) angiver i hvilket omfang en operationalisering faktisk måler det teorikoncept, som den er designet til at måle. De gennemførte konfirmative faktoranalyser (jf. afsnit 4-7) giver ikke anledning til at betvivle undersøgelsens definitionsvaliditet.

Undersøgelsens eksterne validitet vedrører i hvilket omfang undersøgelsens resultater kan generaliseres til hændelser uden for undersøgelsen, dvs. spørgsmålet om reprcesentativitet. I denne forbindelse kan den nødvendige stikprøve (for opnåelse af et $95 \%$ konfidensniveau og en 
fejlmargin på $5 \%)^{19}$ beregnes til mindst 250 tilfældigt udvalgte virksomheder pr. branche. De resultater, som præsenteres i denne rapport kan derfor ikke antages at være repræsentative for populationen af virksomheder i de to lande/fire brancher. De præsenterede resultater må i stedet anses som indikatorer for de faktiske forhold i de undersøgte populationer.

${ }^{19}$ En fejlmargin på 5\% betyder, at såfremt f.eks. $40 \%$ af stikprøven vælger en given svarmulighed, så kan man antage, at $40 \%( \pm 5 \%)$ af populationens virksomheder ville vælge den samme mulighed, hvis de blev spurgt. Konfidensniveauet angiver med hvilken sikkerhed man kan antage denne sammenhæng imellem stikprøvens og populationens virksomheder. Et 95\% konfidensniveau betyder, at man med 5\% usikkerhed ikke kan afvise, at antagelsen holder stik. En fejlmargin på 5\% og et 95\% konfidensniveau er det almindelige valg i forskningslitteraturen. Undersøgelsens resultater har med den opnåede stikprøve en fejlmargin på ca. $16.5 \%$. Denne fejlmargin kan angives med $95 \%$ sikkerhed. 



\section{Opfattelse af klagebehandling og kundeklager}

Klagebehandling kan af virksomheden naturligvis opfattes som et 'nødvendigt onde', som blot skal udføres i tilfælde af, at nogle kunder skulle vælge at klage. Men klagebehandling kan også betragtes mere aktivt som et strategisk værktøj, dvs. et værktøj som grundlæggende kan forbedre virksomhedens stilling på markedet.

I den øverste del af tabel 4.1 er vist svarene på tre spørgsmål, som tilsammen giver et billede af virksomhedernes grundlæggende syn på klagebehandling. Svarende er for hvert land fordelt på de fire brancher, ligesom de eventuelle statistiske forskelle (max. 5\% statistisk usikkerhed) imellem de gennemsnitlige svar for de enkelte brancher er beregnede.

Svarende for spørgsmål a og c er gennemgående under midten (=værdien 3) på den anvendte 5-punkt skala, mens svarende for spørgsmål b ligger omkring midten. Det er ikke udbredt blandt de undersøgte virksomheder at betragte klagebehandling som et strategisk værktøj (spm. a), selvom der dog er forskelle både med hensyn til branche og land. I Danmark er navnlig dagligvareforhandlere utilbøjelige til at betragte klagebehandling som et strategisk værktøj, mens det i Sverige især er møbelog elektronikforhandlere, som er tilbageholdende. Med en gennemsnitlig værdi på lidt over midten på den anvendte skala er de svenske bilforhandlere de klart mest positive over for tanken om, at klagebehandling bør betragtes som et strategisk værktøj.

Dette sidste resultat støttes til dels af svarende på spørgsmål b og c. Svenske bilforhandlere er mest tilbøjelige til at basere virksomhedens klagebehandling på skriftligt formulerede politikker, som specificerer procedurer mv. for virksomhedens klagebehandling (spm. c). Også i Danmark opnår bilforhandlerne på dette spørgsmål det højeste gennemsnit blandt de fire brancher, omend resultatet her skal ses i lyset af, at gennemsnittene for de øvrige tre brancher er meget lave. Selvom virksomhederne gennemgående kun i meget begrænset omfang (gennemsnit betydeligt under skalamidten) opfatter klagebehandling som et strategisk værktøj, forhindrer dette ikke, at topledelsen i et vist omfang engagerer sig i virksomhedens daglige klagebehandling (spm. b). Det største omfang af topledelsens engagement findes hos de danske og svenske bilforhandlere. Ud fra en betragtning om, at topledelsens primære ansvar er at stå for den strategiske ledelse af virksomheden, er det lidt overraskende, at topledelsen engagerer sig ganske pænt $\mathrm{i}$ den daglige klagebehandling samtidig med, at klagebehandling kun i begrænset omfang opfattes som et strategisk værktøj. 
Tabel 4.1 Virksomhedernes syn på klagebehandling og kundeklager

\begin{tabular}{|c|c|c|c|c|c|c|c|c|c|c|}
\hline \multirow{3}{*}{$\begin{array}{l}\text { Land } \\
\text { Branche }\end{array}$} & \multicolumn{5}{|c|}{ Danmark } & \multicolumn{5}{|c|}{ Sverige } \\
\hline & Møbler & $\begin{array}{l}\text { Daglig- } \\
\text { varer }\end{array}$ & $\begin{array}{l}\text { Elek- } \\
\text { tronik }\end{array}$ & Biler & $\begin{array}{r}\text { Statis- } \\
\text { tiske } \\
\text { for- } \\
\text { skelle* }\end{array}$ & Møbler & $\begin{array}{l}\text { Daglig- } \\
\text { varer }\end{array}$ & $\begin{array}{l}\text { Elek- } \\
\text { tronik }\end{array}$ & Biler & $\begin{array}{r}\text { Statis- } \\
\text { tiske } \\
\text { for- } \\
\text { skelle* }^{*}\end{array}$ \\
\hline & A & B & C & D & & A & B & C & D & \\
\hline \multicolumn{11}{|l|}{$\begin{array}{l}\text { Angiv, i hvilket omfang flg. } \\
\text { aspekter indgår i virks. } \\
\text { klagehåndteringa: }\end{array}$} \\
\hline $\begin{array}{l}\text { a. Klagebehandling opfattes } \\
\text { som et strategisk værktøj }\end{array}$ & 2.06 & 1.26 & 1.94 & 2.10 & $\begin{array}{r}B<A, C, \\
D\end{array}$ & 2.27 & 2.46 & 2.22 & 3.16 & $A, C<D$ \\
\hline $\begin{array}{l}\text { b. Topledelsen engagerer } \\
\text { sig mere eller mindre i virks. } \\
\text { daglige klagebehandling }\end{array}$ & 3.15 & 3.00 & 2.76 & 3.90 & $B, C<D$ & 2.70 & 3.34 & 2.92 & 3.52 & $A<D$ \\
\hline $\begin{array}{l}\text { c. Virks. klagebehandling er } \\
\text { baseret på skriftligt formule- } \\
\text { rede politikker, som specifi- } \\
\text { cerer procedurer mv. for } \\
\text { virks. Klagebehandling }\end{array}$ & 1.50 & 1.03 & 1.24 & 1.83 & $B, C<D$ & 1.87 & 1.57 & 1.86 & 2.58 & $\begin{array}{r}A, B, C< \\
D\end{array}$ \\
\hline $\begin{array}{l}\text { I hvilket omfang er følgende } \\
\text { holdninger udbredte i jeres } \\
\text { virks.? }{ }^{b}\end{array}$ & -- & -- & $=-$ & & $=-$ & --- & --- & -- & -- & --- \\
\hline $\begin{array}{l}\text { a. Klagende kunder er } \\
\text { besværlige kunder }\end{array}$ & 1.97 & 1.87 & 1.70 & 1.97 & Ingen & 2.00 & 1.60 & 1.94 & 1.94 & Ingen \\
\hline $\begin{array}{l}\text { b. Klagende kunder er en } \\
\text { økonomisk omkostning }\end{array}$ & 2.12 & 1.65 & 1.97 & 2.43 & $B<D$ & 2.37 & 1.46 & 2.14 & 2.42 & $\begin{array}{r}A, C, D \\
>B\end{array}$ \\
\hline $\begin{array}{l}\text { c. Klagende kunder besidder } \\
\text { vigtig information }\end{array}$ & 2.94 & 2.65 & 3.30 & 3.10 & Ingen & 3.17 & 3.09 & 3.00 & 3.90 & $\begin{array}{r}A, B, C \\
<D\end{array}$ \\
\hline $\begin{array}{l}\text { d. Klagende kunder er } \\
ø \text { delæggende for arbejds- } \\
\text { klimaet }\end{array}$ & 1,82 & 1.55 & 1.76 & 1.60 & Ingen & 1.87 & 1.54 & 1.81 & 1.87 & Ingen \\
\hline $\begin{array}{l}\text { e. Klagende kunder er } \\
\text { psykisk belastende } \\
\text { Hvilken betydning har det: c: }\end{array}$ & 2.18 & 1.97. & 2.27 & 1.87 & Ingen & 1.87 & 1.57 & 1.97 & 1.87 & Ingen \\
\hline $\begin{array}{l}\text { a. At virks. investering i } \\
\text { klagebehandling/complaint } \\
\text { management kan forrente } \\
\text { sig? }\end{array}$ & 2.32 & 2.58 & 2.45 & 3.27 & $\begin{array}{r}A, B, C< \\
D\end{array}$ & 2.72 & 2.57 & 2.78 & 3.55 & $\begin{array}{r}A, B, C \\
<D\end{array}$ \\
\hline
\end{tabular}

Noter:

${ }^{a}, \mathrm{~b}: 5$-punkt-skala, hvor $1=\mathrm{i}$ meget lille omfang og $5=\mathrm{i}$ meget stort omfang.

c: 5 -punkt-skala, hvor $1=$ =meget lille betydning og $5=$ =meget stor betydning.

Tallene i tabellen repræsenterer gennemsnit på den anvendte skala.

* Signifikansniveau: $5 \%$

I den midterste del af tabel 4.1 er angivet virksomhedernes svar på i hvilket omfang en række holdninger til klagende kunder er udbredte i virksomhederne. I gennemsnit mener samtlige brancher, i begge lande, kun i begrænset omfang, at klagende kunder er besværlige kunder (spm. a), at klagende kunder er en økonomiske omkostning (spm. b), at klagende kunder er ødelæggende for arbejdsmiljøet (spm. d) og at klagende kunder er psykisk belastende (spm. e). I Danmark er bilforhandlere mere tilbøjelige end dagligvareforhandlere til at se klagende kunder som en økonomisk omkostning. Også i Sverige er dagligforhandlere mindst tilbøjelige til at opfatte klagende kunder som en økonomisk omkostning - og her mindre tilbøjelige end både møbel, elektronik- og bilforhandlerne. 
Tabel 4.2 Opfattet kundetilfredshed og klageadfærd

\begin{tabular}{|c|c|c|c|c|c|c|c|c|c|c|}
\hline \multirow{3}{*}{$\begin{array}{l}\text { Land } \\
\text { Branche }\end{array}$} & \multicolumn{5}{|c|}{ Danmark } & \multicolumn{5}{|c|}{ Sverige } \\
\hline & Møbler & $\begin{array}{l}\text { Dag- } \\
\text { lig- } \\
\text { varer }\end{array}$ & $\begin{array}{l}\text { Elek- } \\
\text { tronik }\end{array}$ & Biler & $\begin{array}{r}\text { Statis- } \\
\text { tiske } \\
\text { for- } \\
\text { skelle* }\end{array}$ & Møbler & $\begin{array}{l}\text { Dag } \\
\text { lig- } \\
\text { va- } \\
\text { rer }\end{array}$ & $\begin{array}{l}\text { Elek- } \\
\text { tronik }\end{array}$ & Biler & $\begin{array}{r}\text { Statis- } \\
\text { tiske } \\
\text { for- } \\
\text { skelle* }^{*}\end{array}$ \\
\hline & A & B & C & D & & A & B & c & D & \\
\hline \multicolumn{11}{|l|}{$\begin{array}{l}\text { Andel af kunder som } \\
\text { ifølge virksomhedens } \\
\text { vurdering: }\end{array}$} \\
\hline $\begin{array}{l}\text { a. Har været utilfredse } \\
\text { med virks. produk- } \\
\text { ter/ydelser }\end{array}$ & 2.00 & 1.52 & 1.48 & 2.00 & Ingen & 2.03 & 2.03 & 1.75 & 2.10 & Ingen \\
\hline $\begin{array}{l}\text { b. Har været utilfredse } \\
\text { med virks. informati- } \\
\text { onsafgivning og/el. } \\
\text { rådgivning }\end{array}$ & 1.85 & 1.16 & 1.24 & 1.47 & $A>B, C$ & 2.00 & 1.77 & 1.86 & 1.81 & Ingen \\
\hline $\begin{array}{l}\text { c. Har været utilfredse } \\
\text { med virks. af anden } \\
\text { årsag }\end{array}$ & 1.65 & 1.39 & 1.21 & 1.50 & $A>C$ & 1.60 & 1.94 & 1.56 & 1.55 & Ingen \\
\hline d. Har klaget til virks. & 1.76 & 1.16 & 1.24 & 1.37 & $\begin{array}{l}A>B, C \\
D\end{array}$ & 1.50 & 1.74 & 1.36 & 2.00 & $A, C<D$ \\
\hline $\begin{array}{l}\text { e. Har været utilfredse } \\
\text { med virks. klagebeh. }\end{array}$ & 1.47 & 1.03 & 1.15 & 1.20 & $A>B, C$ & 1.50 & 1.46 & 1.19 & 1.52 & Ingen \\
\hline $\begin{array}{l}\text { f. Har ytret tilfredshed } \\
\text { med virks. klagebeh. }\end{array}$ & 3.24 & 2.19 & 2.09 & 2.57 & $A>B, C$ & 3.23 & 3.11 & 2.25 & 3.10 & $\begin{array}{r}A, B, D> \\
C\end{array}$ \\
\hline
\end{tabular}

Noter: 5 -punkt-skala, hvor $1=<1 \% ; 2=1-2 \% ; 3=3-5 \% ; 4=5-9 \%$ og $5=10 \%$ eller mere.

Tallene $\mathrm{i}$ tabellen repræsenterer gennemsnit på den anvendte skala.

* Signifikansniveau: $5 \%$.

At klagende kunder besidder vigtig information er en gennemsnitligt mere udbredt holdning hos svenske bilforhandlere end blandt de tre øvrige brancher (spm. c). Samtlige øvrige virksomheder - i begge lande ligger dog gennemsnitligt omkring midten på den anvendte skala. Sammenfattende viser resultaterne, at virksomhederne efter deres egen opfattelse ikke er negativt indstillet over for klagende kunder.

Den nederste halvdel af tabel 4.1 viser, at virksomhederne gennemsnitligt tillægger det en middel betydning, at en investering i klagebehandling kan forrente sig. Dog tillægger bilforhandlere - i både Danmark og Sverige - dette en højere betydning end de øvrige brancher. Resultatet er i overensstemmelse med, at bilforhandlere også synes at være de mest tilbøjelige til at basere virksomhedens klagebehandling på skriftlig formulerede politikker mv. Såfremt virksomheden har anvendt ressourcer til opbygning af et klagebehandlingssystem er det ikke underligt, at virksomheden tillægger forrentningen af et sådant større betydning end virksomheder, som kun i mere begrænset omfang har anvendt sådanne ressourcer.

I tabel 4.2 er vist resultaterne af virksomhedernes stillingtagen til forskellige aspekter af kundeutilfredshed og kundeklager. Det gennemsnitlige billede af virksomhedernes vurderinger er, at kun ganske få (mindre end $2 \%$ ) kunder har været utilfredse med virksomhedens produkter/ydelser (spm. a), har været utilfredse med virksomhedens informati- 
onsafgivning/rådgivning (spm. b) eller har været utilfredse med virksomheden af anden årsag (spm. c). Der er kun ganske små brancheforskelle for disse tre spørgsmål. I Danmark har møbelforhandlerne gennemsnitligt oplevet, at en lidt større kundeandel har været utilfredse med informationsafgivning mv. sammenlignet med dagligvare- og elektronikforhandlere. Desuden har en lidt større kundeandel af anden årsag været utilfredse med møbelforhandlere end med elektronikforhandlere.

Kun en ganske lille andel af virksomhedernes kunder $(<2 \%)$ har faktisk klaget til virksomhederne (spm. d). Dette gælder i alle brancher og i begge lande, selvom det for Danmark desuden gælder, at møbelforhandlere har oplevet en lidt højere andel end de tre øvrige brancher. Det ses endvidere, at en større andel af kunderne har ytret tilfredshed med virksomhedens klagebehandling (spm. f) sammenlignet med de, som har ytret utilfredshed (spm. e). I Danmark skiller møbelforhandlerne sig desuden ud fra de øvrige brancher ved gennemsnitligt at have den største andel kunder i tilknytning til spm. e-f. I Sverige har en større kundeandel klaget til bilforhandlere sammenlignet med møbel- og dagligvareforhandlere, mens relativt færrest kunder har ytret tilfredshed med elektronikforhandlernes klagebehandling set i forhold til de tre øvrige brancher.

Tabel 4.3 Opfattet kundetilfredshed og klageadfærd (sammenlignet med virksomheder i samme branche)

\begin{tabular}{|c|c|c|c|c|c|c|c|c|c|c|}
\hline \multirow{3}{*}{$\begin{array}{l}\text { Land } \\
\text { Branche }\end{array}$} & \multicolumn{5}{|c|}{ Danmark } & \multicolumn{5}{|c|}{ Sverige } \\
\hline & Møbler & $\begin{array}{l}\text { Daglig- } \\
\text { varer }\end{array}$ & $\begin{array}{l}\text { Elek- } \\
\text { tronik }\end{array}$ & Biler & $\begin{array}{r}\text { Statis- } \\
\text { tiske } \\
\text { for- } \\
\text { skelle }^{*}\end{array}$ & Møbler & $\begin{array}{l}\text { Daglig- } \\
\text { varer }\end{array}$ & $\begin{array}{l}\text { Elek- } \\
\text { tronik }\end{array}$ & Biler & $\begin{array}{r}\text { Statis- } \\
\text { tiskefo } \\
r- \\
\text { skelle* }\end{array}$ \\
\hline & A & B & C & D & & A & B & C & D & \\
\hline \multicolumn{11}{|l|}{$\begin{array}{l}\text { Virksomhedens } \\
\text { vurdering af } \\
\text { omfanget af } \\
\text { kundetilfredshed/- } \\
\text { klager sammenlig- } \\
\text { net med branchen } \\
\text { som helhed: }\end{array}$} \\
\hline a.Utilfredse kunder & 1.59 & 2.29 & 1.67 & 1.93 & $B>A, C$ & 1.73 & 2.09 & 1.83 & 1.84 & Ingen \\
\hline b.Klagende kunder & 1.71 & 2.06 & 1.76 & 1.93 & Ingen & 1.93 & 2.23 & 2.00 & 1.90 & Ingen \\
\hline $\begin{array}{l}\text { c.Meget tilfredse } \\
\text { kunder }\end{array}$ & 2.24 & 2.23 & 2.12 & 2.30 & Ingen & 3.90 & 3.77 & 3.92 & 4.16 & Ingen \\
\hline
\end{tabular}

Noter: 5-punkt-skala, hvor 1=meget mindre; 3=gennemsnitligt og 5=meget højere.

Tallene i tabellen repræsenterer gennemsnit på den anvendte skala.

* Signifikansniveau: $5 \%$.

I tabel 4.3 er vist virksomhedernes vurderinger af omfanget af kundetilfredshed og kundeklager sammenlignet med branchen som helhed. Virksomhederne (i begge lande) mener gennemsnitligt, at de har færre utilfredse kunder sammenlignet med branchen som helhed (spm a) og ligeledes, at de har færre klagende kunder sammenlignet med branchen som helhed (spm. b). Såfremt det antages, at de undersøgte virksomheder for de enkelte brancher repræsenterer et retvisende billede af populationen af virksomheder, tyder resultatet således på, at virksomhederne enten over- 
vurderer antallet af utilfredse/klagende kunder i de enkelte brancher og/eller undervurderer virksomhedens eget omfang af utilfredse/klagende kunder $^{20}$.

En betydelig forskel imellem danske og svenske virksomheder findes med hensyn til vurderingen af omfanget af meget tilfredse kunder sammenlignet med den pågældende branche som helhed (spm. c). I Danmark mener de enkelte virksomheder gennemsnitligt, og uanset branche, at omfanget af meget tilfredse kunder er mindre end branchen som helhed. Derimod mener svenske virksomheder, uanset branche, at omfanget af meget tilfredse kunder er større end branchen som helhed.

Virksomhedernes syn på hvilke årsager, der fører til kundeklager, er vist i tabel 4.4. I begge lande vurderer møbelforhandlerne, at kundeklager navnlig skyldes, at produktet (møblet) var fejlbehæftet (spm. b) Virksomhederne er i begge lande forholdsvis enige om, at klager kun i begrænset omfang skyldes, at virksomhederne havde givet kunden mangelfuld eller forkert information (spm. a), at kunden havde urealistiske forventninger til informationer fra virksomhedernes side (spm. c), eller at kunden havde urealistiske forventninger til virksomhedens produkt (spm. d). I Sverige skiller dagligvareforhandlerne sig noget ud ved i middel omfang at mene, at klager skyldes en opstået tvist om grundlaget for handelens indgåelse (spm. e). Ingen forskelle findes blandt de danske virksomheder for dette spørgsmål.

\footnotetext{
${ }^{20}$ Dette følger af, at virksomhederne (såfremt de repræsenterer de enkelte brancher) gennemsnitligt naturligvis ikke kan ligge under gennemsnittet for de enkelte brancher.
} 
Tabel 4.4 Virksomhedernes syn på årsager til kundeklager

\begin{tabular}{|c|c|c|c|c|c|c|c|c|c|c|}
\hline \multirow{3}{*}{$\begin{array}{l}\text { Land } \\
\text { Branche }\end{array}$} & \multicolumn{5}{|c|}{ Danmark } & \multicolumn{5}{|c|}{ Sverige } \\
\hline & Møbler & $\begin{array}{l}\text { Daglig- } \\
\text { varer }\end{array}$ & $\begin{array}{l}\text { Elek- } \\
\text { tronik }\end{array}$ & Biler & $\begin{array}{r}\text { Statis- } \\
\text { tiskefo } \\
r- \\
\text { skelle* }^{*}\end{array}$ & Møbler & $\begin{array}{l}\text { Daglig- } \\
\text { varer }\end{array}$ & $\begin{array}{l}\text { Elek- } \\
\text { tronik }\end{array}$ & Biler & $\begin{array}{r}\text { Statis- } \\
\text { tiskefo } \\
r- \\
\text { skelle* }\end{array}$ \\
\hline & A & B & $C$ & D & & A & B & C & $D$ & \\
\hline $\begin{array}{l}\text { Angiv i hvilket } \\
\text { omfang klagerne } \\
\text { efter jeres } \\
\text { mening kan } \\
\text { tilskrives: }\end{array}$ & & & & & & & & & & \\
\hline $\begin{array}{l}\text { a. At I havde } \\
\text { givet kunden } \\
\text { mangelfuld eller } \\
\text { forkert infor- } \\
\text { mation }\end{array}$ & 1.59 & 1.77 & 2.00 & 2.00 & Ingen & 1.70 & 2.03 & 1.53 & 2.52 & $A, C<D$ \\
\hline $\begin{array}{l}\text { b. At produktet } \\
\text { eller ydelsen var } \\
\text { fejlbehæftet }\end{array}$ & 3.29 & 2.74 & 2.91 & 2.30 & $A>D$ & 3.13 & 2.40 & 2.50 & 2.74 & $A>B$ \\
\hline $\begin{array}{l}\text { c. At kunden } \\
\text { havde urealisti- } \\
\text { ske forventninger } \\
\text { til informationer } \\
\text { fra jeres side }\end{array}$ & 2.38 & 1.61 & 2.27 & 2.70 & $A, D>B$ & 2.00 & 2.29 & 2.06 & 1.97 & Ingen \\
\hline $\begin{array}{l}\text { d. At kunden } \\
\text { havde urealisti- } \\
\text { ske forventninger } \\
\text { til jeres produkt } \\
\text { eller ydelse }\end{array}$ & 2.47 & 1.81 & 2.58 & 2.73 & $B<C, D$ & 2.20 & 2.31 & 2.31 & 2.45 & Ingen \\
\hline $\begin{array}{l}\text { e. At der opstod } \\
\text { tvist om grundla- } \\
\text { get for handelens } \\
\text { indgåelse (f.eks. } \\
\text { tvist vedrørende } \\
\text { kontrakt el.lign.) }\end{array}$ & 2.32 & 1.74 & 1.88 & 1.50 & Ingen & 1.80 & 3.00 & 2.06 & 1.97 & $\begin{array}{r}B>A, C, \\
D\end{array}$ \\
\hline
\end{tabular}

Noter: 5-punkt-skala, hvor $1=i$ meget lille omfang og $5=i$ meget stort omfang.

Tallene i tabellen repræsenterer gennemsnit på den anvendte skala.

* Signifikansniveau: $5 \%$.

I øverste halvdel tabel 4.5 er angivet virksomhedernes vurderinger af, i hvilket omfang utilfredse kunder kan anses at have en række forskellige konsekvenser for virksomhederne. Generelt er samtlige virksomhederne enige om, at utilfredse kunder i middel, eller større, omfang vil kunne resultere $i$, at den enkelte virksomhed får et dårligt omdømme (spm. c). I Danmark anlægger navnlig bilforhandlere en sådan vurdering, mens der ingen statistiske forskelle findes blandt de svenske virksomheder for dette spørgsmål. Både danske og svenske virksomheder er desuden i middel omfang bekymrede for, at utilfredse kunder kan føre til tab af markedsandel (spm. a). Også her er danske bilforhandlere de mest bekymrede, mens der ikke kan påvises nogle forskelle imellem de svenske virksomheder. Virksomhederne mener - $\mathrm{i}$ begge lande og i alle brancher - $\mathrm{i}$ lidt mere begrænset omfang, at der skal ofres ressourcer på klagebehandling som følge af utilfredse kunder (spm. b). 
Tabel 4.5 Opfattede konsekvenser af kundeutilfredshed

\begin{tabular}{|c|c|c|c|c|c|c|c|c|c|c|}
\hline Land & Danmark & & & & & Sverige & & & & \\
\hline Branche & Møbler & $\begin{array}{l}\text { Daglig- } \\
\text { varer }\end{array}$ & $\begin{array}{l}\text { Elek- } \\
\text { tronik }\end{array}$ & Biler & $\begin{array}{r}\text { Statis- } \\
\text { tiske } \\
\text { for- } \\
\text { skelle* }^{\star}\end{array}$ & Møbler & $\begin{array}{l}\text { Daglig- } \\
\text { varer }\end{array}$ & $\begin{array}{l}\text { Elek- } \\
\text { tronik }\end{array}$ & Biler & $\begin{array}{r}\text { Statis- } \\
\text { tiske } \\
\text { for- } \\
\text { skelle* }^{*}\end{array}$ \\
\hline \multicolumn{11}{|l|}{$\begin{array}{l}\text { Vurder i hvilket } \\
\text { omfang utilfredse } \\
\text { kunder kan have } \\
\text { følgende konse- } \\
\text { kvenser for virks.: }\end{array}$} \\
\hline $\begin{array}{l}\text { a. Vi mister } \\
\text { markedsandel }\end{array}$ & 2.85 & 3.32 & 3.39 & 3.80 & $A<D$ & 2.60 & 2.71 & 3.03 & 2.87 & Ingen \\
\hline $\begin{array}{l}\text { b. Vi skal ofre } \\
\text { ressourcer på } \\
\text { klagebehandling }\end{array}$ & 2.76 & 2.06 & 2.45 & 2.67 & $A>B$ & 2.37 & 2.03 & 2.36 & 2.90 & $B<D$ \\
\hline $\begin{array}{l}\text { c. Vi får dårligt } \\
\text { omdømme }\end{array}$ & 3.44 & 2.97 & 3.42 & 3.97 & $B<D$ & 3.10 & 3.26 & 3.06 & 3.45 & Ingen \\
\hline $\begin{array}{l}\text { Vurder hvor ofte- } \\
\text { utilfredse kunder } \\
\text { generelt har } \\
\text { følgende reaktio- } \\
\text { ner b }\end{array}$ & --- & --- & -- & $=-$ & --- & ---- & -- & --- & $=-$ & --- \\
\hline $\begin{array}{l}\text { a. Kunden er } \\
\text { utilfreds, men } \\
\text { handler stadig hos } \\
\text { os }\end{array}$ & 3.41 & 3.29 & 3.70 & 3.60 & Ingen & 3.37 & 3.46 & 3.28 & 3.39 & Ingen \\
\hline $\begin{array}{l}\text { b. Kunden vil ikke } \\
\text { fremover handle } \\
\text { hos os }\end{array}$ & 1.91 & 1.58 & 1.48 & 1.80 & Ingen & 1.73 & 1.63 & 1.81 & 1.94 & Ingen \\
\hline $\begin{array}{l}\text { c. Kunden vil ikke } \\
\text { fremover handle } \\
\text { hos os og 'sladrer' } \\
\text { desuden til venner } \\
\text { og bekendte }\end{array}$ & 1.94 & 1.65 & 1.64 & 1.80 & Ingen & 2.03 & 1.66 & 2.08 & 2.32 & $B<D$ \\
\hline $\begin{array}{l}\text { d. Kunden klager } \\
\text { til os }\end{array}$ & 3.38 & 2.16 & 2.48 & 3.07 & $\begin{array}{r}A>B, C ; \\
B<D\end{array}$ & 3.60 & 3.66 & 3.19 & 3.94 & $C<D$ \\
\hline $\begin{array}{l}\text { e. Kunden klager } \\
\text { til os via tredje- } \\
\text { mand }\end{array}$ & 1.15 & 1.26 & 1.18 & 1.10 & Ingen & 1.00 & 1.09 & 1.28 & 1.06 & $\begin{array}{r}A, B, D< \\
C\end{array}$ \\
\hline
\end{tabular}

Noter:

${ }^{a} 5$-punkt-skala, hvor $1=i$ meget lille omfang og $5=i$ meget stort omfang.

b 5 -punkt-skala, hvor $1=$ meget sjældent og $5=$ =meget ofte.

Tallene i tabellen repræsenterer gennemsnit på den anvendte skala.

* Signifikansniveau: $5 \%$.

I nederste halvdel af tabel 4.5 er vist virksomhedernes vurderinger af kundereaktioner som følge af utilfredshed. Et markant resultat er, at samtlige virksomheder - $\mathrm{i}$ begge lande - angiver, at kunden kun sjældent klager til virksomheden via tredjemand (spm. e), mens de anser det for noget mere hyppigt, at kunden klager direkte til virksomheden (spm. d). Interessant er det også, at virksomhederne er enige om, at selv utilfredse kunder vil være tilbøjelige til fortsat at handle hos virksomheden (spm. a og b). 


\subsection{Konceptuelle sammenhænge}

Spørgsmålene i tabellerne 4.1 til 4.5 ovenfor kan også betragtes som målevariable for en række underliggende teoretiske koncepter, som har betydning for beskrivelsen af virksomhedens complaint management system. F.eks. kan de tre spørgsmål i den øverste del af tabel 4.1 (spørgsmålene a-c) tilsammen siges at udgøre en måling af konceptet 'virksomhedens overordnede syn på klagebehandling'. Tilsvarende kan de fem spørgsmål i den midterste del af tabel 4.1 tilsammen betragtes som en måling af konceptet 'virksomhedens konkrete syn på klagebehandling'. Ved anvendelse af en statistisk teknik kaldet Lisrel (linear structural relationship modeling) kan det nu undersøges:

Om de respektive underliggende spørgsmål (målevariable) er pålidelige repræsentanter for det betragtede teorikoncept (vha. konfirmativ faktoranalyse). Hvis ja kan herefter undersøges:

Om der kan påvises sammenhænge imellem koncepterne (vha. simul$\tan$ lineær regression).

I figur 4.1 nedenfor er opstillet en referenceramme, som angiver mulige sammenhænge imellem i alt fire teoretiske koncepter. Med referencerammen som udgangspunkt undersøges det, hvor vidt der i datamaterialet kan påvises sådanne (på forhånd antagede mulige) sammenhænge imellem koncepterne.

I alt seks mulige sammenhænge imellem koncepterne er vist i referencerammen i figur 4.1. Af disse er fire sammenhænge stabile imellem landene. I begge lande har virksomhedernes oplevede 'kundeutilfredshed' en signifikant effekt på virksomhedernes 'konkrete syn på klagende kunder'. Jo flere utilfredse kunder virksomhederne oplever, jo mere tilbøjelige er de til at opfatte klagende kunder negativt (dvs. som besværlige mv.). De 'opfattede konsekvenser af kundeutilfredshed' har i begge lande desuden en betydning for virksomhedernes 'konkrete syn på klagende kunder'. Jo mere negativt virksomhederne opfatter konsekvenserne af kundeutilfredshed jo mere negativt et syn på klagende kunder udvikles. 'Opfattede konsekvenser af kundeutilfredshed' har derimod kun i Danmark en (positiv) betydning for virksomhedernes 'overordnede syn på klagebehandling'. 
Figur 4.1 Sammenhænge imellem syn på klagebehandling, konsekvenser af klager samt kundeutilfredshed

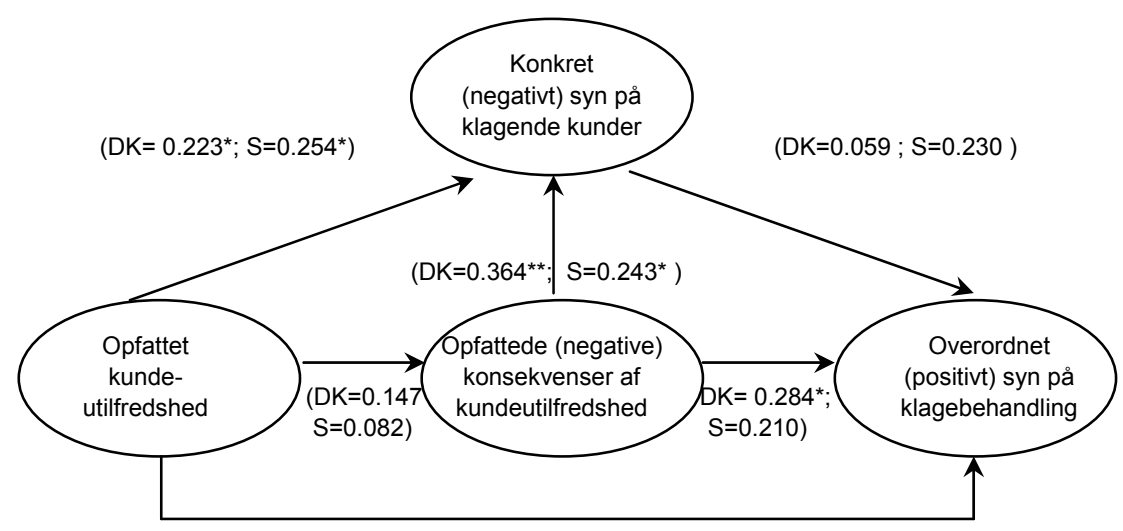

$\left(\mathrm{DK}=0.364^{*} ; \mathrm{S}=0.096\right)$

Noter. Lisrel-model (dvs. kombination af konfirmativ faktoranalyse og simultan lineær regression).

For modellens målevariable mv. henvises til appendix A.

De angivne koefficienter er standardiserede beta-koefficienter, som kan variere fra -1 til 1.

**: P-værdi<0.01.

*: P-værdi<0.05

I Danmark, men ikke i Sverige, har den oplevede 'kundeutilfredshed' en positiv betydning for virksomhedernes 'overordnede syn på klagebehandling'.

\subsection{Virksomhedsprofiler}

Med udgangspunkt $\mathrm{i}$ indholdet af virksomhedernes overordnede syn på klagehåndtering er virksomhederne i både Danmark og Sverige nedenfor opdelt i to grupper ${ }^{21}$ (tabel 4.6).

I Danmark skiller 36 virksomheder (gruppe 2) sig ud ved gennemsnitligt at have en signifikant højere score på de tre undersøgte aspekter (a-c, jf. tabel 4.6) sammenlignet med undersøgelsens øvrige 92 virksomheder (gruppe 1). I Sverige skiller 57 virksomheder (gruppe 2) sig ud ved gennemsnitligt at have en signifikant højere score på de tre undersøgte aspekter (a-c, jf. tabel 4.6) sammenlignet med undersøgelsens øvrige 75 virksomheder (gruppe 1).

${ }^{21}$ Ved hjælp af klyngeanalyse. 
Tabel 4.6 Profilering af virksomheder med hensyn til overordnet syn på klagebehandling

\begin{tabular}{|c|c|c|c|c|}
\hline \multirow[b]{2}{*}{ Gruppe } & \multicolumn{2}{|c|}{ Danmark } & \multicolumn{2}{|c|}{ Sverige } \\
\hline & Gruppe $1 n=92$ & Gruppe $2 n=36$ & Gruppe $1 n=75$ & Gruppe $2 n=57$ \\
\hline \multicolumn{5}{|l|}{$\begin{array}{l}\text { Angiv, i hvilket omfang flg. aspekter indgår i virks. } \\
\text { klagehåndteringa: }\end{array}$} \\
\hline a. Klagebehandling opfattes som et strategisk værktøj & 1.29 & 3.25 & 1.37 & 4.02 \\
\hline $\begin{array}{l}\text { b. Topledelsen engagerer sig mere eller mindre i } \\
\text { virks. daglige klagebehandling }\end{array}$ & 2.64 & 4.58 & 2.37 & 4.11 \\
\hline $\begin{array}{l}\text { c. Virks. klage- behandling er baseret på skriftligt } \\
\text { formulerede politikker, som specificerer procedurer } \\
\text { mv. for virks. klagebehandling }\end{array}$ & 1.07 & 2.25 & 1.28 & 2.84 \\
\hline \multicolumn{5}{|l|}{$\begin{array}{l}\text { Karakteristika for virksomhedsgrupperinger } \\
\text { (statistiske forskelle fremhævet med fed-kursiv) }\end{array}$} \\
\hline 1. Antal ansatte & 16.03 & 31.44 & 12.08 & 46.42 \\
\hline 2. Overskudsgrad & 8.90 & 10.17 & 7.95 & 4.81 \\
\hline 3. Omsætning i seneste regnskabsår (mill. kr.) & 24.6 & 72.8 & 27.7 & 104.4 \\
\hline 4. Antal år virksomhedsenheden har eksisteret & 34.8 & 31.8 & 24.68 & 70.25 \\
\hline 5. Opfattet kundeutilfredshed & 1.44 & 1.81 & 1.85 & 1.81 \\
\hline $\begin{array}{l}\text { 6. Antal utilfredse/klagende kunder sammenlignet } \\
\text { med branchen som helhed }\end{array}$ & 1.90 & 1.75 & 1.83 & 2.11 \\
\hline
\end{tabular}

Noter:

a : 5-punkt-skala, hvor 1=i meget lille omfang og 5=i meget stort omfang

Tallene i tabellen repræsenterer gennemsnit på den anvendte skala.

Forskellen imellem gruppe 1 og 2 er , for både Danmark og Sverige, signifikant forskellig fra 0

(signifikansniveau $5 \%$ ) for karakteristikaene a-c.

Fælles for Danmark og Sverige er, at virksomhederne i gruppe 2 gennemsnitligt er større end virksomhederne i gruppe 1. I Danmark skiller gruppe 2 virksomhederne sig ud med hensyn til omsætning pr. år, mens de svenske gruppe 2 virksomheder adskiller sig fra gruppe 1 virksomhederne både med hensyn til antal ansatte og med hensyn til omsætning pr. år. De danske gruppe 2 virksomheder oplever desuden en signifikant større kundeutilfredshed end gruppe 1 virksomhederne. Dette resultat er helt $\mathrm{i}$ overensstemmelse med Lisrel-modellen (jf. figur 4.1 ovenfor), som også viste en positiv sammenhæng imellem kundeutilfredshed og overordnet syn på klagebehandling. 


\section{Klageopfordring}

I tabel 5.1 er angivet i hvilket omfang virksomhederne anvender en række forskellige klageopfordringstiltag. Af tabellen fremgår en række markante træk - både imellem brancher og imellem lande. I Danmark skiller møbelbranchen sig ud ved at anvende hovedparten af tiltagene i større omfang end de øvrige brancher. Tendensen er, at møbelbranchen gennemgående befinder sig lidt over midten på den anvendte skala, mens de

Tabel 5.1 Virksomhedernes opfordringer til kundeklager

\begin{tabular}{|c|c|c|c|c|c|c|c|c|c|c|}
\hline \multirow{3}{*}{ Branche } & \multicolumn{5}{|c|}{ Danmark } & \multicolumn{5}{|c|}{ Sverige } \\
\hline & Møbler & $\begin{array}{l}\text { Daglig- } \\
\text { varer }\end{array}$ & $\begin{array}{l}\text { Elek- } \\
\text { tronik }\end{array}$ & Biler & $\begin{array}{r}\text { Statis- } \\
\text { tiske } \\
\text { for- } \\
\text { skelle* }^{*}\end{array}$ & Møbler & $\begin{array}{c}\text { Daglig- } \\
\text { varer }\end{array}$ & $\begin{array}{l}\text { Elek- } \\
\text { tronik }\end{array}$ & Biler & $\begin{array}{r}\text { Statis- } \\
\text { tiske } \\
\text { for- } \\
\text { skelle* }\end{array}$ \\
\hline & A & $\mathrm{B}$ & $C$ & $\mathrm{D}$ & & $\mathrm{A}$ & $\mathrm{B}$ & $C$ & $\mathrm{D}$ & \\
\hline \multicolumn{11}{|l|}{$\begin{array}{l}\text { Angiv, i hvilket } \\
\text { omfang I opfordrer } \\
\text { jeres kunder til at } \\
\text { klage ved anven- } \\
\text { delse af: }\end{array}$} \\
\hline $\begin{array}{l}\text { a. løjnefaldende } \\
\text { opslag i butikker og } \\
\text { kontorer }\end{array}$ & 3.24 & 2.23 & 2.58 & 2.43 & Ingen & 3.33 & 3.09 & 3.25 & 3.94 & Ingen \\
\hline $\begin{array}{l}\text { b. Tydelige og } \\
\text { fremhævede } \\
\text { indrykninger i } \\
\text { kataloger }\end{array}$ & 2.88 & 2.10 & 2.30 & 2.43 & Ingen & 3.13 & 3.77 & 2.78 & 3.68 & Ingen \\
\hline $\begin{array}{l}\text { c. Henvisninger i } \\
\text { litteratur og } \\
\text { instruktionsbøger }\end{array}$ & 3.38 & 2.03 & 2.45 & 1.97 & $A>B, D$ & 3.47 & 4.17 & 3.11 & 3.87 & $B>C$ \\
\hline $\begin{array}{l}\text { d. Meddelelser på } \\
\text { fakturaer, regnin- } \\
\text { ger, ordresedler og } \\
\text { kvitteringer }\end{array}$ & 3.56 & 1.94 & 2.64 & 2.97 & $A, D>B$ & 3.13 & 3.77 & 3.61 & 3.74 & Ingen \\
\hline $\begin{array}{l}\text { e. Notitser på web- } \\
\text { sider }\end{array}$ & 3.29 & 2.06 & 2.45 & 2.27 & $A>B$ & 2.77 & 3.86 & 3.17 & 3.81 & Ingen \\
\hline $\begin{array}{l}\text { f. Tilbud om } \\
\text { deltagelse i } \\
\text { lodtrækning }\end{array}$ & 3.47 & 2.00 & 2.79 & 2.43 & $A>B$ & 2.83 & 4.06 & 3.92 & 4.23 & $A<D$ \\
\hline $\begin{array}{l}\text { g. Opsætning af } \\
\text { fysiske klagebrev- } \\
\text { kasser }\end{array}$ & 3.79 & 2.10 & 2.73 & 2.60 & $A>B, D$ & 2.83 & 4.23 & 3.97 & 4.61 & $\begin{array}{r}A<B, C, \\
D\end{array}$ \\
\hline $\begin{array}{l}\text { h. Annoncering } \\
\text { linformation om } \\
\text { klageadgang i } \\
\text { brochurer el.lign. }\end{array}$ & 3.35 & 2.10 & 2.33 & 2.73 & $A>B$ & 2.73 & 3.71 & 3.50 & 4.00 & $A<D$ \\
\hline $\begin{array}{l}\text { i. Gratis telefon- } \\
\text { nummer }\end{array}$ & 3.85 & 2.10 & 2.70 & 2.67 & $\begin{array}{r}A>B, C, \\
D\end{array}$ & 3.17 & 4.17 & 3.72 & 4.39 & $A<D$ \\
\hline
\end{tabular}

Noter: 5-punkt-skala, hvor 1=i meget lille omfang og 5=i meget stort omfang.

Tallene i tabellen repræsenterer gennemsnit på den anvendte skala.

* Signifikansniveau: $5 \%$. 
øvrige tre brancher gennemgående befinder sig lidt under midten på skalaen. Navnlig opsætning af fysiske klagebrevkasser (spm. g) og gratis telefonnummer (spm. i) synes at være populære klageopfordringstiltag i møbelbranchen.

Tabel 5.2 Virksomhedernes tillagte betydning af klageopfordringstiltag

\begin{tabular}{|c|c|c|c|c|c|c|c|c|c|c|}
\hline \multirow{3}{*}{ Branche } & \multicolumn{5}{|c|}{ Danmark } & \multicolumn{5}{|c|}{ Sverige } \\
\hline & Møbler & $\begin{array}{r}\text { Dag- } \\
\text { ligva- } \\
\text { rer }\end{array}$ & $\begin{array}{l}\text { Elek- } \\
\text { tronik }\end{array}$ & Biler & $\begin{array}{r}\text { Statis- } \\
\text { tiske- } \\
\text { forskel- } \\
l e^{*}\end{array}$ & Møbler & $\begin{array}{l}\text { Dag- } \\
\text { ligva- } \\
\text { rer }\end{array}$ & $\begin{array}{l}\text { Elek- } \\
\text { tronik }\end{array}$ & Biler & $\begin{array}{r}\text { Statis- } \\
\text { tiske- } \\
\text { for- } \\
\text { skelle* }\end{array}$ \\
\hline & A & B & C & $\mathrm{D}$ & & $\mathrm{A}$ & $\mathrm{B}$ & C & $D$ & \\
\hline \multicolumn{11}{|l|}{$\begin{array}{l}\text { Angiv, i hvilket } \\
\text { omfang I tillægger } \\
\text { følgende aspekter } \\
\text { betydning i virksom- } \\
\text { hedens klagehåndte- } \\
\text { ring: }\end{array}$} \\
\hline $\begin{array}{l}\text { a. At have fysiske } \\
\text { klagebrevkasser }\end{array}$ & 1.18 & 1.39 & 1.03 & 1.07 & $B>C$ & 1.33 & 2.11 & 1.47 & 1.48 & $\begin{array}{r}B>A, C, \\
D\end{array}$ \\
\hline $\begin{array}{l}\text { b. At have personale, } \\
\text { der kun modtager } \\
\text { klager }\end{array}$ & 1.59 & 1.13 & 1.06 & 1.37 & $A>B, C$ & 2.13 & 1.29 & 1.69 & 1.84 & $A>B$ \\
\hline $\begin{array}{l}\text { c. At have personale, } \\
\text { der også modtager } \\
\text { klager }\end{array}$ & 3.09 & 1.97 & 2.70 & 2.17 & $A>B, D$ & 3.47 & 3.89 & 3.28 & 3.48 & Ingen \\
\hline $\begin{array}{l}\text { d. Notitser på web- } \\
\text { sider }\end{array}$ & 1.53 & 1.06 & 1.30 & 1.17 & $A>B, D$ & 1.58 & 1.40 & 1.83 & 1.48 & Ingen \\
\hline $\begin{array}{l}\text { e. At have skiltning } \\
\text { der viser, hvordan } \\
\text { kunder kan klage }\end{array}$ & 1.50 & 1.32 & 1.27 & 1.17 & Ingen & 1.70 & 1.86 & 1.72 & 1.48 & Ingen \\
\hline $\begin{array}{l}\text { f. Specielt gratis } \\
\text { klagetelefonnummer }\end{array}$ & 1.15 & 1.16 & 1.06 & 1.17 & Ingen & 1.27 & 1.23 & 1.61 & 1.29 & Ingen \\
\hline $\begin{array}{l}\text { g. Speciel email- } \\
\text { adresse til klager }\end{array}$ & 1.18 & 1.06 & 1.12 & 1.23 & Ingen & 1.30 & 1.46 & 1.75 & 1.52 & Ingen \\
\hline $\begin{array}{l}\text { h. At have en fysisk } \\
\text { skranke kun til } \\
\text { afgivning af klager }\end{array}$ & 1.18 & 1.00 & 1.00 & 1.17 & Ingen & 1.07 & 1.20 & 1.50 & 1.10 & $C>A, D$ \\
\hline $\begin{array}{l}\text { i. At have en fysisk } \\
\text { skranke også til } \\
\text { afgivning af klager }\end{array}$ & 1.41 & 1.03 & 1.36 & 1.50 & $B<D$ & 1.77 & 2.29 & 2.25 & 2.06 & Ingen \\
\hline $\begin{array}{l}\text { j. At fremhæve } \\
\text { klageadgang i } \\
\text { kataloger }\end{array}$ & 1.24 & 1.06 & 1.12 & 1.10 & Ingen & 1.60 & 1.14 & 1.67 & 1.13 & $\begin{array}{l}A>B, D ; \\
C>B, D\end{array}$ \\
\hline $\begin{array}{l}\text { k. At henvise til } \\
\text { klageadgang i } \\
\text { litteratur og instrukti- } \\
\text { onsbøger }\end{array}$ & 1.18 & 1.10 & 1.24 & 1.53 & $B<D$ & 1.53 & 1.14 & 2.06 & 1.52 & $\begin{array}{r}C>A, B \\
D\end{array}$ \\
\hline $\begin{array}{l}\text { I. Meddelelser på } \\
\text { fakturaer og regnin- } \\
\text { ger }\end{array}$ & 2.12 & 1.16 & 1.76 & 2.23 & $\begin{array}{c}A>B \\
B<D\end{array}$ & 2.03 & 1.54 & 2.03 & 1.94 & Ingen \\
\hline $\begin{array}{l}\text { m. Tilbud om delta- } \\
\text { gelse i lodtrækning }\end{array}$ & 1.18 & 1.23 & 1.03 & 1.20 & Ingen & 1.07 & 1.29 & 1.19 & 1.00 & $B>D$ \\
\hline
\end{tabular}

Noter: 5-punkt-skala, hvor 1=i meget lille omfang og 5=i meget stort omfang.

Tallene $\mathrm{i}$ tabellen repræsenterer gennemsnit på den anvendte skala.

* Signifikansniveau: $5 \%$.

I Sverige er udbredelsen af klageopfordringstiltag noget større end i Danmark. Svarende ligger gennemsnitligt, blandt alle de undersøgte svenske 
brancher, gennemgående over midten på skalaen. I modsætning til Danmark skiller den svenske møbelbranche sig ud ved for fire af tiltagene (spm. f-i) at ligge lavere end en eller flere af de øvrige brancher. Anvendelsen af disse tiltag er derimod gennemgående lidt mere udbredte i den svenske bilbranche end i de øvrige brancher.

I tabel 5.2 er vist, hvilken betydning virksomhederne tillægger en række klageopfordringstiltag i forbindelse med deres klagehåndtering. Det generelle billede er, at både danske og svenske virksomheder - i alle brancher - kun tillægger anvendelsen af klageopfordringstiltag ringe betydning. I Danmark, men navnlig i Sverige, skiller spm. c (at have personale, der også modtager klager) sig ud ved af virksomhederne at blive tillagt lidt højere gennemsnitlige betydning end resten af tiltagene. I Danmark er der desuden en tendens til, at møbelforhandlere tillægger klageopfordringstiltag en lidt højere betydning end de øvrige brancher, mens svenske elektronikforhandlere skiller sig ud ved at tillægge enkelte tiltag en lidt højere betydning end de øvrige brancher (jf. spm. h og k).

Man kan på forhånd formode, at der vil kunne være en sammenhæng imellem virksomhedernes faktiske opfordringer til kundeklager og den betydning de tillægger sådanne opfordringer. Således at i jo højere grad virksomhederne anser klageopfordringer som betydningsfulde i jo højere grad vil virksomhederne være tilbøjelige til faktisk at iværksætte sådanne tiltag.

Med henblik på at undersøge dette forhold blev som repræsentanter for begge dimensioner (henholdsvis 'opfordringer til kundeklager' og 'tillagt betydning af klageopfordringstiltag') anvendt de spørgsmål, som indgår i henholdsvis tabel 5.1 og 5.2. Dette var muligt, da gennemførte skala-pålidelighedstest viste, at samtlige spørgsmål pålideligt kunne anses som repræsentanter for dimensionerne ${ }^{22}$.

De gennemførte korrelationstests viste for Sverige, at der ikke kunne påvises nogen statistisk sammenhæng. Den statistiske usikkerhed var i alle tilfælde $>50 \%$; dvs. dette gjaldt både når der blev set på de enkelte lande under ét, og når landene blev opdelt på brancher. For Danmark fandtes imidlertid en positiv sammenhæng (korrelationskoefficient 0.203 , $\mathrm{p}$-værdi $=0.022)^{23}$ imellem de to dimensioner, når alle brancher blev betragtet under ét. Sammenhængen dækker dog over, at der ikke kunne påvises nogen sammenhæng for møbel- og dagligvareforhandlere, mens

${ }^{22}$ Anvendt skala-pålidelighedstest: Cronbachs alpha. Alpha-værdien var for 'faktisk klageopfordring' 0.97 (DK) og 0.96 (S), For 'tillagt betydning af klageopfordring' var alpha-værdierne 0.82 (DK) og 0.78 (S). I samtlige tilfælde er alpha-værdierne betydeligt højere end den normalt accepterede værdi på 0.70 , ligesom alpha-værdierne $\mathrm{i}$ ingen af tilfældene ville forandre sig nævneværdigt, såfremt et eller flere spørgsmål blev elimineret fra dimensionerne.

${ }^{23}$ Korrelationskoefficienten er et mål for graden af lineær sammenhæng imellem to variable (i dette tilfælde 'tillagt betydning af klageopfordring' og 'faktisk klageopfordring') og kan variere fra 1 til +1 , hvor -1 er udtryk for en perfekt negativ lineær sammenhæng og +1 er udtryk for en perfekt positiv lineær sammenhæng. P-værdien udtrykker den statistiske sandsynlighed for, at den beregnede korrelationskoefficient er lig med 0 . En p-værdi på eksempelvis 0.022 betyder således, at man med $2.2 \%$ usikkerhed ikke kan afvise, at der er en lineær sammenhæng imellem variablene. Som tidligere nævnt accepteres normalt en usikkerhed på op til $5 \%$. 
sammenhængen (korrelationskoefficienten) for elektronikforhandlere var 0.458 (p-værdi=0.007) og for bilforhandlere 0.401 ( $p$-værdi=0.028). 


\section{Klagebehandling og resultater af klagebehandling}

\begin{tabular}{|c|c|c|c|c|c|c|c|c|c|c|}
\hline \multirow{3}{*}{ Branche } & \multicolumn{5}{|c|}{ Danmark } & \multicolumn{5}{|l|}{ Sverige } \\
\hline & $\begin{array}{l}\text { Møb- } \\
\text { ler }\end{array}$ & $\begin{array}{l}\text { Dag- } \\
\text { lig- } \\
\text { varer }\end{array}$ & $\begin{array}{l}\text { Elek- } \\
\text { tronik }\end{array}$ & Biler & $\begin{array}{r}\text { Statis- } \\
\text { tiske } \\
\text { forske } \\
\text { lle }^{*}\end{array}$ & $\begin{aligned} \text { Møb- } \\
\text { ler }\end{aligned}$ & $\begin{array}{l}\text { Dag- } \\
\text { lig- } \\
\text { varer }\end{array}$ & $\begin{array}{l}\text { Elek- } \\
\text { tronik }\end{array}$ & Biler & $\begin{array}{r}\text { Statis- } \\
\text { tiske } \\
\text { for- } \\
\text { skelle* }^{*}\end{array}$ \\
\hline & $\mathrm{A}$ & $\mathrm{B}$ & $C$ & $\mathrm{D}$ & & A & B & C & D & \\
\hline $\begin{array}{l}\text { Angiv, i hvilket omfang } \\
\text { følgende aspekter indgår i } \\
\text { virks. klagehåndtering: }\end{array}$ & & & & & & & & & & \\
\hline $\begin{array}{l}\text { a. Der er eksplicit allokeret } \\
\text { ressourcer til klagehåndte- } \\
\text { ringsaktiviteter }\end{array}$ & 1.50 & 1.16 & 1.18 & 1.63 & $B<D$ & 1.50 & 1.29 & 1.44 & 2.29 & $\begin{array}{r}A, B, C< \\
D\end{array}$ \\
\hline $\begin{array}{l}\text { b. Intern personaleuddan- } \\
\text { nelse i klagehåndtering }\end{array}$ & 2.00 & 1.26 & 1.67 & 1.90 & $\begin{array}{l}A>B ; \\
B<D\end{array}$ & 2.00 & 2.09 & 1.75 & 2.55 & $C<D$ \\
\hline $\begin{array}{l}\text { c. Instruktion af personale i } \\
\text { klagepolitikker }\end{array}$ & 2.29 & 2.00 & 1.91 & 2.33 & Ingen & 2.57 & 3.20 & 2.47 & 3.19 & $B>C$ \\
\hline $\begin{array}{l}\text { d. Klagemanualer eller } \\
\text { instruktioner for nyt } \\
\text { personale }\end{array}$ & 1.59 & 1.26 & 1.36 & 1.90 & $D<B, C$ & 2.00 & 2.03 & 1.69 & 2.39 & $C>D$ \\
\hline $\begin{array}{l}\text { e. Eksterne kurser for } \\
\text { personale i klagehåndte- } \\
\text { ring }\end{array}$ & 1.41 & 1.13 & 1.48 & 2.03 & $\begin{array}{r}D>A, B, \\
C\end{array}$ & 1.37 & 1.09 & 1.39 & 1.90 & $\begin{array}{r}A, B, C< \\
D\end{array}$ \\
\hline $\begin{array}{l}\text { f. Vægtning af interperso- } \\
\text { nelle kompetencer , når } \\
\text { nyt personale ansættes }\end{array}$ & 1.94 & 1.42 & 1.73 & 1.83 & Ingen & 1.63 & 1.49 & 1.58 & 2.03 & Ingen \\
\hline $\begin{array}{l}\text { g. Central samling og } \\
\text { overvàgning af klagein- } \\
\text { formation }\end{array}$ & 1.88 & 1.39 & 1.39 & 2.63 & $\begin{array}{r}D>A, B, \\
C\end{array}$ & 1.93 & 1.66 & 1.86 & 2.74 & $\begin{array}{r}A, B, C< \\
D\end{array}$ \\
\hline $\begin{array}{l}\text { h. Fremme af intern } \\
\text { klagekultur (dvs. opfor- } \\
\text { dring til personalet om at } \\
\text { klage over ledelse eller } \\
\text { andre hvis påkrævet) }\end{array}$ & 1.59 & 1.16 & 1.42 & 1.73 & $B<D$ & 1.97 & 1.94 & 2.06 & 2.52 & Ingen \\
\hline $\begin{array}{l}\text { i. Bemyndigelse til } \\
\text { frontpersonale til at } \\
\text { behandle eller afvise } \\
\text { rutine- eller mindre klager } \\
\text { hurtigt/umiddelbart? } \\
\text { (herunder godskrive beløb } \\
\text { mv.) }\end{array}$ & 2.44 & 1.71 & 1.67 & 1.93 & $A>B, C$ & 2.47 & 2.80 & 2.11 & 3.32 & $A, C<D$ \\
\hline $\begin{array}{l}\text { j. Fremme af en intern } \\
\text { "ikke-bebrejdelseskultur" } \\
\text { (dvs. ansatte i virks. bør } \\
\text { ikke bebrejde den som har } \\
\text { modtaget kritik) }\end{array}$ & 1.71 & 1.52 & 1.58 & 1.70 & Ingen & 2.27 & 2.54 & 2.50 & 3.10 & $A<D$ \\
\hline $\begin{array}{l}\text { k. Anvendelse af fastlagte } \\
\text { politikker for klagebehand- } \\
\text { ling }\end{array}$ & 2.12 & 1.58 & 1.85 & 2.37 & $B<D$ & 2.23 & 2.31 & 2.14 & 3.16 & $\begin{array}{r}A, B, C> \\
D\end{array}$ \\
\hline
\end{tabular}

Tabel fortsættes... 
Tabel 6.2. Indholdet i virksomhedernes klagehåndtering (tabel fortsat...)

\begin{tabular}{|c|c|c|c|c|c|c|c|c|c|c|}
\hline \multirow{3}{*}{ Branche } & \multicolumn{5}{|l|}{ Danmark } & \multicolumn{5}{|l|}{ Sverige } \\
\hline & Møbler & $\begin{array}{r}\text { Dagligv } \\
\text { arer }\end{array}$ & $\begin{array}{l}\text { Elek- } \\
\text { tronik }\end{array}$ & Biler & $\begin{array}{r}\text { Statis- } \\
\text { tiske } \\
\text { for- } \\
\text { skelle* }^{*}\end{array}$ & Møbler & $\begin{array}{r}\text { Dagligv } \\
\text { arer }\end{array}$ & $\begin{array}{l}\text { Elek- } \\
\text { tronik }\end{array}$ & Biler & $\begin{array}{r}\text { Statis- } \\
\text { tiske } \\
\text { for- } \\
\text { skelle* }\end{array}$ \\
\hline & A & $B$ & C & $D$ & & A & $B$ & C & $D$ & \\
\hline $\begin{array}{l}\text { Angiv, i hvilket } \\
\text { omfang følgende } \\
\text { aspekter indgår i } \\
\text { virks. klagehånd- } \\
\text { tering: }\end{array}$ & & & & & & & & & & \\
\hline $\begin{array}{l}\text { I. Definerede } \\
\text { målsætninger for } \\
\text { klagebehandling }\end{array}$ & 1.79 & 1.55 & 1.70 & 2.43 & $B, C<D$ & 1.93 & 1.74 & 2.02 & 2.94 & $\begin{array}{r}A, B, C< \\
D\end{array}$ \\
\hline $\begin{array}{l}\text { m. Defineret } \\
\text { ansvar for } \\
\text { udførelse af } \\
\text { klagebehandling }\end{array}$ & 2.26 & 1.71 & 2.15 & 2.57 & $B<D$ & 2.40 & 2.17 & 2.42 & 3.55 & $\begin{array}{r}A, B, C< \\
D\end{array}$ \\
\hline $\begin{array}{l}\text { n. Defineret } \\
\text { ansvar for } \\
\text { overvågning af } \\
\text { klagebehandling }\end{array}$ & 2.15 & 1.65 & 1.97 & 2.37 & $B<D$ & 2.27 & 1.77 & 2.19 & 3.10 & $\begin{array}{r}A, B, C< \\
D\end{array}$ \\
\hline $\begin{array}{l}\text { o. Klare specifika- } \\
\text { tioner for } \\
\text { klageregistrering }\end{array}$ & 2.21 & 1.39 & 1.76 & 2.37 & $\begin{array}{l}A>B ; \\
B<D\end{array}$ & 2.03 & 2.20 & 2.11 & 2.48 & Ingen \\
\hline $\begin{array}{l}\text { p. Løbende } \\
\text { vurdering af } \\
\text { klagesystemets } \\
\text { effektivitet og } \\
\text { målopfyldelse }\end{array}$ & 1.85 & 1.45 & 1.70 & 2.10 & $B<D$ & 1.83 & 1.71 & 1.97 & 2.42 & $B<D$ \\
\hline
\end{tabular}

Noter: 5-punkt-skala, hvor $1=i$ meget lille omfang og $5=i$ meget stort omfang.

Tallene i tabellen repræsenterer gennemsnit på den anvendte skala.

* Signifikansniveau: $5 \%$.

I tabel 6.2 ovenfor er angivet, i hvilket omfang en række forskellige aspekter indgår i virksomhedernes klagehåndtering. Det generelle billede er, at virksomhederne kun i begrænset omfang (de fleste aspekter tildeles gennemsnit, som befinder sig under midten på den anvendte skala) anvender de undersøgte aspekter i klagehåndteringen. En række statistiske forskelle imellem brancherne kan i begge lande findes på en række aspekter, men ingen brancher skiller sig ud ved gennemgående at have gennemsnit omkring, eller højere, end skala-midten. I Sverige har bilforhandlerne dog en tendens til at have en lidt højere udbredelse af klagehåndteringsaspekterne end de øvrige brancher. Kun på nogle af aspekterne (spm. i og m) ligger bilbranchen dog betragteligt over midten på skalaen.

Med henblik på at undersøge om der er forskelle blandt de undersøgte virksomheder på tvcers af brancher er nedenfor udarbejdet virksomhedsprofiler med udgangspunkt i klagehåndtering.

Virksomhedsprofiler - indhold af klagehåndtering

På basis af indholdet af virksomhedernes klagehåndtering er virksomhederne i både Danmark og Sverige opdelt i to grupper ${ }^{24}$ (tabel 6.3).

${ }^{24}$ Ved hjælp af klyngeanalyse. 
Tabel 6.3 Profilering af virksomheder med hensyn til klagehåndtering

\begin{tabular}{|c|c|c|c|c|}
\hline \multirow[b]{2}{*}{ Gruppe } & \multicolumn{2}{|c|}{ Danmark } & \multicolumn{2}{|c|}{ Sverige } \\
\hline & $\begin{array}{r}\text { Gruppe } \\
1 \mathrm{n}=99\end{array}$ & $\begin{array}{r}\text { Gruppe } \\
2 n=29\end{array}$ & $\begin{array}{r}\text { Gruppe } \\
1 \mathrm{n}=97\end{array}$ & $\begin{array}{r}\text { Gruppe } \\
2 n=35\end{array}$ \\
\hline \multicolumn{5}{|l|}{$\begin{array}{l}\text { Angiv, i hvilket omfang følgende aspekter indgår i virks. } \\
\text { klagehåndteringa: }\end{array}$} \\
\hline $\begin{array}{l}\text { a. Der er eksplicit allokeret ressourcer til klagehåndte- } \\
\text { ringsaktiviteter }\end{array}$ & 1.05 & 2.45 & 1.25 & 2.63 \\
\hline b. Intern personaleuddannelse i klagehåndtering & 1.29 & 3.14 & 1.51 & 3.69 \\
\hline c. Instruktion af personale i klagepolitikker & 1.68 & 3.69 & 2.30 & 4.40 \\
\hline d. Klagemanualer eller instruktioner for nyt personale & 1.26 & 2.41 & 1.46 & 3.54 \\
\hline e. Eksterne kurser for personale i klagehåndtering & 1.20 & 2.55 & 1.24 & 1.94 \\
\hline $\begin{array}{l}\text { f. Vægtning af interpersonelle kompetencer (kundeforstå- } \\
\text { else), når nyt personale ansættes }\end{array}$ & 1.34 & 3.07 & 1.31 & 2.69 \\
\hline g. Central samling og overvågning af klageinformation & 1.34 & 3.31 & 1.46 & 3.60 \\
\hline $\begin{array}{l}\text { h. Fremme af intern klagekultur (dvs. opfordring til } \\
\text { personalet om at klage over ledelse eller andre hvis } \\
\text { påkrævet) }\end{array}$ & 1.11 & 2.72 & 1.59 & 3.57 \\
\hline $\begin{array}{l}\text { i. Bemyndigelse til frontpersonale til at behandle eller } \\
\text { afvise rutine- eller mindre klager hurtigt/umiddelbart? } \\
\text { (herunder godskrive beløb mv.) }\end{array}$ & 1.60 & 3.14 & 2.20 & 3.94 \\
\hline $\begin{array}{l}\text { j. Fremme af en intern "ikke-bebrejdelseskultur" (dvs. } \\
\text { ansatte i virksomheden bør ikke bebrejde den som har } \\
\text { modtaget kritik) }\end{array}$ & 1.28 & 2.79 & 2.16 & 3.80 \\
\hline k. Anvendelse af fastlagte politikker for klagebehandling & 1.47 & 3.69 & 1.88 & 4.03 \\
\hline I. Definerede målsætninger for klagebehandling & 1.36 & 3.55 & 1.61 & 3.69 \\
\hline m. Defineret ansvar for udførelse af klagebehandling & 1.58 & 4.21 & 2.07 & 4.11 \\
\hline n. Defineret ansvar for overvågning af klagebehandling & 1.49 & 3.86 & 1.71 & 3.97 \\
\hline o. Klare specifikationer for klageregistrering & 1.40 & 3.72 & 1.66 & 3.71 \\
\hline $\begin{array}{l}\text { p. Løbende vurdering af klagesystemets effektivitet og } \\
\text { målopfyldelse }\end{array}$ & 1.31 & 3.34 & 1.48 & 3.34 \\
\hline \multicolumn{5}{|l|}{$\begin{array}{l}\text { Karakteristika for virksomhedsgrupperinger } \\
\text { (statistiske forskelle fremhævet med fed-kursiv) }\end{array}$} \\
\hline 1. Antal ansatte & 16.56 & 33.38 & 17.46 & 53.09 \\
\hline 2. Overskudsgrad & 14.44 & 19.08 & 7.40 & 4.34 \\
\hline 3. Omsætning i seneste regnskabsår (mill. kr.) & 27.9 & 76.5 & 46.2 & 101.4 \\
\hline 4. Klagebehandling ses som et strategisk redskab & 1.27 & 2.81 & 1.75 & 3.59 \\
\hline 5. Antal år virksomhedsenheden har eksisteret & 36.80 & 24.21 & 46.82 & 37.51 \\
\hline 6. Opfattet kundeutilfredshed & 1.40 & 2.02 & 1.89 & 1.66 \\
\hline $\begin{array}{l}\text { 7. Tillagt betydning af forrentning af klagehåndteringssy- } \\
\text { stem }\end{array}$ & 2.44 & 3.31 & 2.67 & 3.51 \\
\hline $\begin{array}{l}\text { 8. Antal utilfredse/klagende kunder sammenlignet med } \\
\text { branchen som helhed }\end{array}$ & 1.85 & 1.86 & 1.91 & 2.06 \\
\hline
\end{tabular}

Noter:

${ }^{a}:$-punkt-skala, hvor $1=i$ meget lille omfang og $5=i$ meget stort omfang

Tallene $\mathrm{i}$ tabellen repræsenterer gennemsnit på den anvendte skala.

Forskellen imellem gruppe 1 og 2 er, for både Danmark og Sverige, signifikant forskellig fra 0 (signifikansniveau 5\%) for karakteristikaene a-p.

I både Danmark og Sverige er grupperne ikke forskellige med hensyn til branche.

I Danmark skiller 29 virksomheder (gruppe 2) sig ud ved gennemsnitligt at have en signifikant højere score på samtlige de undersøgte aspekter (a$\mathrm{p}$, jf. tabel 6.3) sammenlignet med undersøgelsens øvrige 99 virksomheder (gruppe 1).

I Sverige skiller 35 virksomheder (gruppe 2) sig ud ved gennemsnitligt at have en signifikant højere score på samtlige de undersøgte aspekter 
(a-p, jf. tabel 6.3) sammenlignet med undersøgelsens øvrige 97 virksomheder (gruppe 1).

Gruppe 2 er omtrent lige stor (omfatter ca. 25\% af de adspurgte virksomheder) i Danmark og Sverige.

En række fællestræk kan findes mellem landene med hensyn til virksomhedsprofilerne i gruppe 1 og 2. I både Danmark og Sverige er gruppe 2 virksomhederne signifikant større end gruppe 1 virksomhederne hvad angår antallet ansatte. Hertil kommer, at gruppe 2 virksomhederne i større omfang opfatter klagebehandling som et strategisk redskab, ligesom de også tillægger forretningen af klagehåndteringssystemet en større betydning end gruppe 1 virksomhederne.

I Danmark er gruppe 2 virksomhederne tillige signifikant større end gruppe 1 virksomhederne med hensyn til omsætning i seneste regnskabsår. Gruppe 2 virksomhederne i Danmark har desuden eksisteret et færre antal år end gruppe 1 virksomhederne.

Virksomhedernes behandling af kundeklager - resultat af klagebehandling

I tabel 6.4 er anført, hvor stor en andel af de klagende kunder, virksomheder i gennemsnit (a) giver ubetinget medhold, (b) giver delvist medhold, (c) afviser med skriftlig begrundelse, (d) afviser umiddelbart men med mundtlig begrundelse og (e) afviser uden begrundelse. 
Tabel 6.4 Virksomhedernes behandling af kundeklager - overordnet resultat af klagebehandling

\begin{tabular}{|c|c|c|c|c|c|c|c|c|c|c|}
\hline \multirow{3}{*}{ Branche } & \multicolumn{5}{|c|}{ Danmark } & \multicolumn{5}{|c|}{ Sverige } \\
\hline & Møbler & $\begin{array}{r}\text { Dagligv } \\
\text { arer }\end{array}$ & $\begin{array}{l}\text { Elek- } \\
\text { tronik }\end{array}$ & Biler & $\begin{array}{r}\text { Statis- } \\
\text { tiske } \\
\text { for- } \\
\text { skelle* }^{*}\end{array}$ & Møbler & $\begin{array}{r}\text { Dagligv } \\
\text { arer }\end{array}$ & $\begin{array}{l}\text { Elek- } \\
\text { tronik }\end{array}$ & Biler & $\begin{array}{r}\text { Statis- } \\
\text { tiske } \\
\text { for- } \\
\text { skelle* }^{*}\end{array}$ \\
\hline & A & B & C & D & & A & B & C & D & \\
\hline \multicolumn{11}{|l|}{$\begin{array}{l}\text { Vurdér, hvor } \\
\text { stor en andel af } \\
\text { de klagende } \\
\text { kunder jeres } \\
\text { virksomhed i } \\
\text { gennemsnit: }\end{array}$} \\
\hline $\begin{array}{l}\text { a. Giver } \\
\text { ubetinget } \\
\text { medhold }\end{array}$ & 3.47 & 4.16 & 3.58 & 3.33 & $B>D$ & 3.10 & 3.11 & 2.92 & 3.16 & Ingen \\
\hline $\begin{array}{l}\text { b. Giver delvist } \\
\text { medhold }\end{array}$ & 3.06 & 3.87 & 3.30 & 3.40 & $A<B$ & 2.70 & 2.86 & 2.50 & 3.06 & Ingen \\
\hline $\begin{array}{l}\text { c. Afviser med } \\
\text { skriftlig begrun- } \\
\text { delse }\end{array}$ & 1.38 & 1.00 & 1.33 & 1.90 & $\begin{array}{r}D>A, B, \\
C\end{array}$ & 1.33 & 1.26 & 1.22 & 1.61 & $C<D$ \\
\hline $\begin{array}{l}\text { d. Afviser } \\
\text { umiddelbart } \\
\text { men med } \\
\text { mundtlig } \\
\text { begrundelse }\end{array}$ & 2.00 & 1.74 & 2.61 & 1.83 & $C>B, D$ & 1.57 & 1.63 & 1.56 & 1.97 & Ingen \\
\hline $\begin{array}{l}\text { e. Afviser uden } \\
\text { begrundelse }\end{array}$ & 1.21 & 1.00 & 1.03 & 1.03 & Ingen & 1.07 & 1.11 & 1.22 & 1.19 & Ingen \\
\hline
\end{tabular}

Noter: 5-punkt-skala, hvor $1=<1 \% ; 2=1-5 \% ; 3=6-10 \% ; 4=11-19 \%$ og $5=20 \%$ eller mere Tallene i tabellen repræsenterer gennemsnit på den anvendte skala.

* Signifikansniveau: $5 \%$.

Det ses, at kun meget få kunder ifølge virksomhederne afvises. Der er en lille tendens til, at de forholdsvis få kunder som afvises hyppigere modtager en mundtlig frem for en skriftlig begrundelse. Oftere gives kunderne dog efter virksomhedernes opfattelse enten ubetinget eller delvist medhold. Disse betragtninger er ensartede for Danmark og Sverige.

\section{Klagekompensation}

Nogle typer af klagekompensation benyttes i vidt omfang af virksomhederne (f.eks. gratis reparation eller bytning af produktet), mens andre kun benyttes i mere begrænset omfang (f.eks. aflevering af symbolsk gave til kunden eller overkompensation), jf. tabel 6.5. 
Tabel 6.5 Klagekompensation

\begin{tabular}{|c|c|c|c|c|c|c|c|c|c|c|}
\hline \multirow[b]{2}{*}{ Branche } & \multicolumn{5}{|c|}{ Danmark } & \multicolumn{5}{|c|}{ Sverige } \\
\hline & Møbler & $\begin{array}{l}\text { Daglig- } \\
\text { varer }\end{array}$ & $\begin{array}{l}\text { Elek- } \\
\text { tronik }\end{array}$ & Biler & $\begin{array}{r}\text { Statis- } \\
\text { tiske } \\
\text { for- } \\
\text { skelle }^{*}\end{array}$ & Møbler & $\begin{array}{c}\text { Daglig- } \\
\text { varer }\end{array}$ & $\begin{array}{c}\text { Elek- } \\
\text { tronik }\end{array}$ & Biler & $\begin{array}{r}\text { Statis- } \\
\text { tiske } \\
\text { for- } \\
\text { skelle* }\end{array}$ \\
\hline & A & $\mathrm{B}$ & $C$ & $\mathrm{D}$ & & A & $\mathrm{B}$ & $C$ & $D$ & \\
\hline \multicolumn{11}{|l|}{$\begin{array}{l}\text { Angiv i hvilket } \\
\text { omfang I kompen- } \\
\text { serer en kunde ved } \\
\text { hjælp af følgende } \\
\text { tiltag (f.eks. hvis der } \\
\text { er tale om fejl } \\
\text { el.lign. ved et } \\
\text { produkt): }\end{array}$} \\
\hline $\begin{array}{l}\text { a. Produktet } \\
\text { repareres gratis }\end{array}$ & 4.32 & 4.26 & 3.91 & 4.60 & $C<D$ & 4.10 & 3.15 & 3.85 & 3.68 & $A>B$ \\
\hline b. Produktet byttes & 4.06 & 4.81 & 3.58 & 3.89 & $\begin{array}{r}B>A, C \\
D\end{array}$ & 4.47 & 4.79 & 4.09 & 2.97 & $\begin{array}{r}D<A, B \text {, } \\
C ; \\
B>C\end{array}$ \\
\hline $\begin{array}{l}\text { c. Produktet byttes } \\
\text { og kunden modta- } \\
\text { ger en symbolsk } \\
\text { gave el.lign. for } \\
\text { ulejligheden }\end{array}$ & 2.11 & 1.84 & 1.50 & 1.92 & Ingen & 2.60 & 3.50 & 1.97 & 2.06 & $\begin{array}{r}B>A, C, \\
D ;\end{array}$ \\
\hline $\begin{array}{l}\text { d. Produktet byttes } \\
\text { og kunden modta- } \\
\text { ger en stor gave } \\
\text { el.lign. for ulejlighe- } \\
\text { den }\end{array}$ & 1.35 & 1.67 & 1.10 & 1.31 & $B>C$ & 1.71 & 1.87 & 1.26 & 1.52 & Ingen \\
\hline $\begin{array}{l}\text { e. Vi kompenserer } \\
\text { kunden for netop } \\
\text { det, som kunden } \\
\text { skulle have } \\
\text { modtaget }\end{array}$ & 3.24 & 4.32 & 3.43 & 3.76 & $B>A, C$ & 4.00 & 3.61 & 3.15 & 3.40 & $A>C$ \\
\hline $\begin{array}{l}\text { f. Vi kompenserer } \\
\text { kunden for det } \\
\text { besvær, det har } \\
\text { været f.eks. at } \\
\text { skulle transportere } \\
\text { sig ekstraordinært } \\
\text { til virksomheden } \\
\text { som følge af en fejl }\end{array}$ & 1.87 & 1.68 & 2.31 & 2.50 & Ingen & 3.41 & 2.67 & 2.35 & 3.26 & $\begin{array}{r}A>B, C \\
C>D\end{array}$ \\
\hline $\begin{array}{l}\text { g. Vi kompenserer } \\
\text { kunden for den } \\
\text { psykiske anstren- } \\
\text { gelse det kan være } \\
\text { at klage }\end{array}$ & 1.16 & 1.69 & 1.16 & 1.46 & $A<B$ & 2.10 & 2.00 & 1.50 & 1.73 & Ingen \\
\hline $\begin{array}{l}\text { h. Vi } \\
\text { 'overkompenserer' } \\
\text { kunden for at gøre } \\
\text { kunden opmærk- } \\
\text { som på, at vi sætter } \\
\text { pris på, at kunden } \\
\text { har tilkendegivet sin } \\
\text { utilfredshed }\end{array}$ & 1.89 & 1.71 & 1.48 & 1.94 & Ingen & 2.27 & 3.21 & 2.00 & 2.38 & $\begin{array}{r}B>A, C, \\
D\end{array}$ \\
\hline
\end{tabular}

Noter: 5-punkt-skala, hvor $1=i$ meget lille omfang og $5=i$ meget stort omfang.

Tallene i tabellen repræsenterer gennemsnit på den anvendte skala.

* Signifikansniveau: $5 \%$. 
I Danmark er det mest udbredt, at bilforhandlere reparerer produktet gratis ved en klage. Disse træk genfindes ikke hos de svenske forhandlere, hvor møbelforhandlere er statistisk set mere tilbøjelige end dagligvareforhandlere til at reparere produktet gratis (spm. a).

Det er i både Danmark og Sverige ganske udbredt blandt de undersøgte virksomheder at yde kunderne kompensation for det kunden skulle have modtaget (spm. e). Resultatet skal dog formentlig ikke forstås således, at virksomhederne adderer de forskellige kompensationsårsager ved udmøntning af kompensationen, snarere er der nok tale om en opgørelse af aspekter, som kan danne baggrund for kompensationen. Dette spørgsmål kan dog ikke besvares entydigt med baggrund i det indsamlede datagrundlag.

\section{Konceptuelle sammenhoenge}

I figur 6.1 nedenfor er opstillet en referenceramme, som angiver mulige sammenhænge imellem i alt tre teoretiske koncepter (faktisk klageopfordring, kompensation og oplevet kundetilfredshed). Med referencerammen som udgangspunkt undersøges det, hvor vidt der i datamaterialet kan påvises sådanne (på forhånd antagede mulige) sammenhænge imellem koncepterne.

I alt tre mulige sammenhænge imellem koncepterne er vist i referencerammen i figur 6.1. Af disse er én sammenhæng stabil imellem landene. I begge lande har omfanget af kompensation en signifikant positiv betydning for omfanget af oplevet kundetilfredshed. Derimod har omfanget af faktiske klageopfordringstiltag alene en positiv betydning for omfanget af kompensationstiltag blandt de undersøgte svenske virksomheder. Faktisk klageopfordring har $\mathrm{i}$ ingen af landene betydning for virksomhedernes oplevelse af kundetilfredshed.

Figur 6.1 Sammenhænge imellem klageopfordring, kompensation og kundetilfredshed

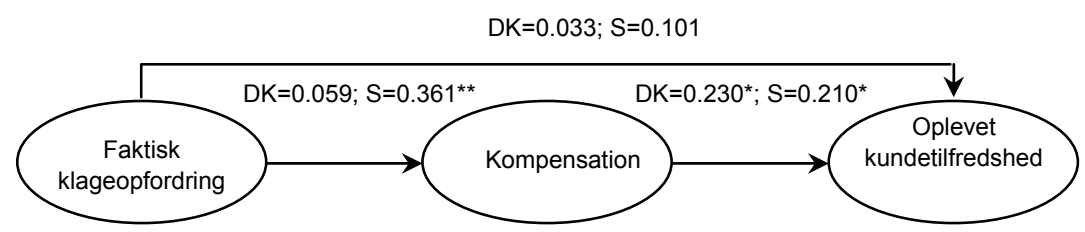

Noter. Lisrel-model (dvs. kombination af konfirmativ faktoranalyse og simultan lineær regression) I modellen forklares $11.8 \%$ (DK) henholdsvis $9.0 \%$ (S) af variationen i oplevet kundetilfredshed.

For modellens målevariable mv. henvises til appendix B.

De angivne koefficienter er standardiserede beta-koefficienter, som kan variere fra -1 til 1.

**: P-værdi<0.01

*: P-værdi<0.05 


\section{Virksomhedsprofiler}

Med udgangspunkt i omfanget af klagekompensation er virksomhederne i både Danmark og Sverige blevet opdelt i to grupper (tabel 6.6).

Tabel 6.6 Profilering af virksomheder med hensyn til klagekompensation

\begin{tabular}{|c|c|c|c|c|}
\hline \multirow[b]{2}{*}{ Gruppe } & \multicolumn{2}{|c|}{ Danmark } & \multicolumn{2}{|c|}{ Sverige } \\
\hline & $\begin{array}{r}\text { Gruppe } \\
1 \mathrm{n}=72\end{array}$ & $\begin{array}{r}\text { Gruppe } \\
2 n=56\end{array}$ & $\begin{array}{r}\text { Gruppe } \\
1 \mathrm{n}=84\end{array}$ & $\begin{array}{r}\text { Gruppe } \\
2 n=48\end{array}$ \\
\hline \multicolumn{5}{|l|}{$\begin{array}{l}\text { Angiv i hvilket omfang I kompenserer en kunde ved } \\
\text { hjælp af følgende tiltag (f.eks. hvis der er tale om fejl } \\
\text { el.lign. ved et produkt): }\end{array}$} \\
\hline a. Produktet repareres gratis & 3.85 & 4.35 & 3.29 & 4.33 \\
\hline b. Produktet byttes & 3.35 & 4.06 & 3.69 & 4.26 \\
\hline $\begin{array}{l}\text { c. Produktet byttes og kunden modtager en symbolsk } \\
\text { gave el.lign. for ulejligheden }\end{array}$ & 1.43 & 2.94 & 1.83 & 3.70 \\
\hline $\begin{array}{l}\text { d. Produktet byttes og kunden modtager en stor gave } \\
\text { el.lign. for ulejligheden }\end{array}$ & 1.05 & 1.82 & 1.15 & 2.19 \\
\hline $\begin{array}{l}\text { e. Vi kompenserer kunden for netop det, som kunden } \\
\text { skulle have modtaget }\end{array}$ & 2.70 & 4.00 & 3.42 & 3.78 \\
\hline $\begin{array}{l}\text { f. Vi kompenserer kunden for det besvær, det har været } \\
\text { f.eks. at skulle transportere sig ekstraordinært til virk- } \\
\text { somheden som følge af en fejl }\end{array}$ & 1.23 & 3.82 & 2.38 & 4.07 \\
\hline $\begin{array}{l}\text { g. Vi kompenserer kunden for den psykiske anstrengelse } \\
\text { det kan være at klage }\end{array}$ & 1.08 & 1.88 & 1.27 & 2.96 \\
\hline $\begin{array}{l}\text { h. Vi 'overkompenserer' kunden for at gøre kunden } \\
\text { opmærksom på, at vi sætter pris på, at kunden har } \\
\text { tilkendegivet sin utilfredshed }\end{array}$ & 1.28 & 2.94 & 1.67 & 3.63 \\
\hline \multicolumn{5}{|l|}{$\begin{array}{l}\text { Karakteristika for virksomhedsgrupperinger } \\
\text { (statistiske forskelle fremhævet med fed-kursiv) }\end{array}$} \\
\hline 1. Antal ansatte & 18.93 & 40.76 & 31.15 & 24.59 \\
\hline 2. Overskudsgrad & 10.75 & 10.35 & 9.08 & 6.59 \\
\hline 3. Omsætning i seneste regnskabsår (mill. kr.) & 37.4 & 76.0 & 83.2 & 60.0 \\
\hline 4. Klagebehandling ses som et strategisk redskab & 1.48 & 2.71 & 2.54 & 2.26 \\
\hline 5. Antal år virksomhedsenheden har eksisteret & 33.8 & 25.8 & 71.6 & 32.7 \\
\hline 6. Opfattet kundeutilfredshed & 2.35 & 1.88 & 2.06 & 2.11 \\
\hline $\begin{array}{l}\text { 7. Tillagt betydning af forrentning af klagehåndteringssy- } \\
\text { stem }\end{array}$ & 2.30 & 2.76 & 3.19 & 3.33 \\
\hline $\begin{array}{l}\text { 8. Antal utilfredse/klagende kunder sammenlignet med } \\
\text { branchen som helhed }\end{array}$ & 1.65 & 1.94 & 1.98 & 1.96 \\
\hline
\end{tabular}

Noter:

a $: 5$-punkt-skala, hvor $1=i$ meget lille omfang og $5=i$ meget stort omfang

Tallene i tabellen repræsenterer gennemsnit på den anvendte skala.

Forskellen imellem gruppe 1 og 2 er , for både Danmark og Sverige, signifikant forskellig fra 0

(signifikansniveau 5\%) for karakteristikaene b-h samt for Sverige desuden for karakteristika a.

Gruppe 2 repræsenterer i begge lande virksomheder, som skiller sig ud ved at have en signifikant højere score på de undersøgte aspekter sammenlignet med undersøgelsens øvrige virksomheder (gruppe 1). I Danmark indeholder gruppe 256 virksomheder, mens gruppe 2 i Sverige består af 48 virksomheder.

Gruppe 1 og 2 virksomhederne adskilles kun på et enkelt af de undersøgte virksomheds-karakteristika. I Danmark har gruppe 1 virksomhederne en signifikant lavere tilbøjelighed til at opfatte klagebehandling som et strategisk redskab. 
Virksomhedernes omfang af selvstcendig klagebehandling

I tabel 6.7 er angivet i hvilket omfang virksomhederne foretager selvstændig klagebehandling.

Tabel 6.7 Omfanget af selvstændig klagebehandling i virksomhederne

\begin{tabular}{|c|c|c|c|c|c|c|c|c|c|c|}
\hline \multirow{2}{*}{$\begin{array}{l}\text { Land } \\
\text { Branche }\end{array}$} & \multicolumn{5}{|c|}{ Danmark } & \multicolumn{5}{|c|}{ Sverige } \\
\hline & Møbler & $\begin{array}{r}\text { Daglig- } \\
\text { varer }\end{array}$ & $\begin{array}{l}\text { Elek- } \\
\text { tronik }\end{array}$ & Biler & $\begin{array}{r}\text { Statis- } \\
\text { tiske } \\
\text { for- } \\
\text { skelle* }\end{array}$ & Møbler & $\begin{array}{r}\text { Daglig- } \\
\text { varer }\end{array}$ & $\begin{array}{l}\text { Elek- } \\
\text { tronik }\end{array}$ & Biler & $\begin{array}{r}\text { Statis- } \\
\text { tiske } \\
\text { for- } \\
\text { skelle* }^{*}\end{array}$ \\
\hline & A & $\mathrm{B}$ & $C$ & $\mathrm{D}$ & & A & B & $C$ & $D$ & \\
\hline \multicolumn{11}{|l|}{$\begin{array}{l}\text { Angiv i hvilket } \\
\text { omfang I: }\end{array}$} \\
\hline $\begin{array}{l}\text { a. Videresender } \\
\text { skriftlige klager til } \\
\text { andre led i distributi- } \\
\text { onskæden }\end{array}$ & 3.24 & 3.90 & 2.76 & 2.70 & $B>C, D$ & 3.60 & 3.91 & 3.28 & 3.74 & Ingen \\
\hline $\begin{array}{l}\text { b. Videresender } \\
\text { klageren til andre led } \\
\text { i distributionskæden }\end{array}$ & 3.32 & 3.87 & 2.85 & 2.40 & $B>D$ & 2.30 & 2.97 & 2.89 & 2.55 & Ingen \\
\hline
\end{tabular}

Noter: 5-punkt-skala, hvor 1=i meget lille omfang og $5=i$ meget stort omfang

Tallene $\mathrm{i}$ tabellen repræsenterer gennemsnit på den anvendte skala.

* Signifikansniveau: $5 \%$.

I Sverige er der ingen signifikante forskelle på virksomhederne i forhold til de to undersøgte aspekter. Dog synes det mere udbredt blandt virksomhederne at videresende skriftlige klager til andre led i distributionskæden, end at videresende klageren til andre led i distributionskæden. I Danmark skiller dagligvareforhandlerne sig ud ved i højere end elektronik- og bilforhandlere at videresende skriftlige klager til andre led i distributionskæden. Desuden videresender dagligvareforhandlere mere hyppigt end bilforhandlere klageren til andre led i distributionskæden.

\section{Intern klagekultur $i$ virksomhederne}

Virksomhedernes forhold til klager kan også studeres med udgangspunkt i, hvorledes de behandler ansatte som begår fejl, eller som modtager klager. Resultaterne heraf er vist i tabel 6.8 nedenfor. Af tabellen fremgår, at det $\mathrm{i}$ både danske og svenske virksomheder er udbredt, at den ansatte mister bonus el.lign. (spm. b). En sammenligning af spm. a, b og c viser desuden, at egentlige irettesættelser ikke er ret udbredte i Danmark, men at virksomhederne i stedet mere hyppigt anvender såvel negative (fjernelse af bonus) som positive handlingsincitamenter (belønning hvis der sker forbedring). 
Tabel 6.8 Intern 'klagekultur' virksomhederne

\begin{tabular}{|c|c|c|c|c|c|c|c|c|c|c|}
\hline \multirow{3}{*}{ Branche } & \multicolumn{5}{|c|}{ Danmark } & \multicolumn{5}{|c|}{ Sverige } \\
\hline & Møbler & $\begin{array}{l}\text { Daglig- } \\
\text { varer }\end{array}$ & $\begin{array}{l}\text { Elek- } \\
\text { tronik }\end{array}$ & Biler & $\begin{array}{r}\text { Statis- } \\
\text { tiske } \\
\text { for- } \\
\text { skelle* }^{*}\end{array}$ & Møbler & $\begin{array}{l}\text { Daglig- } \\
\text { varer }\end{array}$ & $\begin{array}{c}\text { Elek- } \\
\text { tronik }\end{array}$ & Biler & $\begin{array}{r}\text { Statis- } \\
\text { tiske } \\
\text { for- } \\
\text { skelle* }\end{array}$ \\
\hline & A & B & C & D & & $A$ & B & $C$ & D & \\
\hline \multicolumn{11}{|l|}{$\begin{array}{l}\text { Hvordan } \\
\text { behandles de } \\
\text { ansatte, hvis } \\
\text { de begår fejl } \\
\text { eller modtager } \\
\text { klager?: }\end{array}$} \\
\hline $\begin{array}{l}\text { a. Irettesættes } \\
\text { og modtager } \\
\text { henstilling }\end{array}$ & 2.94 & 2.52 & 2.24 & 2.27 & Ingen & 3.97 & 4.31 & 4.19 & 3.81 & Ingen \\
\hline $\begin{array}{l}\text { b. Mister bonus } \\
\text { el.lign. }\end{array}$ & 4.18 & 4.71 & 3.58 & 4.00 & Ingen & 4.17 & 4.74 & 4.75 & 4.23 & Ingen \\
\hline $\begin{array}{l}\text { c. Irettesættes } \\
\text { ikke, men } \\
\text { belønnes for at } \\
\text { forbedre sig }\end{array}$ & 3.97 & 4.71 & 3.52 & 4.30 & $B>C$ & 3.97 & 3.97 & 4.58 & 4.10 & Ingen \\
\hline
\end{tabular}

Noter: 5-punkt-skala, hvor $1=i$ meget lille omfang og $5=i$ meget stort omfang.

Tallene i tabellen repræsenterer gennemsnit på den anvendte skala.

* Signifikansniveau: $5 \%$.

\section{Kommunikation/interaktion imellem virksomhed og kunde}

En væsentlig del af kundernes oplevelse af virksomhedens klagehåndtering dannes naturligvis ved den kommunikation, der sker med den pågældende virksomhed. Det er derfor interessant at undersøge, hvilke konkrete tiltag virksomhederne efter egen opfattelse tilbyder kunderne i denne forbindelse. I tabel 6.9 er vist en oversigt over i alt tre delområder: (1) Hvorledes reagerer virksomheden, når den modtager skriftlige klager, (2) såfremt virksomheden udsender bekræftelse på en skriftlig klage, hvilket indhold har da bekræftelsen og (3) hvorledes og i hvilket omfang informeres kunden om klagebehandlingens forløb?

Ad 1: Generelt angiver virksomhederne (i begge lande), at det er temmelig sjældent, at en skriftligt klagende kunde skal have kontakt med mere end én person i virksomheden (spm. a). Det er dog ikke særligt udbredt blandt virksomhederne at udsende en skriftlig bekræftelse på modtagelse af klagen (spm. b). Enkelte forskelle imellem virksomhederne kan findes, men disse er ikke markante.

Ad 2: Virksomhederne mener samstemmende, at der kun sjældent er tale om en 'standardbekræftelse' i tilfælde, hvor der udsendes skriftlig bekræftelse på modtagelse af en skriftlig klage (spm. a). Bekræftelsen omfatter dog kun i sjældne tilfælde en tidsplan eller en redegørelse for proceduren for klagebehandlingen (spm. c og d), om end dette i Danmark sker lidt hyppigere blandt møbelforhandlere end blandt dagligvareforhandlere. Virksomhederne i både Danmark og Sverige vurderer, at bekræftelsen forholdsvis sjældent er baseret på en bagvedliggende politik for klagebehandlingen (spm. f). I Sverige er bilforhandlere lidt mere til- 
Tabel 6.9 Kommunikation/interaktion imellem virksomhed og kunde

\begin{tabular}{|c|c|c|c|c|c|c|c|c|c|c|}
\hline \multirow{3}{*}{ Branche } & \multicolumn{5}{|c|}{ Danmark } & \multicolumn{5}{|c|}{ Sverige } \\
\hline & \multirow{2}{*}{$\begin{array}{l}\text { Møbler } \\
\text { A }\end{array}$} & $\begin{array}{r}\text { Dagligv } \\
\text { arer }\end{array}$ & $\begin{array}{l}\text { Elek- } \\
\text { tronik }\end{array}$ & \multirow[t]{2}{*}{ Biler } & \multirow[t]{2}{*}{$\begin{array}{r}\text { Statis- } \\
\text { tiske } \\
\text { forskelle }\end{array}$} & Møbler & $\begin{array}{r}\text { Dagligv } \\
\text { arer }\end{array}$ & $\begin{array}{l}\text { Elek- } \\
\text { tronik }\end{array}$ & Biler & \multirow[t]{2}{*}{$\begin{array}{r}\text { Statis- } \\
\text { tiske } \\
\text { forskelle* }\end{array}$} \\
\hline & & $\mathrm{B}$ & C & & & A & B & C & D & \\
\hline $\begin{array}{l}\text { I tilfælde hvor kunden } \\
\text { afgiver en skriftlig kla- } \\
\text { ge angiv da hvor ofte: }\end{array}$ & & & & & & & & & & \\
\hline $\begin{array}{l}\text { a. Kunden skal have } \\
\text { kontakt med mere end } \\
\text { én person i virksom- } \\
\text { heden }\end{array}$ & 1.47 & 1.10 & 1.33 & 1.13 & $A>B$ & 1.63 & 1.60 & 1.75 & 2.00 & Ingen \\
\hline $\begin{array}{l}\text { b. Der udsendes skrift- } \\
\text { lig bekræftelse på } \\
\text { modtagelse af klagen }\end{array}$ & 2.21 & 1.42 & 1.79 & 1.93 & $A>B$ & 1.97. & 1.51. & 2.03 & 2.42 & $B<D$ \\
\hline $\begin{array}{l}\text { I tilfælde hvor I ud- } \\
\text { sender skriftlig be- } \\
\text { kræftelse på modta- } \\
\text { gelse af klagen angiv } \\
\text { da hvor ofte }\end{array}$ & & & & & & & & & & \\
\hline $\begin{array}{l}\text { a. Der er tale om en } \\
\text { standardbekræftelse }\end{array}$ & 1.65 & 1.16 & 1.09 & 1.30 & $A>B, C$ & 1.63 & 1.20 & 1.39 & 1.29 & Ingen \\
\hline $\begin{array}{l}\text { b. Bekræftelsen også } \\
\text { omfatter et svar på } \\
\text { klagen }\end{array}$ & 2.74 & 1.90 & 2.15 & 2.30 & $A>B$ & 2.67 & 2.06 & 2.25 & 2.68 & Ingen \\
\hline $\begin{array}{l}\text { c. Bekræftelsen } \\
\text { omfatter en tidsplan } \\
\text { el.lign. for klagebe- } \\
\text { handlingen }\end{array}$ & 2.18 & 1.35 & 1.70 & 1.83 & $A>B$ & 2.43 & 1.46 & 2.00 & 2.32 & $A, D>B$ \\
\hline $\begin{array}{l}\text { d. Bekræftelsen } \\
\text { omfatter en redegø- } \\
\text { relse for proceduren } \\
\text { for klagebehandlingen }\end{array}$ & 1.91 & 1.10 & 1.52 & 1.43 & $A>B$ & 1.97 & 1.54 & 1.78 & 1.90 & Ingen \\
\hline $\begin{array}{l}\text { e. Der først er } \\
\text { reageret med en } \\
\text { telefonisk bekræftelse } \\
\text { på klagen }\end{array}$ & 2.24 & 1.23 & 1.48 & 1.67 & $A>B, C$ & 2.17 & 1.69 & 1.89 & 2.52 & $B<D$ \\
\hline $\begin{array}{l}\text { f. Bekræftelsen er } \\
\text { baseret på en } \\
\text { bagvedliggende politik } \\
\text { for klagebehandlingen }\end{array}$ & 1.85 & 1.26 & 1.55 & 1.73 & Ingen & 2.37 & 1.63 & 1.78 & 2.52 & $\begin{array}{r}A>B ; \\
D>B, C\end{array}$ \\
\hline $\begin{array}{l}\text { Angiv hvor ofte } \\
\text { følgende hændelser } \\
\text { generelt er forekom- } \\
\text { mende i virks. } \\
\text { klagebehandling: }\end{array}$ & & & & & & & & & & \\
\hline $\begin{array}{l}\text { a. Hvis klagebehand- } \\
\text { lingen tager tid holdes } \\
\text { kunden regelmæssigt } \\
\text { orienteret om } \\
\text { udviklingen }\end{array}$ & 3.32 & 2.42 & 3.30 & 3.23 & $A, C, D>B$ & 3.20 & 2.94 & 3.19 & 3.65 & $B<D$ \\
\hline $\begin{array}{l}\text { b. Der følges telefo- } \\
\text { nisk op på, om kunden } \\
\text { har været tilfreds med } \\
\text { klagebehandlingen }\end{array}$ & 2.09 & 1.81 & 2.15 & 2.27 & Ingen & 2.03 & 1.91 & 2.11 & 3.10 & $A, B, C<D$ \\
\hline $\begin{array}{l}\text { c. Der følges skriftligt } \\
\text { op på, om kunden har } \\
\text { været tilfreds med } \\
\text { klagebehandlingen }\end{array}$ & 1.35 & 1.23 & 1.30 & 1.83 & $D>A, B, C$ & 1.17 & 1.37 & 1.44 & 1.52 & Ingen \\
\hline $\begin{array}{l}\text { d. ommunikationen til } \\
\text { kunden baserer sig på } \\
\text { standardinformation }\end{array}$ & 1.44 & 1.10 & 1.21 & 1.07 & $A>B, D$ & 1.60 & 1.57 & 1.53 & 1.68 & Ingen \\
\hline
\end{tabular}

Noter: 5 -punkt-skala, hvor $1=$ meget sjældent og $5=$ meget ofte.

Tallene i tabellen repræsenterer gennemsnit på den anvendte skala.

* Signifikansniveau: $5 \%$. 
bøjelig til at have en bagvedliggende politik for klagebehandlingen - men stadig er der dog tale om gennemsnit under midten på den anvendte skala.

Ad 3 Virksomhederne - i begge lande - angiver, at det kun er forholdsvis sjældent, at kommunikationen til kunden baserer sig på standardinformation (spm. d), dvs., at informationen i overvejende grad tilpasses den specifikke problemstilling/kunde. I Danmark anvendes standardinformation lidt mere hyppigt blandt møbelforhandlere end blandt dagligvare- og bilforhandlere, men stadig er der tale om en begrænset anvendelse.

Virksomhederne vurderer også, at der kun i begrænset omfang følges telefonisk (spm. b) eller skriftligt (spm. c) op på, om kunden har været tilfreds med klagebehandlingen. I Danmark er bilforhandlere lidt mere tilbøjelige til at følge skriftligt op på kundens tilfredshed med klagebehandlingen, mens bilforhandlere i Sverige er lidt mere tilbøjelige til at følge telefonisk op sammenlignet med de øvrige virksomhedstyper. Virksomhederne er derimod - i begge lande - mere tilbøjelige til regelmæssigt at holde kunden orienteret om udviklingen i klagebehandlingen (spm. a). I Danmark holder dagligvareforhandlere mindst hyppigt kunden orienteret om klagebehandlingen, og i Sverige er dagligforhandlere mindre tilbøjelige end bilforhandlere til at holde kunden orienteret.

\section{Årsager til indførelse af klagehåndteringsprocedurer}

I tilfælde, hvor virksomhederne reagerer med en telefonisk bekræftelse på modtagelse af klager, synes årsagen blandt de svenske virksomheder især at være at give virksomheden et menneskeligt ansigt udadtil (tabel 6.10, spm. a). I Danmark er det især møbelforhandlere, som angiver dette som årsag til telefonisk opfølgning. Derimod er det ikke så udpræget blandt virksomhederne at anvende den telefoniske opfølgning med henblik på at søge at spare ressourcer ved at undlade en skriftlig bekræftelse (spm. b). Dog skiller svenske dagligvareforhandlere sig her lidt ud ved i videre omfang end møbel- og bilforhandlere at søge at spare ressourcer ved at undlade skriftlig bekræftelse.

I tabel 6.10 fremgår desuden virksomhedernes vurderinger af, hvilken betydning klagehåndtering har for forskellige forhold af betydning for virksomhedernes konkurrencemæssige stilling, kvalitetsudvikling mv. Samtlige svenske virksomheder ligger her over midten på den anvendte skala for følgende forhold: at opnå konkurrencemæssige fordele (spm b.), at kunne kvalitetsudvikle virksomhedens produkter (spm.c) og at kunne kvalitetsudvikle kundeinformation (spm. d). Navnlig svenske bilforhandlere mener, at klagehåndtering har betydning for opnåelse af konkurrencemæssige fordele og for at kunne kvalitetsudvikle virksomhedens kundeinformation. Danske virksomheder ligger gennemgående noget lavere på den anvendte skala $\mathrm{i}$ forhold til vurderingen af klagehåndteringens betydning for disse forhold. Møbelforhandlerne skiller sig dog her lidt ud 
ved generelt at anse klagehåndtering som lidt mere betydende for de undersøgte forhold sammenlignet med de øvrige virksomheder.

Virksomhederne er samlet set kun i relativt begrænset omfang optagede af at undgå omkostninger ved tvister/retssager via klagehåndtering (spm. a). Undtaget herfra er dog de svenske bilforhandlere samt i lidt mindre omfang danske møbelforhandlere.

Tabel 6.10 Ârsager til indførelse af klagehåndteringsprocedurer

\begin{tabular}{|c|c|c|c|c|c|c|c|c|c|c|}
\hline \multirow{3}{*}{ Branche } & \multicolumn{5}{|c|}{ Danmark } & \multicolumn{5}{|c|}{ Sverige } \\
\hline & Møbler & $\begin{array}{l}\text { Dag- } \\
\text { ligva- } \\
\text { rer }\end{array}$ & $\begin{array}{c}\text { Elek- } \\
\text { tronik }\end{array}$ & Biler & $\begin{array}{r}\text { Statis- } \\
\text { tiske- } \\
\text { forskel- } \\
l e^{*}\end{array}$ & Møbler & $\begin{array}{l}\text { Dag- } \\
\text { ligva- } \\
\text { rer }\end{array}$ & $\begin{array}{l}\text { Elek- } \\
\text { tronik }\end{array}$ & Biler & $\begin{array}{l}\text { Statis- } \\
\text { tiskefo } \\
\text { rskelle* }^{*}\end{array}$ \\
\hline & $\mathrm{A}$ & $B$ & $C$ & $D$ & & A & $B$ & $\mathrm{C}$ & D & \\
\hline \multicolumn{11}{|l|}{$\begin{array}{l}\text { Hvis der reage- } \\
\text { res med en } \\
\text { telefonisk } \\
\text { bekræftelse på } \\
\text { modtagelsen af } \\
\text { klagen, angiv da } \\
\text { i hvilket omfang } \\
\text { følgende } \\
\text { aspekter ligger til } \\
\text { grund herfora: }\end{array}$} \\
\hline $\begin{array}{l}\text { a. At give } \\
\text { virksomheden et } \\
\text { menneskeligt } \\
\text { ansigt udadtil }\end{array}$ & 4.03 & 2.35 & 3.12 & 2.83 & $A>B, D$ & 4.03 & 4.43 & 4.14 & 3.97 & Ingen \\
\hline $\begin{array}{l}\text { b. At spare } \\
\text { ressourcer ved } \\
\text { at undlade } \\
\text { skriftlig bekræf- } \\
\text { telse }\end{array}$ & 2.91 & 2.26 . & 2.45 & 2.20. & Ingen & 2.60 & 3.69 & 3.08 & 2.71 & $B>A, D$ \\
\hline \multicolumn{11}{|l|}{$\begin{array}{l}\text { Giv en } \\
\text { forretnings- } \\
\text { mæssig } \\
\text { vurdering af } \\
\text { hvilken betyd- } \\
\text { ning klagehånd- } \\
\text { tering har for } \\
\text { følgende forhold }\end{array}$} \\
\hline $\begin{array}{l}\text { h: At undgå } \\
\text { omkostninger } \\
\text { ved tvi- } \\
\text { ster/retssager }\end{array}$ & 3.00 & 2.45 & 2.00 & 2.23 & $A>C, D$ & 2.17 & 2.26 & 2.58 & 3.58 & $\begin{array}{r}D>A, B \\
C\end{array}$ \\
\hline $\begin{array}{l}\text { b. At opnå } \\
\text { konkurrence- } \\
\text { mæssige fordele }\end{array}$ & 3.24 & 2.23 & 2.61 & 2.90 & $A>B$ & 3.13 & 3.20 & 3.17 & 4.19 & $\begin{array}{r}D>A, B \\
C\end{array}$ \\
\hline $\begin{array}{l}\text { c. At kunne } \\
\text { kvalitetsudvikle } \\
\text { virks. produkter }\end{array}$ & 3.18 & 2.10 & 2.30 & 2.77 & $\begin{array}{r}A>B, C \\
B<D\end{array}$ & 3.37 & 3.37 & 3.47 & 3.97 & Ingen \\
\hline $\begin{array}{l}\text { d. At kunne } \\
\text { kvalitetsudvikle } \\
\text { virks. kundein- } \\
\text { formation }\end{array}$ & 3.09 & 1.68 & 2.39 & 2.50 & $\begin{array}{l}A>B, C \\
B<C, D\end{array}$ & 3.37 & 3.14 & 3.31 & 3.90 & $B<D$ \\
\hline
\end{tabular}

Noter:

a 5 -punkt-skala, hvor $1=$ meget sjældent og $5=$ meget ofte.

b: 5 -punkt-skala, hvor $1=$ =meget lille betydning og $5=$ meget stor betydning.

Tallene i tabellen repræsenterer gennemsnit på den anvendte skala.

* Signifikansniveau: $5 \%$. 



\section{Virksomhedernes forhold til lovgivning, ankenævn mv.}

I tabel 7.1 er opgjort virksomhedernes svar på en række spørgsmål, som er relaterede til virksomhedernes forhold til lovgivning og ankenævn/reklamationsnævn.

Virksomhederne mener - $\mathrm{i}$ begge lande og uanset branche - at de $\mathrm{i}$ betydeligt omfang efterlever de branchespecifikke regler, som måtte gælde for klagehåndtering $(\mathrm{spm}$. c). Derimod vejleder virksomhederne kun i ringe omfang kunderne om ankemuligheder (spm. a), ligesom også virksomhedernes personale kun i begrænset omfang bliver instrueret i klagerelateret lovgivning (spm. b). Navnlig de svenske bilforhandlere adskiller sig dog positivt på spørgsmål a.

Virksomhedernes klagehåndtering er ikke i udpræget grad præget af afgørelser truffet i ankenævn (DK) / reklamationsnævn (S) (spm. d). Tilsvarende tillægger virksomhederne kun ankenævn/reklamationsnævn en ringe betydning for virksomhedens kompetenceudvikling vedrørende klagebehandling og kvalitetsudvikling (spm. e).

Imidlertid mener virksomhederne dog generelt, at deres klagehåndtering stiller kunden lidt bedre, eller noget bedre, i forhold til de retningslinier, som følger af love eller retspraksis (spm. f). I Danmark er navnlig dagligvareforhandlerne tilbøjelige til at mene dette, mens der i Sverige ikke er forskelle imellem de enkelte brancher på dette spørgsmål.

I Danmark er møbelforhandlerne klart overrepræsenterede, hvad angår andelen af kundeklager, som ender ved enten ankenævn (62\%) eller domstol (32\%) (spm. g og h). I Sverige er bilforhandlerne overrepræsenterede I forhold til andelen af kundeklager, som ender ved reklamationsnævn (62\%). Disse procenttal er lidt voldsomme og stemmer næppe overens med de faktiske forhold. Det må formodes, at virksomhederne ikke har opfattet spørgsmålene $\mathrm{g}$ og h som tiltænkt, hvorfor procenttallene ikke bør tillægges betydning.

\section{Virksomhedsprofiler}

Med udgangspunkt i indholdet af virksomhedernes forhold til ankenævn mv. er virksomhederne i både Danmark og Sverige nedenfor opdelt $i$ to grupper $^{25}$ (tabel 7.2). I Danmark skiller 33 virksomheder (gruppe 2) sig ud ved gennemsnitligt at have en signifikant højere score på de fire undersøgte aspekter (spm. a-d) sammenlignet med undersøgelsens øvrige 95 virksomheder (gruppe 1). I Sverige skiller hele 91 virksomheder (gruppe

${ }^{25}$ Ved hjælp af klyngeanalyse. 
2) sig ud ved gennemsnitligt at have en signifikant højere score på de fire undersøgte aspekter sammenlignet med undersøgelsens øvrige 41 virksomheder (gruppe 1).

\section{Tabel 7.1 Virksomhedernes forhold til lovgivning, ankenævn mv.}

\begin{tabular}{|c|c|c|c|c|c|c|c|c|c|c|}
\hline \multirow{3}{*}{ Branche } & \multicolumn{5}{|c|}{ Danmark } & \multicolumn{5}{|c|}{ Sverige } \\
\hline & Møbler & $\begin{array}{r}\text { Dagligv } \\
\text { arer }\end{array}$ & $\begin{array}{l}\text { Elek- } \\
\text { tronik }\end{array}$ & Biler & $\begin{array}{r}\text { Statis- } \\
\text { tiske } \\
\text { for- } \\
\text { skelle }^{*}\end{array}$ & Møbler & $\begin{array}{l}\text { Daglig- } \\
\text { varer }\end{array}$ & $\begin{array}{l}\text { Elek- } \\
\text { tronik }\end{array}$ & Biler & $\begin{array}{r}\text { Statis- } \\
\text { tiske } \\
\text { for- } \\
\text { skelle* }\end{array}$ \\
\hline & $A$ & B & C & $D$ & & A & B & C & $\mathrm{D}$ & \\
\hline $\begin{array}{l}\text { Angiv, i hvilket omfang } \\
\text { I tillægger følgende } \\
\text { aspekter betydning i } \\
\text { virksomhedens } \\
\text { klagehåndteringa: }\end{array}$ & & & & & & & & & & \\
\hline $\begin{array}{l}\text { a. Virks. vejleder } \\
\text { kunden om muligheder } \\
\text { for sagsanlæg, } \\
\text { ankemuligheder mv. }\end{array}$ & 1.59 & 1.00 & 1.39 & 1.53 & $B<A, D$ & 1.77 & 1.37 & 2.14 & 2.42 & $\begin{array}{r}A, B<D ; \\
B<C\end{array}$ \\
\hline $\begin{array}{l}\text { b. Virks. personale } \\
\text { bliver instrueret i } \\
\text { klagerelateret } \\
\text { lovgivning }\end{array}$ & 2.12 & 1.03 & 1.94 & 1.43 & $\begin{array}{r}A>B, D ; \\
B<C\end{array}$ & 2.03 & 1.37 & 2.06 & 2.26 & $\begin{array}{r}A, C, D> \\
B\end{array}$ \\
\hline $\begin{array}{l}\text { c. Virks. følger evt. } \\
\text { branchespecifikke } \\
\text { regler for klagehåndte- } \\
\text { ring }\end{array}$ & 4.21 & 3.71 & 3.58 & 3.53 & Ingen & 4.57 & 4.26 & 4.42 & 4.32 & Ingen \\
\hline $\begin{array}{l}\text { d. Virks. klagehåndte- } \\
\text { ring er påvirket af } \\
\text { afgørelser truffet i } \\
\text { ankenævn } \\
\text { (DK)/reklamations- } \\
\text { nævn (Sv) } \\
\text { Vurder hvilken } \\
\text { betydning b: }\end{array}$ & -2.85 & $-\underline{2} \cdot \underline{19}$ & -1.85 & 2.00 & $\underline{A} \leq \mathbf{C}$. & -2.53 & 1.86 & 2.92 & 3.48 & $\begin{array}{r}A<D ; \\
B<C, D\end{array}$ \\
\hline $\begin{array}{l}\text { e. nkenævnet(DK)/re- } \\
\text { klamationsnævnet } \\
\text { (Sv.) har betydning for } \\
\text { jeres kompetenceud- } \\
\text { vikling vedrørende } \\
\text { klagebehandling og } \\
\text { kvalitetsudvikling } \\
\text { Hvordan mener l, at: c: }\end{array}$ & -1.81 & -1.50 & -1.23 & 1.67 & $\underline{A} \geq \underline{C}$ & -2.30 & 1.31 & -2.11 & 2.29 & $\begin{array}{r}A, C, D> \\
-\end{array}$ \\
\hline $\begin{array}{l}\text { f. Jeres klagehåndte- } \\
\text { ring stiller kunden i } \\
\text { forhold til de retnings- } \\
\text { linier, der følger af love } \\
\text { eller retspraksis? } \\
\text { Angiv i procent }\end{array}$ & -2.67 & 1.46 & -1.94 & 2.07 & $\begin{array}{l}A>B, C, \\
D\end{array}$ & 3.00 & 2.64 & 2.85 & 2.71 & Ingen \\
\hline $\begin{array}{l}\text { g. Cirka hvor stor en } \\
\text { andel, hvor jeres } \\
\text { kunder klager, der } \\
\text { ender ved en domstol }\end{array}$ & $32 \%$ & $3 \%$ & $12 \%$ & $20 \%$ & $A>B, C$ & $0 \%$ & $3 \%$ & $14 \%$ & $10 \%$ & $A<C$ \\
\hline $\begin{array}{l}\text { h. Hvor stor en andel, } \\
\text { hvor jeres kunder } \\
\text { klager, der ender ved } \\
\text { ankenævn/rekla- } \\
\text { mationsnævn }\end{array}$ & $62 \%$ & $8 \%$ & $29 \%$ & $27 \%$ & $\begin{array}{r}A>B, C \\
D\end{array}$ & $13 \%$ & $29 \%$ & $44 \%$ & $65 \%$ & Ingen \\
\hline
\end{tabular}

Noter: ${ }^{a} 5$-punkt-skala, hvor $1=i$ meget lille omfang og $5=i$ meget stort omfang.

b 5 -punkt-skala, hvor $1=$ =meget lille betydning og $5=$ =meget stor betydning

${ }^{c} 5$-punkt-skala, hvor $1=$ =samme niveau; $2=$ lidt bedre; $3=$ noget bedre og $4=$ =meget bedre.

Tallene i tabellen repræsenterer gennemsnit på den anvendte skala. Signifikansniveau: $5 \%$. 
Danske gruppe 2 virksomheder har en signifikant større tilbøjelighed til at anse klagebehandling som et strategisk redskab og oplever desuden, at de har færre utilfredse/klagende kunder sammenlignet med den pågældende branche som helhed. Svenske gruppe 2 virksomheder tillægger forretningen af klagehåndteringssystemet en signifikant højere betydning end gruppe 1 virksomhederne. I ingen af landende kunne der påvises nogen forskelle imellem gruppe 1 og 2 hvad angår økonomiske mål såsom omsætning og overskudsgrad.

Tabel 7.2 Profilering af virksomheder med hensyn til forhold til ankenævn mv.

\begin{tabular}{|c|c|c|c|c|}
\hline \multirow[b]{2}{*}{ Gruppe } & \multicolumn{2}{|c|}{ Danmark } & \multicolumn{2}{|c|}{ Sverige } \\
\hline & Gruppe $1 \mathrm{n}=95$ & Gruppe $2 n=33$ & Gruppe $1 \mathrm{n}=41$ & Gruppe $2 n=91$ \\
\hline \multicolumn{5}{|l|}{$\begin{array}{l}\text { Angiv, i hvilket omfang I tillægger følgende aspekter } \\
\text { betydning i virksomhedens klagehåndteringa: }\end{array}$} \\
\hline $\begin{array}{l}\text { a. Virks. vejleder kunden om muligheder for sagsanlæg, } \\
\text { ankemuligheder mv. }\end{array}$ & 1.28 & 1.67 & 1.20 & 2.24 \\
\hline $\begin{array}{l}\text { b. Virks. personale bliver instrueret i klagerelateret } \\
\text { lovgivning }\end{array}$ & 1.47 & 2.15 & 1.34 & 2.18 \\
\hline $\begin{array}{l}\text { c. Virks. følger evt. branchespecifikke regler for klage- } \\
\text { håndtering }\end{array}$ & 3.36 & 4.94 & 2.95 & 5.03 \\
\hline $\begin{array}{l}\text { d. Virks. klagehåndtering er påvirket af afgørelser truffet i } \\
\text { ankenævn (DK)/reklamations-nævn (Sv) }\end{array}$ & 1.26 & 5.03 & 1.54 & 3.20 \\
\hline \multicolumn{5}{|l|}{$\begin{array}{l}\text { Karakteristika for virksomhedsgrupperinger } \\
\text { (statistiske forskelle fremhævet med fed-kursiv) }\end{array}$} \\
\hline 1. Antal ansatte & 23.31 & 11.91 & 24.46 & 28.01 \\
\hline 2. Overskudsgrad & 7.88 & 13.21 & 6.15 & 6.91 \\
\hline 3. Omsætning i seneste regnskabsår (mill. kr.) & 41.3 & 27.1 & 66.6 & 58.2 \\
\hline 4. Klagebehandling ses som et strategisk redskab & 1.64 & 2.42 & 2.29 & 2.62 \\
\hline 5. Antal år virksomhedsenheden har eksisteret & 35.11 & 30.61 & 27.22 & 52.08 \\
\hline 6. Opfattet kundeutilfredshed & 1.57 & 1.46 & 1.89 & 1.81 \\
\hline $\begin{array}{l}\text { 7. Tillagt betydning af forrentning af klagehåndteringssy- } \\
\text { stem }\end{array}$ & 1.27 & 1.53 & 2.51 & 3.07 \\
\hline $\begin{array}{l}\text { 8. Antal utilfredse/klagende kunder sammenlignet med } \\
\text { branchen som helhed }\end{array}$ & 1.96 & 1.58 & 1.93 & 1.86 \\
\hline
\end{tabular}

Noter:

a : 5-punkt-skala, hvor 1=i meget lille omfang og 5=i meget stort omfang.

Tallene i tabellen repræsenterer gennemsnit på den anvendte skala.

Forskellen imellem gruppe 1 og 2 er , for både Danmark og Sverige, signifikant forskellig fra 0 (signifikansniveau $5 \%$ ) for karakteristikaene a-d. 



\section{Resumé og anbefalinger}

\subsection{Resumé}

I dette afsnit sammenfattes de resultater, som er fremkommet i afsnittene 4-7. Det nærværende afsnit er opbygget, så det i hovedtræk følger strukturen for afrapporteringen af resultaterne.

Blandt de undersøgte virksomheder opfattes klagebehandling kun i begrænset omfang som et strategisk værktøj, ligesom det ikke er udbredt, at virksomhedernes klagebehandling er baseret på skriftligt formulerede politikker, som specificerer procedurer mv. for klagebehandlingen. Til trods for dette udgør klagebehandling et emne, som topledelserne i et middelstort omfang engagerer sig i dagligt.

Virksomhederne er ikke afvisende overfor, at klagende kunder besidder vigtig information, og at klagehåndteringsprocedurer desuden vil kunne give virksomheden et menneskeligt ansigt udadtil. Særligt virksomheder, som har implementeret klagebehandlingsprocedurer, lægger vægt på at investering i klagebehandlingssystemer kan forrente sig.

Man må også konstatere, at virksomhederne afgiver tilsyneladende modstridende oplysninger med hensyn til, hvor stor en del af deres kunder der er utilfredse, og med hensyn til i hvilket omfang deres kunder giver udtryk for deres utilfredshed ved at klage. Således mener virksomhederne gennemsnitligt, at de både har færre utilfredse og færre klagende kunder sammenlignet med de respektive brancher som helhed. De undervurderer altså enten antallet af deres egne utilfredse/klagende kunder, eller også overvurderer de antallet af utilfredse/klagende kunder hos andre virksomheder.

Det er også interessant, at topledelsen er mest tilbøjelig til at engagere sig i den daglige klagebehandling i de virksomheder, hvor klagebehandling ses som et strategisk redskab, og hvor der er etableret politikker, som specificerer klagebehandlingsprocedurer mv. En forklaring kan ligge i, at klagebehandling i disse virksomheder udgør et samlet indsatsområde for virksomheden. Således har virksomheder med et strategisk syn på klagebehandling i større omfang etableret forskellige klagehåndteringstiltag end virksomheder, som kun i mindre omfang opfatter klagebehandling som et strategisk redskab. Undersøgelsen viser dog også, at virksomhederne (set under ét) kun i ringe omfang har allokeret ressourcer til klagehåndteringsaktiviteter, og at de desuden kun i ringe omfang fokuserer på interpersonelle kompetencer, når de rekrutterer nyt personale.

Virksomheder, som opfatter klagebehandling som et strategisk værktøj, og som eksplicit har specificeret procedurer mv. for klagebehandling, har ikke en bedre driftsmæssig stilling (målt på overskudsgrad) sammen- 
lignet med virksomheder, som kun i begrænset omfang har denne opfattelse af klagebehandling.

\section{Strategisk og politisk syn på klagebehandling}

- Det er ikke udbredt blandt virksomhederne at betragte klagebehandling som et strategisk værktøj, ligesom det heller ikke er udbredt at have skriftligt formulerede politikker, som specificerer procedurer mv. for klagebehandling. Dette gælder i begge lande og i alle undersøgte brancher.

- Topledelsen engagerer sig i middel omfang i virksomhedernes daglige klagebehandling. Dette engagement hviler kun i begrænset omfang på et strukturelt grundlag - og man må derfor formode, at der er tale om daglige ad hoc indgreb.

- Virksomhederne tillægger det gennemsnitligt en middel betydning, at investering i klagebehandling kan forrente sig. Brancher, som gennemgående har formuleret skriftlige politikker for klagebehandling, eller hvor topledelsen mest hyppigt er involveret $\mathrm{i}$ klagebehandlingen, tillægger forrentningen af investeringen i klagebehandling størst betydning.

- Virksomheder, som har et struktureret (strategisk og politisk) syn på klagebehandling, er gennemgående større (omsætning og/eller antal ansatte) end virksomheder med et mindre struktureret syn.

- Danske virksomheder, som har et struktureret (strategisk og politisk) syn på klagebehandling, oplever en større kundeutilfredshed, end virksomheder med et mindre struktureret syn.

\section{Virksomhedernes omfang af utilfredse kunder}

- Det gennemsnitlige billede af virksomhedernes vurderinger er, at kun ganske få (mindre end 2\%) kunder har været utilfredse med virksomhedens produkter/ydelser, har været utilfredse med virksomhedens informationsafgivning/rådgivning eller har været utilfredse med virksomheden af anden årsag. Der er kun ganske små brancheforskelle for disse tre aspekter af utilfredshed.

- I alle brancher - $\mathrm{i}$ begge lande - har en større andel af kunder ytret tilfredshed med de undersøgte virksomheder sammenlignet med den andel, som har ytret utilfredshed.

- Virksomhederne (i begge lande) mener gennemsnitligt, at de har færre utilfredse kunder sammenlignet med branchen som helhed og ligeledes, at de har færre klagende kunder sammenlignet med branchen som helhed.

- Såfremt det antages, at de undersøgte virksomheder for de enkelte brancher repræsenterer et retvisende billede af populationen af virksomheder, tyder resultatet på, at virksomhederne enten overvurderer antallet af utilfredse/klagende kunder i de enkelte brancher og/eller 
undervurderer virksomhedens eget omfang af utilfredse/klagende kunder.

\section{Virksomhedernes syn på klagende kunder}

- I gennemsnit mener samtlige virksomheder, i begge lande, kun i begrænset omfang, at klagende kunder er besværlige kunder, at klagende kunder er en økonomisk omkostning, at klagende kunder er ødelæggende for arbejdsmiljøet, og at klagende kunder er psykisk belastende.

- Virksomhederne mener i middel omfang, at klagende kunder besidder vigtig information.

- Virksomhederne er i begge lande forholdsvis enige om, at klager kun i begrænset omfang skyldes, at virksomhederne havde givet kunden mangelfuld eller forkert information, at kunden havde urealistiske forventninger til informationer fra virksomhedernes side, eller at kunden havde urealistiske forventninger til virksomhedens produkt.

- I begge lande vurderer møbelforhandlere, at kundeklager navnlig skyldes, at produktet var fejlbehæftet.

\section{Virksomhedernes syn på konsekvenser af kundeutilfredshed}

- Virksomhederne er gennemgående enige om, at utilfredse kunder i middel, eller større, omfang vil kunne resultere $i$, at den enkelte virksomhed får et dårligt omdømme. I Danmark anlægger navnlig bilforhandlere en sådan vurdering, mens der ingen statistiske forskelle findes blandt de svenske virksomheder for dette spørgsmål.

- Både danske og svenske virksomheder er i middel omfang bekymrede for, at utilfredse kunder kan føre til tab af markedsandel. Også her er danske bilforhandlere de mest bekymrede, mens der ikke kan påvises nogle forskelle imellem de svenske virksomheder.

- I jo højere grad virksomhederne oplever kundeutilfredshed i jo højere grad opfatter virksomhederne negative konsekvenser af kundeutilfredshed.

\section{Klageopfordringstiltag $i$ virksomhederne}

- I Sverige er udbredelsen af klageopfordringstiltag noget større end i Danmark.

- I Danmark skiller møbelbranchen sig ud ved at anvende hovedparten af klageopfordringstiltagene i større omfang end de øvrige brancher.

- Dansk og svenske virksomheder tillægger gennemgående anvendelsen af klageopfordringstiltag ringe betydning i klagehåndteringen.

- I jo højere grad danske virksomheder anser klageopfordringstiltag som betydningsfulde i jo højere grad vil danske virksomheder - set under ét - være tilbøjelige til at iværksætte sådanne tiltag. Denne sammenhæng kunne ikke påvises for de svenske virksomheder i undersøgelsen. 


\section{Interaktionen imellem virksomhed og kunde}

- Virksomhederne mener samstemmende, at der kun sjældent er tale om en 'standardbekræftelse' i tilfælde, hvor der udsendes skriftlig bekræftelse på modtagelse af en skriftlig klage. Bekræftelsen omfatter dog kun i sjældne tilfælde en tidsplan eller en redegørelse for proceduren for klagebehandlingen.

- Der følges kun i begrænset omfang op på (telefonisk eller skriftligt), om kunden har været tilfreds med klagebehandlingen.

- Jo flere utilfredse kunder virksomhederne oplever, jo mere tilbøjelige er de til at opfatte klagende kunder negativt (dvs. som besværlige, som en økonomisk og psykisk omkostning mv.).

\section{Indholdet $i$ virksomhedernes klagebehandling}

- Det generelle billede er, at virksomhederne kun i begrænset omfang har iværksat systematiserede klagehåndteringstiltag (herunder bl.a. intern personaleuddannelse i klagehåndtering, eksterne kurser for personale i klagehåndtering, central samling og overvågning af klageinformation, anvendelse af fastlagte politikker for klagebehandling og opsætning af klare specifikationer for klageregistrering).

- I Sverige har bilforhandlerne en tendens til at have en højere udbredelse af klagehåndteringstiltag end de øvrige brancher.

- Virksomheder, som har iværksat klagehåndteringstiltag, er gennemgående større (omsætning og/eller antal ansatte) end virksomheder, som kun i mindre omfang har iværksat sådanne tiltag.

\section{Resultat af virksomhedernes klagebehandling}

- Ifølge virksomhederne afvises kun få klagende kunder, hvad enten afvisningen foretages uden begrundelse eller med skriftlig eller mundtlig begrundelse.

- Klagende kunder gives ifølge virksomhederne lidt oftere ubetinget eller delvist medhold.

- Nogle typer af klagekompensation benyttes i vidt omfang af virksomhederne (f.eks. gratis reparation eller bytning af produktet), mens andre kun benyttes i mere begrænset omfang (f.eks. aflevering af symbolsk gave til kunden eller overkompensation).

- Det er i både Danmark og Sverige udbredt blandt de undersøgte virksomheder at yde kunderne kompensation for det kunden skulle have modtaget.

- I jo højere grad virksomhederne yder kunderne klagekompensation jo højere kundetilfredshed oplever virksomhederne i både Danmark og Sverige. 


\section{Virksomhedernes interne klagekultur}

- Det er udbredt i virksomhederne i både Danmark og Sverige, at de ansatte - hvis de begår fejl - mister bonus el. lign, eller at de gives en belønning ved forbedring.

- Egentlige irettesættelser i tilfælde af begående fejl er mere udbredte i Sverige end i Danmark.

Virksomhedernes forhold til lovgivning og anke-/reklamationsnavn

- Virksomhedernes klagehåndtering er ikke i udpræget grad præget af afgørelser truffet i ankenævn (DK) / reklamationsnævn (S).

- Virksomhederne tillægger kun ankenævn/reklamationsnævn en ringe betydning for virksomhedens kompetenceudvikling vedrørende klagebehandling og kvalitetsudvikling.

- Virksomhederne mener generelt, at deres klagehåndtering stiller kunden lidt bedre, eller noget bedre, i forhold til de retningslinier, som følger af love eller retspraksis. I Danmark er navnlig dagligvareforhandlerne tilbøjelige til at mene dette, mens der i Sverige ikke er forskelle imellem de enkelte brancher på dette spørgsmål.

\subsection{Anbefalinger}

De følgende anbefalinger er dels udarbejdet på baggrund af de opnåede resultater i denne rapport og dels på baggrund af resultater og indsigt opnået $\mathrm{i}$ øvrig litteratur (hvoraf en væsentlig del er omtalt i rapportens kapitel 2).

- Generelt synes virksomhederne ikke at have større erfaringer med klagebehandlingssystemer, og der er desuden kun gennemført sparsom forskning vedrørende forrentningen af investeringer i sådanne. En undersøgelse viser dog, at man blandt andet i bankbranchen har opnået pæne forrentninger af klagebehandlingssystemer, og at konkurrenceforhold desuden spiller en rolle ${ }^{26}$. For at få afklaret, om investering i klagebehandling har en betydning for virksomhedens konkurrencemæssige stilling, og dermed i sidste ende for virksomhedens lønsomhed, kan der gennemføres en undersøgelse af de fire branchers forbrugere. Undersøgelsen kan bl.a. afdække, hvorledes og i hvilket omfang kundernes oplevelser af klagebehandlingen i virksomheder måtte have betydning for kundernes tilfredshed, beslutninger om genkøb samt udvikling af eventuel kundeloyalitet.

- Resultaterne i denne rapport vedrørende bl.a. kundeutilfredshed bygger på virksomhedernes egne opfattelser heraf. Det vil i denne forbindelse være interessant at se nærmere på (a) om der et gab imellem

${ }^{26}$ Fornell, Claes; Wernerfelt, Birger (1988), A Model for Customer Complaint Management, Marketing Science. 
kundernes egne tilfredshedsoplevelser og virksomhedernes angivelser af kundetilfredshed og (b) om der er en sammenhæng imellem den kundeoplevede tilfredshed og virksomhedernes f.eks. overordnede opfattelse af klagende kunder, klageopfordringstiltag, syn på klagende kunder mv.

- Virksomhederne er gennemgående enige om, at utilfredse kunder i middel eller større omfang vil kunne resultere $i$, at den enkelte virksomhed får et dårligt omdømme og/eller mister markedsandele. Desuden peger rapportens resultater på, at i jo højere grad virksomhederne yder kunderne klagekompensation jo højere kundetilfredshed opleves af virksomhederne. Disse erkendelser vil kunne anvendes af de nordiske landes forbrugermyndigheder ved udarbejdelse af informationsmateriale, dialogmøder, workshops eller andre tiltag med henblik på at forbedre virksomhedernes syn på klagende kunder, anvendelse af klageopfordringstiltag og klagekompensation mv. Her igennem vil kunne skabes grobund for en forbedret kommunikation imellem markedernes efterspørgselsside (forbrugerne) og udbudsside (virksomhederne). En sådan forbedret kommunikation vil være gavnlig for markedsprocessen og dermed også have en vis gavnlig effekt for samfundet som helhed.

- De nordiske landes forbrugermyndigheder kunne søge at identificere et antal 'best practice' virksomheder som dels i betydelig grad har indført klagebehandlingssystemer og som desuden har gode erfaringer hermed. Sådanne 'best practice' virksomheder vil både kunne tjene som inspiration, og som isbryder i forhold til virksomheder som i mindre omfang benytter systematiseret klagebehandling. Dette arbejde vil desuden kunne give mulighed for udarbejdelse af vejledninger om klagebehandling indeholdende praktisk inspiration og erfaringer til supplering af allerede eksisterende vejledninger, herunder navnlig vejledningen udarbejdet af Dansk Standard samt ISO-vejledningen 10002:2004 ${ }^{27}$.

- Virksomhedernes klagehåndtering er kun i begrænset omfang præget af afgørelser truffet i ankenævn/reklamationsnævn. De nordiske landes forbrugermyndigheder kunne i denne forbindelse understrege ankenævnenes/reklamationsnævnenes betydning som hjælpefunktioner i forhold til, hvorledes virksomhedernes mest gunstigt indretter sig på markedet med henblik på at opnå en gavnlig dialog med, og behandling af, virksomhedens utilfredse og klagende kunder. Informationsmateriale herom kunne udarbejdes.

\footnotetext{
${ }^{27}$ Quality management -- Customer satisfaction -- Guidelines for complaints handling in organizations
} 


\section{English Summary}

\subsection{Background of the report}

This report has been commissioned by Forbrugerstyrelsen (Consumer Affairs in Denmark) and financed by Nordisk Ministerråd (Nordic Council of Ministers).

The background for this report is that from the 1970s onwards the public sector has been receiving an increasing number of consumer complaints about businesses. This has occurred despite an allocation of resources within the public sector to establish, develop and improve decisions between consumers and businesses.

Thus, the public sector wishes to focus on yet another aspect to improve the contact and dialogue between consumers and the business world, i.e. the companies' own complaint management. In addition, via dialogue with companies and industries, the public sector wishes to contribute to, support and cultivate companies' responsibility for the management of their own consumer complaints, so that in future far more complaints may be solved directly between the business and the consumer.

As such, the project invites an incorporation of consumer policy as a part of the business development. Systematic complaint management in companies is an initiative that will benefit both the consumers, as they will experience improved service and quality, and the companies, as they will experience an improved relationship to their customers.

\subsection{Purpose of the report}

The report should contribute to the consumer authorities gaining better insight and knowledge into the extent of and methods for the management of consumer complaints in the companies, which may serve as a point of departure for possible solutions for the management of the increasing number of consumer complaints.

In concrete terms, this report aims to analyse how and to which extent Nordic (Sweden and Denmark have been chosen as cases) companies use complaint management systems. In this connection, the aim is also to initially determine conditions such as the companies' perceived gain (e.g. financial) from introducing complaint management systems.

The report's target group is public servants and politicians working with innovation and improvement of the consumer policy, as well as 
company managers and industrial organisations wishing to improve their efforts to strengthen customer satisfaction.

\subsection{Method of the report}

So far, complaint management as a discipline has not received any greater scientific attention in Denmark. The reason might be that the term is confused with 'complaint reception' and complaint handling', a part of 'complaint management', which viewed in isolation and on the surface would seem to include more trivial problems. Complaint handling deals with conditions such as the physical placement of e.g. complaint mail boxes, information to customers about complaint procedures, compensation etc. Complaint management deals more broadly with how you use complaint information in quality development and competitive situations, for example through the implementation of a complaint orientated culture in the company. The subject in this report is thus 'complaint management'.

The results of the report are based on a quantitative survey, using online questionnaires of 4 industries (furniture, groceries, electronics, cars) in two Nordic countries (Sweden and Denmark). The industries have been chosen based on the wish for a general creation of attention for complaint management systems among companies in society. Further, the industries have been chosen based on the fact that together they cover both short and long term consumption goods, low and high technological consumption goods as well as high and low priced consumption goods.

The used questionnaire is based on studies of international theoretical and empirical survey results within the area complaint management. The literature studies include both scientific articles and manuals and standards found in the industries or public sector. Even though the theoretical field still seems to be in a pre-paradigmatic stage, we believe to have identified and used relevant, adequate and consensual dimensions within the area.

\subsection{Results}

Among the surveyed companies, complaint management is only perceived as a strategic tool to a limited degree, just as companies' complaint management generally is not based on written policies that specify procedures etc. for the management of complaints. In spite of this, complaint management is a topic that top managements deal with on a daily basis to some extent.

Companies do not contest that complaining customers possess important information and that complaint management procedures would also 
provide the company with an image of humanity. Companies that have implemented complaint management procedures in particular emphasise that investment in complaint management systems are worthwhile.

We can also conclude that the companies seemingly provide contrasting information regarding how big a proportion of their customers are dissatisfied and the extent to which their customers express their dissatisfaction by complaining. Thus, on average the companies feel that they have both fewer dissatisfied and complaining customers compared to the respective industries as a whole. That is, they either underestimate the number of their own dissatisfied/complaining customers, or they overestimate the number of dissatisfied/complaining customers in relation to other companies.

It is also interesting that top management is most inclined to involve themselves in the daily complaint management in companies where complaint management is viewed as a strategic tool and where policies have been established to specify complaint management procedures etc. One possible explanation may be that in these companies, complaint management constitutes a collective focus area for the company. Thus companies with a strategic view of complaint management have established different complaint management initiatives to a greater extent than companies that only in part perceive complaint management as a strategic tool. However, the survey also shows that the companies (viewed as a whole) only to a limited degree have allocated resources to complaint management activities and that furthermore they only to a limited degree focus on interpersonal competences when they recruit new employees.

Companies that perceive complaint management as a strategic tool and that explicitly have specified procedures etc. for complaint management do not have a better a better business position (measured on the degree of profit) compared to companies that only to a limited degree share this view of complaint management.

\section{Strategic and political view of complaint management}

- Generally, the companies do not view complaint management as a strategic tool, just as written policies specifying procedures etc. for complaint management are not prevalent either. This is true for both countries and for all the surveyed industries.

- Top management gets somewhat involved in the companies' daily complaint management. This involvement only to a limited degree rests on a structural basis - and we may thus assume that daily ad hoc operations take place.

- On average the companies attach medium importance to the notion that investment in complaint management is worthwhile. Industries that generally have written policies for complaint management or where top management is most often involved in the complaint 
management attach the greatest importance to investment in complaint management.

- Companies with a structured (strategic and political) view of complaint management are generally larger (turnover and/or number of employees) than companies with a less structured view.

- Danish companies with a structured (strategic and political) view of complaint management experience greater customer dissatisfaction than companies with a less structured view.

The extent of dissatisfied customers for companies

- The average picture of the companies' estimates is that only a very small minority (less than 2\%) of customers have been dissatisfied with the company's products/services, dissatisfied with information/advice from the company or have been dissatisfied with the company for other reasons. There are only very few differences across industries when it comes to these three aspects of dissatisfaction.

- Across all industries - in both countries - a greater percentage of customers have expressed satisfaction with the surveyed companies compared to the percentage that has expressed dissatisfaction.

- On average, the companies (in both countries) feel that they have fewer dissatisfied customers compared to the industry as a whole and similarly that they have fewer complaining customers compared to the industry as a whole.

- In as much as it is assumed that the surveyed companies for the individual industries represent a correct picture of the population of companies, the result would indicate that the companies either overestimate the number of dissatisfied/complaining customers in the individual industries and/or underestimate the extent of the company's own dissatisfied/complaining customers.

The companies' view of complaining customers

- All companies, in both countries, only to a limited degree feel that complaining customers are difficult customers, that complaining customers represent a financial cost, that complaining customers are detrimental to the working environment, and that complaining customers are a psychological strain.

- To some degree, the companies feel that complaining customers possess important information.

- In both countries, the companies more or less agree that complaints are only partly due to the companies having provided the customer with incomplete or incorrect information, that the customer had unrealistic expectations of the information from the company or that the customer had unrealistic expectations of the company's product.

- In both countries the furniture retailers estimate that customer complaints are mainly due to faulty products. 
The companies' view of consequences of customer dissatisfaction

- The companies generally agree that dissatisfied customers to some or a greater extent could result in a bad reputation for the individual company. In Denmark car dealers especially share this estimate, while there are no statistical differences between the Swedish companies for this question.

- Both Danish and Swedish companies are to some extent concerned that dissatisfied customers may lead to a loss of market share. Here, the Danish car dealers are also the most concerned, however no differences can be shown between the Swedish companies.

- The more the companies experience customer dissatisfaction, the more the companies will experience negative consequences of customer dissatisfaction.

Complaint encouragement in the companies

- In Sweden, the extent of complaint encouragement is greater than in Denmark.

- In Denmark, the furniture industry is distinguished by representing the main part of the complaint encouragement initiatives, more so than the other industries.

- Danish and Swedish companies generally attach little importance to the employment of complaint encouragement initiatives in managing complaints.

- The more Danish companies view complaint encouragement initiatives as important, the more Danish companies will - as a whole - be inclined to initiate such initiatives. This relation could not be shown for the Swedish companies in the survey.

\section{Interaction between company and customer}

- The companies all agree that only rarely do they operate with a 'standard confirmation' in cases where a written confirmation of receipt is sent out in response to a written complaint. However, only rarely does the confirmation include a time schedule or a review of the procedure for the complaint management.

- Whether or not the customer has been satisfied with the complaint management is only followed up on (via phone or in writing) to a limited extent.

- The more dissatisfied customers the companies have, the more inclined they will be to perceive complaining customers negatively (i.e. as difficult, as a financial and psychological strain etc.).

The contents of the companies' complaint management

- The general picture is that companies only to a limited degree have launched systematic complaint management initiatives (including education of internal staff in complaint management, external courses 
for staff in complaint management, central collection and surveillance of complaint information, employment of fixed policies for complaint management and a listing of clear specifications for complaint registration).

- In Sweden car dealers tend to have more complaint management than the other industries.

- Companies that have launched complaint management initiatives are generally larger (turnover and/or number of employees) than companies that have only launched such initiatives to a lesser extent.

\section{Results of the companies' complaint management}

- According to the companies, only few complaining customers are rejected regardless of whether the rejection is given without a reason or with a written or verbal reason. According to the companies, complaining customers are more often than not met with unconditional or partial acceptance.

- Some types of complaint compensation are widely used by companies (e.g. free repair or exchange of the product), while others are only used more sparsely (e.g. the awarding of a symbolic gift or overcompensation to the customer).

- Among the Danish as well as Swedish companies in the survey, a widespread practice is to award the customers compensation for what the customer was supposed to receive.

- The more the companies award the customers complaint compensation, the more customer satisfaction the companies will experience in both Denmark and Sweden.

\section{The companies' internal complaint culture}

- It is a widespread practice in both the Danish and Swedish companies that the employees - if they make mistakes - lose their bonuses or the like or that they are rewarded for any improvements.

- Actual reprimands in connection with mistakes are more widespread in Sweden than in Denmark.

The companies' relationship to the law and appeal/complaint boards

The companies' complaint management practices are not particularly characterised by decisions made in the appeal boards (DK) / complaint boards (S).

The companies only attach little importance to appeal and complaint boards' influence on the company's competence development regarding complaint management and quality development.

In general, the companies feel that their complaint management puts the customer in a slightly better, or somewhat better, situation compared to the guidelines dictated by law and legal practice. In Denmark, the gro- 
cers are particularly prone to this opinion, while in Sweden there is no difference between the individual industries on this question.

\subsection{Recommendations}

The following recommendations have partly been conducted on the basis of achieved results in this report, and partly by results and insight achieved through secondary literature (most of this is included in chapter 2 of the report).

- Generally, the companies seem to have little experience with the handling of complaints. Furthermore, the research on return on investment has been slender in these areas. However, one study shows, among other things, that in the banking business significant results in return on investment, in the handling of complaints, have been achieved, and that the conditions for competition in this area has an imperative role ${ }^{28}$. In order to determine if investment in the handling of complaints has an impact on companies' competitive position, and thus on the company's profitability, an investigation of the four branches' consumers is conducted. The investigation can, among other things, determine how and to what extent the customers' experiences in the handling of complaints in companies can have an influence on the customers' contentment, decisions about repurchase and development of any customer loyalty.

- The results in this report concerning, among other things, customer discontentedness are based on companies' own perceptions of this. Due to this, it would be of interest to look closer at: (a) if there is a gap between the customers' own perception of contentment and the companies' assertions of customers' satisfaction, and (b) if there is a connection between the satisfaction experienced by the customer and companies', for example, general perception of customers' complaints, changes caused by customer complaints, view on customers who complain, etc.

- The companies thoroughly agree that discontented customers will, more or less, result in a poor reputation and/or loss of market shares for the individual company. Furthermore, the results of the report indicate that a high level of compensation on customer complaints initiate a higher level of customer satisfaction as experienced by the companies. These recognitions can be used by the Nordic countries' consumer council authorities when preparing information material, discussion meetings, workshops, or other undertakings with the intention to improve the companies' views on customer complaints, im-

${ }^{28}$ Fornell, Claes; Wernerfelt, Birger (1988), A Model for Customer Complaint Management, Marketing Science. 
provements based on complaints, and compensation due to complaints, etc. Consequently, an improved communication between the demand of the market (consumer based) and the supply of the market (the companies). Such improved communication will be useful for the market process, and hence have a positive effect on society in general.

- The Nordic countries' consumer council authorities could seek to identify a number of 'best practice' companies, which have, to a significant extent, incorporated systems of handling complaints, and also have achieved good results herewith. Such 'best practice' companies will both serve as inspiration and as the icebreaker in relation to companies, which to a smaller extent use systematized handling of complaints. This work will also provide an opportunity for the preparation of guidelines on the handling of complaints with practical inspiration and experiences to supplement already existing guidelines, such as the instructions by Danish Standard and the ISOguidance 10002:2004 ${ }^{29}$.

- The companies' handling of complaints is only to a limited extent affected by decisions made in the board of appeal/complaints office. The Nordic countries' consumer council authorities could in this connection highlight the board of appeal/complaint offices' significance as assistance in relation to how companies can establish themselves best in the market with the intention of achieving a useful dialog with, and treatment of, the companies' dissatisfied and complaining customers. Information material on this could be prepared.

\footnotetext{
${ }^{29}$ Quality management -- Customer satisfaction -- Guidelines for complaints handling in organizations
} 


\section{Tiivistelmä}

\subsection{Raportin tausta}

Raportti on tehty Tanskan kuluttajaviranomaisen Forbrugerstyrelsenin pyynnöstä Pohjoismaiden ministerineuvoston toimiessa rahoittajana.

Perusteena on se, että viranomaiset ovat 1970-luvulta lähtien saaneet entistä enemmän yrityksiä koskevia valituksia. Kehitys on ollut tämänsuuntaista huolimatta siitä, että julkinen sektori on osoittanut resursseja kuluttajien ja yritysten välisen päätöksenteon aikaansaamiseen, kehittämiseen ja parantamiseen.

Julkisella sektorilla halutaan kiinnittää huomiota myös toiseen kuluttajien ja elinkeinoelämän välisiä yhteyksiä ja vuoropuhelua parantavaan seikkaan eli yritysten omiin valitusten käsittelyjärjestelmiin. Yritysten ja toimialojen kanssa käytävän vuoropuhelun avulla julkinen sektori pyrkii lisäksi osaltaan edistämään, tukemaan ja vahvistamaan yritysten vastuunottoa omien kuluttajavalitustensa käsittelystä. Tavoitteena on, että aiempaa huomattavasti useammat valitukset kyettäisiin ratkaisemaan suoraan yritysten ja kuluttajien välillä.

Raportti päätyy suosittamaan kuluttaja-asioihin liittyvien toimintatapojen liittämistä osaksi yritystoiminnan kehittämistä. Kuluttajat kokevat yrityksissä tapahtuvan valitusten järjestelmällisen käsittelyn hyödyt palvelun ja laadun parantumisena ja yritykset asiakassuhteiden parantumisena.

\subsection{Raportin tavoitteet}

Raportin tavoitteena on lisätä kuluttajaviranomaisten tietämystä ja tuntemusta siitä, missä määrin ja millä keinoin kuluttajavalituksia yrityksissä käsitellään, ja sillä tavoin tarjota mahdollisen lähtökohdan kasvavan kuluttajavalitusmäärän käsittelyä koskeville ratkaisuvaihtoehdoille.

Konkreettisena tavoitteena on analysoida, miten ja missä määrin valitusten käsittelyjärjestelmiä käytetään pohjoismaisissa yrityksissä. Tarkastelu rajattiin ruotsalaisiin ja tanskalaisiin yrityksiin. Tavoitteena on myös alustavasti määritellä vallitseva tilanne, muun muassa ne taloudelliset ja muut hyödyt, joita yrityksissä on havaittu valitusten käsittelyjärjestelmien käyttöönotosta.

Raportin kohderyhmänä ovat kuluttaja-asioiden uudistamisen ja kehittämisen parissa työskentelevät virkamiehet ja poliitikot sekä yritysjohtajat ja toimialajärjestöt, jotka haluavat tehostaa toimiaan asiakastyytyväisyyden lisäämiseksi. 


\subsection{Tutkimusmenetelmä}

Valitusten käsittely alana ei ole toistaiseksi saanut Tanskassa juurikaan tieteellistä huomiota osakseen. Syynä saattaa olla "valitusten käsittely" termin sekoittuminen "valitusten vastaanottoon" ja "valitusten hoitamiseen", jotka ovat osa sitä ja jotka erillisinä ja pintapuolisesti tarkasteltuina tuntuisivat sisältävän vähäpätöisempiä ongelmia. "Valitusten hoitamiseen" kuuluvat sellaiset asiat, kuten esim. asiakaspalautelaatikkojen fyysinen sijoittelu sekä valitusmenettelyistä, korvauksista jne. tiedottaminen asiakkaille. "Valitusten käsittelyssä" käsitellään laajemmin valitustietojen käyttöä laadun kehittämisessä ja kilpailutilanteissa, esim. omaksumalla valituslähtöinen yrityskulttuuri. Tässä tutkimusraportissa tarkastellaan siis "valitusten käsittelyä".

Tutkimustulokset perustuvat verkon välityksellä tehtyyn kvantitatiiviseen kyselyyn, jonka kohteena oli neljä toimialaa (huonekalukauppa, päivittäistavarakauppa, elektroniikkakauppa ja autokauppa) kahdessa Pohjoismaassa (Ruotsissa ja Tanskassa). Toimialojen valintaperusteena oli halu kiinnittää yleisesti yhteiskunnallista huomiota valitusten käsittelyjärjestelmiin yrityksissä. Toimialat valittiin lisäksi siten, että kokonaisuus kattaisi sekä lyhytikäiset että kestokulutushyödykkeet, matalaa ja korkeaa teknologiaa edustavat kulutushyödykkeet samoin kuin hinnaltaan kalliit ja edulliset kulutushyödykkeet.

Kyselyssä käytetty verkkolomake perustui valitusten käsittelystä saatuihin kansainvälisiin teoreettisiin ja empiirisiin tutkimustuloksiin. Kirjallisuustutkimus käsittää tieteellisten artikkeleiden lisäksi ko. toimialoilta tai viranomaisilta löytyviä käsikirjoja ja menettelyohjeita. Vaikka alueen teoriakenttä vaikuttaisi edelleen olevan esi-paradigmaattisessa vaiheessa, uskomme, että olemme tunnistaneet alueen merkitykselliset, riittävät ja yleisesti hyväksytyt ulottuvuudet sekä käyttäneet niitä.

\subsection{Tulokset}

Valitusten käsittely mielletään tutkimuksen kohdeyrityksissä strategiatyökaluksi vain rajallisesti. Vastaavasti valitusten käsittely yrityksissä ei yleensä perustu kirjallisiin toimintaohjeisiin, joissa valitusten käsittelymenettelyt jne. olisi määritelty. Siitä huolimatta valitusten käsittely on asia, johon ylin yritysjohto osallistuu jossain määrin päivittäin.

Yrityksissä ei kiistetä sitä, etteikö valittavilla asiakkailla olisi tärkeää tietoa ja etteikö valitusten käsittelymenettelyillä voitaisi luoda inhimillisempää yrityskuvaa. Valitusten käsittelymenettelyjä käyttöön ottaneet yritykset korostavat erityisesti valitusten käsittelyjärjestelmiin panostamisen kannattavuutta.

Lisäksi voidaan päätellä, että yritykset antavat ilmeisesti ristiriitaisia tietoja tyytymättömien asiakkaittensa osuudesta ja siitä, missä määrin 
asiakkaat tuovat julki tyytymättömyyttään valittamalla. Yritykset kokevat keskimäärin, että niillä on sekä tyytymättömiä että valittavia asiakkaita suhteellisesti vähemmän kuin toimialalla yleensä. Toisin sanoen yritykset joko aliarvioivat omien tyytymättömien/valittavien asiakkaidensa määrän tai yliarvioivat muiden yritysten vastaavat luvut.

Kiinnostavaa on myös, että ylin johto on halukkainta osallistumaan päivittäiseen valitusten käsittelyyn yrityksissä, joissa valitusten käsittely nähdään strategiatyökaluna ja joissa on olemassa toimintaohjeet, jotka määrittelevät valitusten käsittelymenettelyt jne. Yhtenä mahdollisena selityksenä saattaa olla, että tällaisissa yrityksissä valitusten käsittely muodostaa yhteisen painopistealueen. Siten valitusten käsittelyä strategisesti tarkastelevissa yrityksissä on otettu käyttöön erilaisia valitusten käsittelyyn liittyviä menetelmiä laajemmassa määrin kuin niissä yrityksissä, joissa valitusten käsittely mielletään vain osittain strategiatyökaluksi. Kuitenkin kyselytutkimus osoittaa myös, että yritykset ovat (kokonaisuutena tarkastellen) myöntäneet valitusten käsittelytoimiin vain rajallisesti resursseja ja että rekrytoitavien vuorovaikutustaitoihin kiinnitetään vain vähäistä huomiota.

Yritykset, joissa valitusten käsittely mielletään strategiatyökaluksi ja joilla on muun muassa tarkoin määritellyt valitusten käsittelymenettelyt, eivät ole sen paremmassa liiketoiminnallisessa asemassa (tuottoasteella mitattuna) kuin yritykset, jotka vain osittain suhtautuvat samalla tavoin valitusten käsittelyyn.

\section{Valitusten käsittely osana strategiaa ja toimintatapoja}

- Valitusten käsittelyä ei yrityksissä yleensä mielletä strategiatyökaluksi. Vastaavasti puuttuvat usein myös kirjalliset toimintaohjeet, joissa menettelyt jne. olisi määritelty. Tilanne on sama kummassakin maassa ja kaikilla tutkituilla toimialoilla.

- Ylin johto osallistuu jossain määrin valitusten päivittäiseen käsittelyyn yrityksissä. Tällaisella osallistumisella on vain rajallinen rakenteellinen perusta, joten voitaneen olettaa, että kyse on tilannekohtaisesta osallistumisesta.

- Keskimäärin yritykset pitävät jossakin määrin tärkeänä sitä, että valitusten käsittelyyn panostaminen kannattaa. Panostusta valitusten käsittelyyn pidetään tärkeimpänä niissä yrityksissä, joissa on kirjalliset toimintaohjeet tai joissa ylin yritysjohto osallistuu siihen eniten.

- Yritykset, joilla on jäsentynyt näkemys valitusten käsittelystä (osana strategiaa ja toimintatapoja), ovat yleensä suurempia (liikevaihdoltaan ja/tai henkilöstömäärältään) kuin yritykset, joissa on jäsentymättömämpi näkemys.

- Niissä tanskalaisyrityksissä, joilla on jäsentynyt näkemys valitusten käsittelystä (osana strategiaa ja toimintatapoja), asiakastyytymättömyys koetaan suuremmaksi kuin yrityksissä, joissa vallitsee jäsentymättömämpi näkemys. 


\section{Yritysten tyytymättömien asiakkaiden määrä}

- Yritysten omat arviot osoittavat keskimäärin, että vain häviävän pieni osa (alle $2 \%$ ) asiakkaista olisi ollut tyytymättömiä yrityksen tuotteisiin/palveluihin tai yrityksen antamaan informaatioon/neuvontaan tai muista syistä. Näiden kolmen tyytymättömyyden muodon suhteen toimialojen väliset erot olivat hyvin pieniä.

- Kaikilla toimialoilla molemmissa maissa tutkimuksessa mukana olleisiin yrityksiin tyytyväisyytensä ilmaisseiden asiakkaiden osuus oli suurempi kuin tyytymättömyytensä julki tuoneiden.

- Molempien maiden yrityksillä oli keskimäärin käsitys, että niillä oli vähemmän tyytymättömiä asiakkaita kuin toimialalla yleensä. Vastaavasti yrityksissä koettiin, että niillä oli vähemmän valittavia asiakkaita kuin toimialalla muutoin.

- Olettaen, että tutkimukseen eri toimialoilta valitut yritykset edustavat koko yrityskantaa, tulos viittaisi siihen, että yritykset joko yliarvioivat tyytymättömien/valittavien asiakkaiden määrän toimialallaan ja/tai aliarvioivat omien tyytymättömien/valittavien asiakkaidensa osuuden.

\section{Yritysten käsitykset valittavista asiakkaista}

- Kaikki yritykset molemmissa maissa kokevat vain rajallisessa määrin, että valittavat asiakkaat ovat asiakkaina hankalia, muodostavat menoerän, ovat työympäristölle haitaksi tai ovat henkisesti kuormittavia.

- Yrityksissä koetaan jossakin määrin, että valittavilla asiakkailla on hallussaan tärkeää tietoa.

- Kummassakin maassa yritykset ovat suhteellisen yhtä mieltä siitä, että valitukset johtuvat vain osittain siitä, että yritys on antanut asiakkaille puutteellista tai virheellistä tietoa tai että asiakkaalla on ollut epärealistisia odotuksia yrityksen antaman tiedon tai yrityksen tuotteen suhteen.

- Molemmissa maissa huonekalujen vähittäiskauppiaat arvioivat, että asiakkaiden valitukset johtuvat pääasiassa tuotteiden virheistä.

Yritysten käsitykset asiakastyytymättömyyden seurauksista

- Yritykset ovat yleisesti yhtä mieltä siitä, että tyytymättömät asiakkaat saattavat jossakin määrin tai huomattavasti vahingoittaa yrityksen mainetta. Tanskassa tätä mieltä ovat erityisesti autojen vähittäiskauppiaat, kun taas ruotsalaisyritysten välillä ei tämän seikan suhteen ilmennyt tilastollisia eroja.

- Sekä tanskalaiset että ruotsalaiset yritykset ovat jossakin määrin huolissaan siitä, että asiakastyytymättömyys voi johtaa markkinaosuuksien menetykseen. Huolestuneimpia ovat tanskalaiset autokauppiaat, mutta ruotsalaisyritysten välillä ei voitu osoittaa eroja. 
- Mitä enemmän yritykset kokevat asiakastyytymättömyyttä, sitä enemmän ne kokevat kielteisiä seurauksia asiakastyytymättömyydestä.

Valittamiseen kannustaminen yrityksissä

- Ruotsissa asiakkaita kannustetaan valittamaan enemmän kuin Tanskassa.

- Tanskassa huonekaluala erottautuu muista siinä, että se kannustaa asiakkaita valittamaan selvästi enemmän kuin muut toimialat.

- Tanskassa ja Ruotsissa yritykset kiinnittävät yleensä vain vähän huomiota valittamiseen kannustaviin toimiin osana valitusten käsittelyä.

- Mitä suuremman merkityksen tanskalaisyritykset antavat valittamiseen kannustaville toimille, sitä valmiimpia ne ovat kokonaisuutena ottaen toteuttamaan tällaisia järjestelyjä. Samaa vastaavuutta ei voitu havaita tutkituissa ruotsalaisyrityksissä.

Yrityksen ja asiakkaan välinen vuorovaikutus

- Kaikki yritykset ilmoittavat käyttävänsä vain harvoin "vakiomuotoisia vastaanottoilmoituksia" lähettäessään kirjallisen vahvistuksen kirjallisen valituksen vastaanottamisesta. Vahvistus sisältää kuitenkin vain harvoin määräajan tai selostuksen valitusten käsittelymenettelystä.

- Asiakkaiden tyytyväisyyttä valitusten käsittelyyn seurataan (soittamalla tai kirjoittamalla) vain rajallisessa määrin.

- Mitä enemmän yrityksellä on tyytymättömiä asiakkaita, sitä yleisemmin yrityksessä suhtaudutaan valittaviin asiakkaisiin kielteisesti (hankala; taloudellinen ja henkinen rasite jne.).

\section{Valitusten käsittelyn sisältö}

- Yleiskuvaksi muodostui, että yrityksissä on vain rajallisessa määrin toteutettu järjestelmällisiä valitusten käsittelyä koskevia toimia (mm. valitusten käsittelyyn liittyvää sisäistä henkilöstökoulutusta, valitusten käsittelyssä työskentelevän henkilöstön ulkoista kurssitusta, valitustietojen keskitettyä keruuta ja seurantaa, yhtenäisten toimintatapojen soveltamista valitusten käsittelyyn ja valituksen rekisteröimiseksi tarvittavien selkeiden ohjeiden laatimista).

- Ruotsissa autojen vähittäiskauppiaat käyttävät valitusten käsittelyä jonkin verran enemmän kuin muilla toimialoilla.

- Yritykset, joissa on ryhdytty valitusten käsittelytoimiin, ovat yleensä suurempia (liikevaihdoltaan ja/tai henkilöstömäärältään) kuin yritykset, joissa tällaisiin toimiin on ryhdytty vähäisemmässä määrin. 
Yritysten tulokset valitusten käsittelystä

- Yritysten mukaan vain harvoja asiakkaiden tekemiä valituksia olisi hylätty, eikä merkitystä ole sillä, tapahtuuko hylkääminen perustetta ilmoittamatta vai kirjallisesti tai suullisesti perustellen. Yritysten mukaan asiakkaiden vaatimuksiin suostutaan useimmiten ilman ehtoja tai osittain.

- Tietyn tyyppisiä korvauksia valituksen johdosta käytetään yrityksissä yleisesti (esim. tuotteen maksuton korjaus tai vaihtaminen), kun taas toisia käytetään harvemmin (esim. vähäisen lahjan tai ylikorvauksen antaminen asiakkaalle).

- Tutkituissa tanskalaisissa ja ruotsalaisissa yrityksissä on yleisenä käytäntönä antaa asiakkaalle korvausta siitä, mitä asiakkaan oletettiin saavan, asiakkaalle kuljetuksesta aiheutuneesta haitasta tai valittamiseen liittyvästä henkisestä rasituksesta.

- Mitä enemmän yritykset myöntävät asiakkailleen valituksista korvauksia, sitä tyytyväisemmiksi yritykset kokevat asiakkaansa sekä Tanskassa että Ruotsissa.

Yritysten sisäinen valituskulttuuri

- Sekä tanskalaisissa että ruotsalaisissa yrityksissä on yleisenä käytäntönä, että virheitä tehneet työntekijät menettävät bonuksiaan tai vastaavaa kun taas parannuksista palkitaan.

- Varsinaiset nuhteet virheiden johdosta ovat tavallisempia Ruotsissa kuin Tanskassa.

Yritysten suhde lainsäädäntöön ja kuluttajavalituselimiin

Kuluttajavalituksia käsittelevien Tanskan ja Ruotsin viranomaisten päätökset eivät mainittavasti ohjaa yritysten valitusten käsittelymenettelyjä.

Yrityksissä annetaan vain vähän merkitystä kuluttajavalituselinten vaikutukselle valitusten käsittelyyn ja laadun kehittämiseen liittyvän osaamisen kehittämisessä.

Yrityksissä koetaan yleisesti, että yritysten valitusten käsittely asettaa asiakkaat hieman tai jonkin verran parempaan asemaan verrattuna lainsäädännöstä ja oikeuskäytännöstä johtuviin edellytyksiin. Tanskassa tätä mieltä on erityisesti päivittäistavarakauppa, kun taas Ruotsissa ei tässä suhteessa esiinny toimialojen välisiä eroja.

\subsection{Suositukset}

Seuraavat suositukset perustuvat osittain tämän raportin tuloksiin, osittain muusta kirjallisuudesta peräisin oleviin tuloksiin ja tietoihin (ks. tarkemmin luku 2). 
- Yleisesti ottaen yrityksillä ei näyttäisi olevan kovinkaan paljon kokemuksia valitusten käsittelyjärjestelmistä, eikä niihin tehtyjen sijoitusten tuottavuutta myöskään ole tutkittu laajemmin. Erään selvityksen mukaan tällaiset järjestelmät ovat kuitenkin osoittautuneet kannattaviksi mm. pankkialalla, kun myös kilpailuolosuhteilla on oma merkityksensä. ${ }^{30}$ Sen selvittämiseksi, vaikuttaako valitusten käsittelyyn panostaminen yritysten kilpailuasemaan ja sitä kautta lopulta yritysten kannattavuuteen, voitaisiin tehdä erillinen tutkimus kyseisen neljän toimialan asiakkaista. Tutkimuksen avulla voitaisiin mm. selvittää, missä määrin asiakkaiden kokemukset valitusten käsittelystä yrityksissä ovat vaikuttaneet asiakastyytyväisyyteen, uusintaostojen määrään ja kanta-asiakassuhteen muodostumiseen.

- Raportissa esitetyt tulokset perustuvat mm. asiakastyytyväisyyden osalta yritysten omiin arvioihin. Tähän liittyen olisi kiinnostavaa tarkastella lähemmin a) onko asiakkaiden kokeman ja yritysten ilmoittaman asiakastyytyväisyyden välillä eroja b) vaikuttaako asiakkaiden kokema tyytyväisyys esimerkiksi yritysten yleisiin käsityksiin valittavista asiakkaista, valittamiseen kannustaviin toimenpiteisiin, mielipiteisiin valittavista asiakkaista jne.

- Yritykset olivat yleisesti sitä mieltä, että asiakkaiden tyytymättömyys saattaa kohtalaisessa tai suuremmassa määrin johtaa siihen, että yksittäisen yrityksen maine kärsii ja/tai yritys menettää markkinaosuuksiaan. Raportin tulokset viittaavat lisäksi siihen, että mitä suuremmassa määrin yritykset tarjoavat korvausta asiakkaille, sitä paremmaksi yritykset itse kokevat asiakastyytyväisyyden. Näitä havaintoja Pohjoismaiden kuluttajaviranomaiset voivat hyödyntää tiedotusaineiston valmistelussa, kokouksissa, työpajoissa tai muissa toimenpiteissä pyrkiessään parantamaan yritysten suhtautumista valittaviin asiakkaisiin sekä edistämään kannustavien valitusjärjestelmien ja korvausten käyttöä jne. Tällä tavoin voidaan parantaa markkinoiden kysyntäpuolen (kuluttajien) ja tarjontapuolen (yritysten) välistä viestintää. Parantunut viestintä puolestaan edistää markkinoiden toimivuutta ja hyödyttää siten myös koko yhteiskuntaa.

- Pohjoismaiden kuluttajaviranomaiset voisivat etsiä sellaisia hyviksi koettuja käytänteitä - ns. best practices - soveltavia yrityksiä, joissa käytetään yleisesti erilaisia valitusten käsittelyjärjestelmiä ja joissa näistä järjestelmistä on saatu hyviä kokemuksia. Nämä yritykset voisivat toimia innoittajina ja tienavaajina sellaisille yrityksille, joissa valitusten järjestelmällinen käsittely on vähäisempää. Tämän työn pohjalta voitaisiin lisäksi laatia valitusten käsittelyä koskevat käytännön neuvoja ja kokemuksia sisältävät ohjeet, jotka täydentäisivät jo

${ }^{30}$ Fornell, Claes; Wernerfelt, Birger (1988), A Model for Customer Complaint Management, Marketing Science 
olemassa olevia ohjeita, erityisesti Dansk Standardin laatimia sekä ISO 10002:2004-ohjetta: ${ }^{31}$.

- Erilaisten valituslautakuntien antamilla ratkaisuilla on vain vähäinen sija yritysten valitusten käsittelyssä. Pohjoismaiset kuluttajaviranomaiset voisivat tässä yhteydessä korostaa valituslautakuntien merkitystä yritysten apuna niiden mukautuessa markkinoihin ja pyrkiessä hyödylliseen vuoropuheluun tyytymättömien ja valittavien asiakkaiden kanssa sekä käsittelemään heitä parhaalla mahdollisella tavalla. Tästä asiasta voitaisiin laatia myös tiedotusaineistoa.

${ }^{31}$ Laadunhallinta. Asiakastyytyväisyys. Suuntaviivat asiakasvalitusten käsittelyyn organisaatios- 


\section{Yfirlit á íslensku}

\subsection{Forsaga skýrslunnar}

Skýrsla pessi var unnin að frumkvæði Neytendastofnunarinnar (Forbrugerstyrelsen) í Danmörku og hún var kostuð af Norræna ráðherraráðinu.

Ástæða pess að ráđist var í að gera skýrsluna er sú að alveg frá pví á áttunda áratugnum hafa hinu opinbera borist kvartanir í stöðugt auknum mæli vegna fyrirtækja. Petta hefur gerst prátt fyrir að hið opinbera hafi lagt fram fjármuni til að koma á úrskurðarferli milli neytenda og fyrirtækja, próa pað áfram og bæta.

Nú hyggst hið opinbera leggja áherslu á annan pátt pessara mála til að bæta samband og samskipti neytendanna og viðskiptageirans. Pað verður fólgið í pví að efla kvartanastjórnun fyrirtækjanna sjálfra. Að auki vill hið opinbera stuðla að pví, með umræðum við fyrirtæki og atvinnugreinar, að ábyrgð fyrirtækjanna sjálfra á kvartanastjórnun sinni styrkist og próist, svo að í framtíðinni verði pað miklu algengara en nú að fjallað sé um kvartanir og pær afgreiddar í beinum samskiptum fyrirtækja og neytenda.

Áætlunin gerir ráð fyrir að neytendamálin verði sampætt viðskiptapróun fyrirtækjanna. Kerfisbundin kvartanastjórnun innan fyrirtækjanna sjálfra mun í raun verða bæði neytendunum og fyrirtækjunum til hagsbóta, pví neytendurnir munu fá betri pjónustu og gæði og stjórnendur fyrirtækanna munu kunna að meta bætt samskipti við viðskiptavinina.

\subsection{Markmið skýrslunnar}

Skýrslan mun væntanlega verða til pess að yfirvöld neytendamála fái betri innsýn í og meiri pekkingu á umfangi kvartana og hvernig unnið er úr peim í fyrirtækjunum. Á peim grunni verður vonandi hægt að byggja lausnir sem duga gegn hinum aukna fjölda kvartana frá neytendum.

Í stuttu máli má segja að pessari skýrslu sé ætlað að greina hvernig, og í hve miklum mæli, norræn fyrirtæki (fyrirtæki í Danmörku og Svípjóð hafa verið valin sem dæmi) beita kvartanastjórnunarkerfum sínum til að leysa málin. Í pví sambandi er rétt að geta pess að pað er eitt af markmiðunum að greina strax í upphafi hvaða ávinning (t.d. fjárhagslegan) fyrirtækin telja sig hafa af pví að koma sér upp sérstökum kerfum fyrir kvartanastjórnun.

Skýrslan er ætluð opinberum starfsmönnum og stjórnmálamönnum sem leitast við að innleiða nýjungar í stefnumótun fyrir neytendamál og umbætur í peim efnum. Sömuleiðis er hún ætluð framkvæmdastjórum 
fyrirtækja og samtökum atvinnuveganna sem vilja standa sig betur í að bæta viðhorf viðskiptavinanna gagnvart peim.

\subsection{Aðferðin við gerð skýrslunnar}

Enn sem komið er hefur kerfisbundinni og vísindalegri kvartanastjórnun ekki verið gefinn mikill gaumur í Danmörku. •að gæti stafað af pví að pessu hugtaki sé ruglað saman við 'móttöku kvartana' eða 'kvartanameðferð', en peir pættir kvartanastjórnunar virðast ekki erfiðir viðfangs pegar peir eru skoðaðir lauslega eða einir sér. Með kvartanameðferð er átt við atriði eins og pað hvar móttökukössum fyrir útfyllt kvartanaeyðublöð er komið fyrir, hvernig á að koma kvörtunum á framfæri, hvernig bætur eru ákvarðaðar, og fleira pess háttar. Með kvartanastjórnun er átt við hvernig upplýsingar er felast í kvörtunum eru notaðar til að bæta pjónustu og framleiðslu og til að efla samkeppnishæfnina, til dæmis með pví að gefa öllu sem snýr að kvörtunum mikið vægi í daglegum rekstri. Umfjöllunarefni pessarar skýrslu er pví 'kvartanastjórnun'.

Niðurstöður skýrslunnar tengjast magntengdri könnun sem byggist á spurningalista á netinu sem beindist að fjórum atvinnugreinum (húsgagnaframleiðslu, smásöluverslun, rafeindaiðnaði og bílum) í tveimur Norðurlandanna (Svípjóð og Danmörku). Dessar atvinnugreinar voru valdar vegna pess að pörf var talin á að kvartanastjórnunarkerfum væri gefinn meiri gaumur í fyrirtækjum almennt. Ennfremur voru einmitt pessar atvinnugreinar valdar pví í sameiningu ná pær bæði yfir daglegar neysluvörur og neysluvörur sem hafa lengri líftíma, ennfremur er um að ræða háog lágtæknivörur svo og bæði dýrar og ódýrar vörur.

niðurstöðum fræðilegra og reynsluvísindalegra kannana á sviði kvartanastjórnunar. Rannsóknir á skráđu efni nádu yfir vísindalegar greinar, svo og handbækur og staðla, bæði úr atvinnulífinu og opinbera geiranum. Pótt hinn fræðilegi páttur virðist enn ekki kominn á vísindalegt stig, teljum við okkur hafa fundið og hagnýtt viðeigandi og fullnægjandi gögn sem ekki ríkir ágreiningur um, á pessu sviði.

\section{4 Árangurinn}

Í fyrirtækjunum sem athugunin náði til líta menn svo á að kvartanastjórnun hafi ekki nema takmarkað gildi sem sóknartæki, enda er hún að jafnaði ekki byggð á skráðum markmiðum með ferilslýsingum. Samt purfa margir yfirstjórnendur að sinna kvartanamálum svo að segja daglega.

Hjá fyrirtækjunum draga menn ekki í efa að viðskiptavinir sem kvarta búi yfir verðmætri vitneskju og að fyrirtæki sem koma sér upp ferlum til kvartanastjórnunar fái við pað hagstæða ímynd í hugum fólks. Hjá fyrir- 
tækum sem tekið hafa petta skref, að innleiða kerfi fyrir kvartanastjórnun, ber mönnum einmitt saman um að pað hafi svo sannarlega borgað sig.

Við getum einnig dregið pá ályktun að svo virðist sem fyrirtæki veiti misvísandi upplýsingar um pað hvert er hlutfall óánægðra viðskiptavina og hve algengt pað er að peir láti óánægju sína í ljós með pví að kvarta. Hjá fyrirtækjunum er sú skoðun algeng að hjá peim, hverju fyrir sig, séu færri óánægðir og kvartandi viðskiptavinir en í viðkomandi grein í heild. Samkvæmt pví er annaðhvort um pað að ræða að menn vanmeti fjölda óánægðra/kvartandi viðskiptavina sinna eða að peir ofmeti fjölda óánægðra/kvartandi viðskiptavina annarra fyrirtækja.

Einnig er eftirtektarvert að peir æðstu sjórnendur sem mestan áhuga hafa á að koma að daglegri umfjöllun um kvartanamál eru í fyrirtækjum par sem litið er á kvartanastjórnun sem áhrifamikið sóknartæki og jafnframt mótuð stefna fyrir meðhöndlun peirra mála. Hugsanlega er hægt að skýra petta pannig að í peim fyrirtækjum sé kvartanastjórnunin sameiginlegt áhersluatriði. Pannig hafa fyrirtæki, par sem litið er á kvartanastjórnun sem mikilvægt vopn til sóknar, komið á fjölbreyttari aðferðum við kvartanastjórnun heldur en pau fyrirtæki sem ekki hafa að fullu viðurkennt að kvartanastjórnun hafi mikla pýðingu í samkeppninni. Hins vegar sýnir könnunin einnig að fyrirtækin hafa (pegar á heildina er litið) einungis lagt fram tiltölulega lítið fjármagn til kvartanastjórnunar og jafnframt leggja pau fremur litla áherslu á samskiptafærni pegar pau ráða fólk til starfa.

Fyrirtæki sem líta svo á að kvartanastjórnun sé mikilvægt sóknartæki og hafa skipulagt vel afmörkuð ferli fyrir hana, eru ekki betur stödd (ef litið er á hagnaðartölur) heldur en pau fyrirtæki sem ekki hafa sama viðhorf til pessara mála nema að takmörkuðu leyti.

\section{Stjórnunarlegar hliðar kvartanastjórnunar og sóknarfceri er hún veitir}

- Almennt líta fyrirtækin ekki svo á að kvartanastjórnun veiti sérstök færi til framsóknar á markaði, enda er lítið um að skipulögð séu og skráð ferli fyrir pann pátt. betta á við um bæði löndin og allar atvinnugreinarnar sem skoðaðar voru.

- Æðstu stjórnendur fyrirtækjanna taka að einhverju leyti pátt í daglegri kvartanastjórnun peirra. Pátttaka stjórnendanna er pó einungis að takmörkuðu leyti skipulögð sem páttur í starfinu og pví má gera ráð fyrir að lausnir kvörtunarmála séu iðulega sérsniðnar eftir aðstæðum.

- Almennt má segja að fyrirtækin leggi ekki nema í meðallagi mikla áherslu á framlög til kvartanastjórnunar. Í greinum par sem almennt er stuðst við skráðar reglur um kvartanastjórnun eða par sem algengast er að yfirstjórnendur taki pátt í kvartanastjórnun er mest áhersla lögð á framlög til hennar.

- Fyrirtæki með vel afmörkuð og skipulögð viðhorf til kvartanastjórnunar (stjórnunarleg og með tilliti til framsóknar á markaði) eru 
venjulega stærri (meiri velta og/eða fleira starfsfólk) heldur en pau fyrirtæki par sem ekki ríkja eins próuð viðhorf til peirra mála.

- Hjá dönskum fyrirtækjum með vel afmörkuð og skipulögð viðhorf til kvartanastjórnunar (stjórnunarleg og með tilliti til framsóknar á markaði) er meira um óánægða viðskiptavini heldur en hjá fyrirtækjum par sem ekki ríkja eins próuð viðhorf til pessara mála.

\section{Fjöldi óáncegðra viðskiptavina eftir fyrirtcekjum}

- Algengast er að fyrirtækin haldi pví fram að einungis mjög lítill hluti (undir 2\%) viðskiptavinanna séu óánægðir með framleiðslu/pjónustu fyrirtækisins upplýsingar/ráðgjöf pess eða önnur atriði. Einungis er um að ræða minniháttar frávik frá pessu milli atvinnugreina í tengslum við pessa prjá flokka óánægju.

- Í öllum atvinnugreinunum - í báđum löndunum - eru peir viðskiptavinir fleiri sem láta í ljós ánægju með fyrirtækin sem voru til skoðunar heldur en peir sem láta í ljós óánægju.

- Almennt má segja að fyrirtækin (í báoum löndunum) álíti að pau hafi færri óánægða viðskiptavini heldur en tíðkast í viðkomandi grein í heild og jafnframt að færri viðskiptavinir peirra kvarti heldur en tíðkast í greininni í heild.

- Ef gert er ráð fyrir að fyrirtækin, sem voru til skoðunar, sýni rétta mynd af öllum fyrirtækjum í viðkomandi greinum, benda niðurstöðurnar til pess að fyrirtækin annaðhvort ofmeti fjölda óángðra/kvartandi viðskiptavina í viðkomandi greinum eða vanmeti fjölda óánægðra/kvartandi viðskiptavina sinna.

\section{Álit fyrirtcekjanna á viðskiptavinum sem kvarta}

- Í aðeins örfáum fyrirtækjum í báðum löndunum álíta menn að viðskiptavinir sem kvarta séu erfiðir, að peir séu fjárhagslegur baggi á fyrirtækjunum, að peir hafi slæm áhrif á vinnuumhverfið og að peir valdi slæmu sálfræðilegu álagi.

- Nokkuð er um pað að fyrirtæki álíti að viðskiptavinir sem kvarta búi yfir mikilsverðum upplýsingum.

- Í báđum löndunum eru fyrirtæki meira eða minna sammála um að kvartanir stafi einungis að litlu leyti af pví að veittar hafi verið ófullkomnar eða rangar upplýsingar. Sömuleiðis ber peim saman um að viðskiptavinurinn hafi verið með óraunhæfar væntingar í sambandi við upplýsingar frá fyrirtækinu, eða að hann hafi gert sér óraunhæfar hugmyndir um framleiðsluvörur pess.

- Í báðum löndunum álíta húsgagnasmásalar að kvartanir viðskiptavina stafi aðallega af framleiðslugöllum.

\section{Skoðanir fyrirtcekjanna á afleiðingum óáncegju viðskiptavina}

- I Í fyrirtækjunum eru menn almennt sammála um að óánægja viðskiptavina geti spillt að meira eða minna leyti pví orði sem fer af við- 
komandi fyrirtæki. Í Danmörku er áberandi hvað bílasalar eru almennt á pessari skoðun, en í Svípjóð var ekki hægt að sjá neinn staðtölulegan mun milli fyrirtækja hvað petta varðar.

- Bæði í dönskum og sænskum fyrirtækjum hafa menn nokkrar áhyggjur af pví að óánægðir viðskiptavinir minnki markaðshlutdeild. Danskir bílasalar hafa mestar áhyggjur af pessu atriði, en enginn munur er merkjanlegur milli sænsku fyrirtækjanna.

- Eftir pví sem óánægja viðskiptavina vex verða afleiðingarnar af pví verri fyrir viðkomandi fyrirtæki.

Viðskiptavinir hvattir til að benda á pað sem miður fer

- Í Svípjóð er meira um að kaupendur séu hvattir til að kvarta yfir pví sem miður fer.

- Í Danmörku er pað í húsgagnaiðnaðinum sem mest er um að kaupendur eru hvattir til að kvarta yfir pví sem miður fer

- Dönsk og sænsk fyrirtæki hafa að jafnaði litla trú á að gagnlegt sé að hvetja kaupendur til að kvarta og að gera pað að pætti í kvartanastjórnun fyrirtækjanna.

- Eftir pví sem pað færist í vöxt meðal danskra fyrirtækja að pað sé álitið mikilvægt að kaupendur séu hvattir til að kvarta yfir pví sem miður fer, eftir pví verða dönsk fyrirtæki, pegar á heildina er litið, líklegri til að taka upp slíka hætti. Ekki varð vart við pessa tilhneigingu hjá sænskum fyrirtækjum í könnuninni.

Samskipti fyrirtcekis og viðskiptavinar

- Fyrirtækin eru öll sammála um að pað komi ekki oft fyrir að pau sendi út 'staðlaðar móttökustaðfestingar' sem svör við skriflegum kvörtunum.

раð gerist tiltölulega sjaldan að kvörtunarmáli sé fylgt eftir og kannað (með símtali eða skriflega) hvort viðskiptavinurinn hefur verið ánægður með úrlausnina.

- Eftir pví sem fleiri eru óánægðir með pjónustu tiltekins fyrirtækis eru meiri líkur á að peir sem par vinna séu neikvæðir gagnvart peim sem kvarta (halda pví fram t.d. að peir séu erfiðir, séu fjárhagslegur baggi á fyrirtækinu, valdi sálarlegu álagi).

\section{Í hverju er kvartanastjórnun fyrirtcekanna fólgin?}

- Fæst fyrirtæki hafa komið á hjá sér kerfisbundinni kvartanastjórnun (par með talin tilsögn í kvartanastjórnun fyrir starfsfólkið innan fyrirtækisins og námskeiðum fyrir pað utan pess, söfnun upplýsinga um kvartanamál og eftirlit með peim á einum stað, beiting fastákveðinna reglna fyrir kvartanastjórnun, svo og skrá með greinilegum fyrirmælum fyrir kvartanaskráningu).

- Í Svíbjóð er kvartanastjórnun algengari hjá bílasölum en í hinum atvinnugreinunum. 
- Fyrirtæki sem hafa komið á hjá sér kerfisbundinni kvartanastjórnun eru yfirleitt stærri (meiri velta og/eða fleira starfsfólk) heldur en fyrirtæki sem síður hafa tekið upp slíka starfsemi.

\section{Árangur kvartanastjórnunar fyrirtoekjanna}

- Samkvæmt pví sem fyrirtækin halda fram, gerist pað sjaldan að kvörtunum sé vísað á bug, óháð pví hvort ástæður höfnunar séu tilgreindar eða ekki. Fyrirtækin staðhæfa ennfremur að kvartanir séu oftast viðurkenndar án skilyrða.

- Vissar aðferðir við að bæta fyrir bað sem kvartað er yfir eru mikið notaðar af fyrirtækjunum (t.d. ókeypis viðgerðir eða pað að skipt er um hlutinn), en aðrar aðferðir eru miklu síður notaðar (t.d. táknrænar gjafir eða umframbætur)

- I Í dönskum jafnt sem sænskum fyrirtækjum sem skoðuð voru er pað afar algengt að kaupandanum sé bætt pað sem álitið er að hann hafi átt að fá í upphafi, að viðbættri fyrirhöfn hans vegna flutninga eða fyrir sálrænt álag sem fylgir pví að kvarta.

- Eftir bví sem fyrirtækin koma betur á móts við viðskiptavini sem kvarta, pví ánægðari eru peir með frammistöðu peirra. betta gildir jafnt í Danmörku og Svípjóð.

Hvernig er tekið á pvi sem miður fer hjá starfsfólkinu?

- að er mjög útbreiddur siður, bæði í dönskum og sænskum fyrirtækjum að starfsfólk missir bónusa eða annað af pví tagi, ef pví verður á mistök, eða að pví er umbunað fyrir framfarir í starfi.

- Meira er um pað í Svípjóð en í Danmörku að starfsfólk sé ávítað ef pví verður eitthvað á í vinnunni.

Viðhorf fyrirtcekjanna til laga og áfrýjunar- eða kvörtunarnefnda

Ekki er hægt að segja að aðferðir við kvartanastjórnun einkennist mikið af ákvörðunum sem teknar eru af áfrýjunarnefndum (í Danmörku) eða kvartananefndum (í Svíbjóð).

Fyrirtækin gera lítið úr pví að störf áfrýjunar- og kvartananefnda efli framfarir hvað varðar kvartanastjórnun og gæðapróun.

Almennt álíta fyrirtækin að kvartanastjórnun peirra bæti aðstöðu viðskiptavinanna lítið eitt eða rúmlega pað, borið saman við pær leiðbeinandi reglur sem felast í lögum og lagavenjum. Í Danmörku er pessi skoðun sérstaklega áberandi hjá matvörukaupmönnum en í Svíbjóð er enginn munur hvað petta varðar milli atvinnugreina.

\subsection{Tillögur}

Eftirfarandi tillögur hafa að hluta til verið unnar út frá pví sem áunnist hefur með pessari skýrslu, en að nokkru leyti út frá árangri og skilningi á 
vandamálunum sem náðst hefur og fengist hefur við lestur annars efnis (sem er mestallt tekið með í 2. kafla skýrslunnar).

- Almennt má segja að fyrirtækin hafi litla reynslu í meðhöndlun kvartana. Auk pess hefur lítið verið rannsakað hvað peir fjármunir, sem varið hefur verið til pessa málaflokks, hafa gefið af sér. Að vísu sýnir ein könnun pað, meðal annars, að fjárframlög bankageirans til meðhöndlunar kvartana hafa gefið vel af sér, og ennfremur að pað skiptir verulegu máli hvaða skilyrði samkeppnin býr við á pví sviði ${ }^{32}$. Til að sjá hvort framlög til kvartanameðhöndlunar hefur áhrif á samkeppnisstöðu fyrirtækja, og par með á arðsemi peirra, hefur verið farið út í athugun á viðskiptavinum atvinnugreinanna fjögurra. Мeð pessari könnun er hægt, meðal annars, að sjá hvernig og að hve miklu leyti reynsla viðskiptavinanna af kvartanameðhöndlun fyrirtækjanna ræður pví hvort peir eru ánægðir með viðskiptin, hvort peir versla aftur við fyrirtækin, og hvort peir halda tryggð við pau.

- аð sem kemur fram í skýrslunni, meðal annars um óánægju viðskiptavina, byggist á pví hvernig fyrirtækin upplifa pessa hluti. Af pessum ástæðum gæti verið áhugavert að rannsaka nánar (a) hvort einhver munur er á bví hvernig annars vegar viðskiptavinirnir og hins vegar fyrirtækin skynja pessa hluti, og (b) hvort eitthvert samband er á milli peirrar ánægju sem viðskiptavinirnir upplifa og, svo að dæmi sé tekið, pess hvaða augum fyrirtækin líta kvartanirnar, svo og peirra breytinga sem verða vegna kvartana, og viðhorfa til viðskiptavina sem kvarta, og pannig áfram.

- Deir sem stýra fyrirtækjunum eru alveg sammála um að óánægðir viðskiptavinir skaði orðspor peirra og/eða dragi úr markaðshlutdeildinni. Ennfremur gefa niðurstöður skýrslunnar til kynna að pað sé álit fyrirtækjanna að rausnarlegar bætur vegna kvartana auki mjög ánægju viðskiptavina. Pessar niðurstöður geta yfirvöld neytendamála á Norðurlöndunum hagnýtt við samningu upplýsingaefnis, á umræðufundum, í "smiðjum" eða við önnur tækifæri, til að bæta viðhorf fyrirtækjanna til kvartana viðskiptavinanna, til endurbóta sem koma til vegna kvartana og til bóta vegan kvartana, og pannig áfram. Petta gæti leitt til bættra samskipta milli krafna markaðarins (sem neytendur setja fram) og framboðs á markaði (á vegum fyrirtækjanna). Slíkar endurbætur á samskiptum efla markaðsferlin mikið og hafa af peim sökum jákvæð áhrif á samfélagið í heild.

- Yfirvöld neytendamála á Norðurlöndum purfa að leita uppi allnokkur "Fyrirmyndarfyrirtæki" sem komið hafa upp velheppnuðum kerfum til að meðhöndla kvartanir. Slík "fyrirmyndarfyrirtæki” verða öðrum fyrirtækjum góð fyrirmynd og brjóta ísinn í samskiptum við önnur fyrirtæki sem ekki eru eins langt komin í pví að fella

${ }^{32}$ Fornell, Claes; Wernerfelt, Birger (1988), A Model for Customer Complaint Management, Marketing Science. 
kvartanameðhöndlun í kerfi. Pessi vinna mun einnig veita mönnum tækifæri til að útbúa leiðbeinandi reglur um meðhöndlun kvartana með hagnýtri nálgun og hagnýtingu mikilvægrar reynslu í pví skyni að bæta við viðmiðunarreglur sem pegar eru fyrir hendi, eins og t.d. leiðbeiningar Danish Standard og ISO-leiðbeiningar 10002:2004 ${ }^{33}$

- Kvartanameðhöndlun fyrirtækjanna verður einungis að takmörkuðu leyti rakin til ákvarðana sem teknar eru af áfrýjunarnefndum eða kvartanaskrifstofum. Yfirvöld neytendamála á Norðurlöndum gætu í pessu samhengi lagt áherslu á mikilvægi áfrýjunarnefnda eða kvartanaskrifstofa, pví pær gætu leiðbeint fyrirtækjum um hvernig pau geta komið sér sem best fyrir á markaðnum til að koma á gagnlegum samskiptum við óánægða viðskiptavini sína og bregðast við kvörtunum peirra á farsællegan hátt. Hægt væri að útbúa kynningarefni um pessi mál.

${ }^{33}$ Gæðastýring - Ánægðir viðskiptavinir - Leiðbeinandi reglur um kvartanameðhöndlun í fyrir- 


\section{Appendix A}

Har været utilfredse med virks. produkter/ydelser

Har været utilfredse med virks. informationsafgivning og/el. rådgivning

Har været utilfredse med virks. af anden årsag

OVERORDNET SYN PÅ KLAGEBEHANDLING

a. Klagebehandling opfattes som et strategisk værktøj

b. Virks. klagebehandling er baseret på skriftligt formulerede politikker, som specificerer procedurer mv. for virks. klagebehandling

OPFATTEDE (NEGATIVE) KONSEKVENSER AF KUNDEUTILFREDSHED
a. Vi mister markedsandel
b. Vi skal ofre ressourcer på klagebehandling
c. Vi får dårligt omdømme

KONKRET (NEGATIVT) SYN PÅ KLAGENDE KUNDER $0.72 / 0.78$
a. Klagende kunder er besværlige kunder
b. Klagende kunder er en økonomisk omkostning
c. Klagende kunder er ødelæggende for arbejdsklimaet
d. Klagende kunder er psykisk belastende

* Reliabilitetskoefficienten, Cronbachs alpha, varierer fra $0-1$, hvor værdier $>0.60$ 0.70 er udtryk for tilfredsstillende reliabilitet. 



\section{Appendix B}

\section{OPLEVET KUNDEUTILFREDSHED}

c. Har været utilfredse med virks. produkter/ydelser

d. Har været utilfredse med virks. informationsafgivning og/el. rådgivning

e. Har været utilfredse med virks. af anden årsag

\section{KOMPENSATION}

$0.89 / 0.76$

a. Produktet byttes og kunden modtager en stor gave el.lign. for ulejligheden

b. Vi kompenserer kunden for det besvær, det har været f.eks. at skulle transportere sig ekstraordinært til virksomheden som følge af en fejl

c. Vi kompenserer kunden for den psykiske anstrengelse det kan være at klage

d. Vi 'overkompenserer' kunden for at gøre kunden opmærksom på, at vi sætter pris på, at kunden har tilkendegivet sin utilfredshed

\section{FAKTISK KLAGEOPFORDRING}

$0.97 / 0.96$
a. Iøjnefaldende opslag i butikker og kontorer
b. Tydelige og fremhrevede indrykninger i kataloger
c. Henvisninger $\mathrm{i}$ litteratur og instruktionsbøger
d. Meddelelser på fakturaer, regninger, ordresedler og kvitteringer
e. Notitser på web-sider
f. Tilbud om deltagelse i lodtrækning
g. Opsætning af fysiske klagebrevkasser
h. Opsætning af fysiske klagebrevkasser
i. Annoncering /information om klageadgang i brochurer el.lign.

* Reliabilitetskoefficienten, Cronbachs alpha, varierer fra 0-1, hvor værdier $>0.60$ 0.70 er udtryk for tilfredsstillende reliabilitet. 